Discussion Paper No. 10-044

\title{
Understanding the Competitiveness Implications of Future Phases of EU ETS on the Industrial Sectors
}

Ulrich Oberndorfer, Victoria Alexeeva-Talebi, and Andreas Löschel

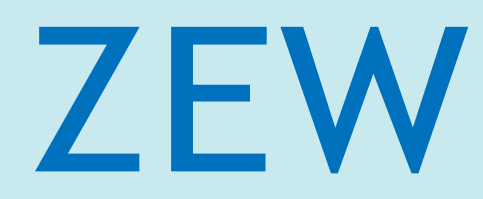

Zentrum für Europäische Wirtschaftsforschung $\mathrm{GmbH}$ Centre for European Economic Research 
Discussion Paper No. 10-044

\title{
Understanding the Competitiveness Implications of Future Phases of EU ETS on the Industrial Sectors
}

\author{
Ulrich Oberndorfer, Victoria Alexeeva-Talebi, \\ and Andreas Löschel
}

Download this ZEW Discussion Paper from our ftp server:

ftp://ftp.zew.de/pub/zew-docs/dp/dp10044.pdf

Die Discussion Papers dienen einer möglichst schnellen Verbreitung von neueren Forschungsarbeiten des ZEW. Die Beiträge liegen in alleiniger Verantwortung der Autoren und stellen nicht notwendigerweise die Meinung des ZEW dar.

Discussion Papers are intended to make results of ZEW research promptly available to other economists in order to encourage discussion and suggestions for revisions. The authors are solely responsible for the contents which do not necessarily represent the opinion of the ZEW. 


\section{Non technical summary}

Drawing on specific examples from products and subsectors within the EU ETS, this paper empirically tests to what extent those sectors are able to adjust their output prices when facing an input price change. The pass-through ability of sectors with respect to country- or regionspecific input prices should serve as an indication of the pass-through ability of carbon costs by firms. While the focus of the study lies on estimating pass-through relationships in selected sectors of the UK economy, the advanced econometric methods, particularly related to the asymmetric price transmission, are applied. The latter means the ability of producers to differently pass on positive and negative input price shocks to the consumers. Our results provide new insights into the debate on the ability of pass-through of costs generated by the EU Emissions Trading Scheme. They show that the UK sectors are not capable to completely pass-through their costs into output prices, with the exception of UK ceramic goods.

\section{Das Wichtigste in Kürze}

Die vorliegende Arbeit untersucht - anhand von spezifischen Beispielen an Produkten und Sektoren innerhalb des EU-EHS - empirisch, in wieweit die betrachteten britischen Sektoren in der Lage sind, ihre Outputpreise anzupassen, wenn sich die Inputpreise ändern. Die Möglichkeiten zur Überwälzung länder- oder regionenspezifischer Inputpreise sollen Aufschluss über die Überwälzungspotentiale für CO2-Kosten der Unternehmen geben. Der Fokus der Arbeit liegt auf der Schätzung von Überwälzungsbeziehungen in ausgewählten Sektoren. Es werden moderne ökonometrische Ansätze verwendet, die zur Analyse asymmetrischer Preisweitergabe Anwendung finden. Hierbei wird untersucht, ob Produzenten positive bzw. negative Inputpreisschocks in unterschiedlicher Höhe an die Konsumenten weitergeben. Die Ergebnisse dieser Arbeit zeigen, dass einige der analysierten Sektoren in der Lage sind, einen Teil ihrer $\mathrm{CO}_{2}$-Kosten an den Endkunden weiterzugeben. Jedoch können nicht alle Kosten vollständig an den Verbraucher weitergegeben werden. Eine Ausnahme bildet hier ein Teil der britischen Keramikindustrie. 


\title{
Understanding the competitiveness implications of future phases of EU ETS on the industrial sectors
}

\author{
Ulrich Oberndorfer*, Victoria Alexeeva-Talebi** and Andreas Löschel** \\ * Federal Ministry of Economics and Technology, Scharnhorststr. 34-37, 10115 Berlin, \\ Germany \\ ** Centre for European Economic Research (ZEW), \\ P.O. Box 1034 43, 68034 Mannheim, Germany
}

E-mails: ulrich.oberndorfer@bmwi.bund.de, alexeeva-talebi@zew.de, loeschel@zew.de

\begin{abstract}
In making key decisions for the future phases of the European Union Emissions Trading Scheme (EU ETS), policy makers need to fully understand the competitiveness implications of these decisions on industrial sectors. In this paper, we conduct an empirical analysis of cost pass-through ability of producers of selected products within the sectors refineries, glass, chemicals and ceramics of the UK economy. Our results provide new insights into the debate on the ability of pass-through of costs generated by the EU ETS. They suggest that some of the sectors analysed have the ability to pass-through a portion of their carbon costs to the consumers: The UK sectors are not capable to completely pass-through their costs into output prices, with the exception of UK ceramic goods.
\end{abstract}

JEL Classification: C22, D40, H23

Keywords: Emissions Trading, Competitiveness, Cost Pass-Through

Acknowledgements: The authors are grateful to Graham Boyd and Annie Norgrove for valuable comments and contributions. Funding by the Department for Business Enterprise and Regulatory Reform (now Department for Business, Innovation and Skills) is gratefully acknowledged. The ideas expressed here remain those of the authors who remain solely responsible for errors and omissions. They do not reflect the positions of the institutions they are affiliated with. 


\section{Introduction}

In making key decisions for future phases of the European Union Emissions Trading Scheme (EU ETS), policy makers need to fully understand the competitiveness implications of these decisions on industrial sectors. There is some literature in this field, such as that by McKinsey, Vivid Economics, Climate Strategies, Oxford Economics and others. This paper seeks to build on that and explore gaps in the existing knowledge base. In particular, it should enable policy makers to expand their understanding with respect to the ability of firms to pass through costs especially those related to a price for carbon. A robust empirical analysis has been designed to draw conclusions on sectoral competitiveness implications associated with cost pass-through.

Generally speaking, the potential exposure level of industries or sectors to EU ETS can be assessed through three major factors: The $\mathrm{CO}_{2}$ intensity of production, the opportunity to abate carbon within the sector, and the ability to pass along carbon cost increases through to output prices. The economic impacts of the EU ETS scheme hinges to a certain extent on whether carbon costs are reflected in output prices, although the overall emission cap is of preeminent importance in achieving lower emissions.

Under conditions approximating textbook perfect competition, one would expect a 100 percent or full cost pass through to occur, since there is no surplus to draw upon and costs have no where to go but into output prices. In real world market conditions of less than perfect competition, the ability and behaviour of firms in passing through costs is an important question worthy of empirical study.

From a theoretical point of view, within the EU ETS, the incentives for pass-through, and other firm pricing behaviour, should not differ between emissions trading schemes where grandfathering or auctioning are used as a method of allocation. Generally, the choice between those two options rather refers to distributional than to efficiency issues, relating to the question whether revenues should remain with covered industries or with the regulator. In the latter case, the government has the option to redistribute auctioning revenues.

However, while decisions on the margin will not be affected by the method of allocating carbon permits, be it free allowances or auctioning, the level of profitability of firms will be impacted. For example, if a multinational company has sites in non-carbon constrained 
regions, they may divert their production or new investments in plant capacities towards the non- carbon constrained regions as anticipated profits will be higher.

In this paper, we conduct an empirical analysis of the cost pass-through ability of producers of selected products within the sectors refineries, glass, chemicals and ceramics. This means that we empirically test whether, and to what extent, those sectors are able to adjust their output prices when facing an input price change.

For the purpose of analysing actual pass-through of carbon costs, the availability of weekly data on sectoral output prices is highly desirable. This is due to the fact that the EU ETS is still in an early stage and time series for carbon prices are therefore of relatively short duration if less frequent data is used. As weekly output price data is only available for two products of those analysed, namely diesel and gasoline, we can directly assess carbon cost pass-through only for those products of the UK oil industry. For the selected products of glass, chemicals and ceramics sectors, pass-through analysis is only possible for costs other than carbon costs. The ability to pass through such costs should serve as a proxy for (or indication of) the ability to pass through carbon costs. Inputs have been chosen in order to reflect the relevant cost variables of the industries analysed. The methodology that has been deployed to identify variables that could serve as a proxy for carbon costs has focussed on selecting country specific cost shocks. In a world with asymmetric and variable carbon constrains, carbon costs are correctly viewed as country-specific costs.

In summary, the pass-through ability of sectors with respect to country- or region-specific input prices should serve as an indication of the pass-through ability of carbon costs by firms. While the focus of the study is on estimating pass-through relationships in selected sectors, the advanced methods particularly related to analysis of the asymmetric price transmissions are applied. The phenomenon of asymmetric price transmission is often referred to in the following terms: Producers immediately pass through cost increases to the consumers. In contrast, cost decreases are passed through only with delay, if at all. Hence, asymmetric price transmission is directly related to the ability of producers to differently pass on positive and negative input price shocks to the consumers. Although this phenomenon is often associated with the market power of the respective producer, there are further theoretical explanations of asymmetric cost pass-through ability. The latter include menu costs as well as accountancy rules and inventory valuation. 
Our results provide new insights into the debate on the ability of pass-through of costs generated by the EU Emission Trading Scheme. They suggest that some of the sectors analysed have the ability to pass through a portion part of their carbon costs to the consumers. However, our results indicate that the sectors are not capable to completely pass-through their costs into output prices, with the exception of ceramic goods.

This paper is organised as follows: Chapter 2 discusses the data issues. In Chapter 3, we present the methodology and in chapter 4 our results. Chapter 5 concludes. 


\section{Data}

For the analyses presented in this paper, different data sets are used. The first one is of weekly frequency and roughly covers the first phase of the EU ETS (see Figure 1 for a plot of selected series from this data set). This is used to analyse the pass-through of carbon costs to UK diesel and gasoline prices. The second set covers data from the UK on a monthly basis; it starts in April 2001 and ends in December 2007 (see Figure 2 for a plot of selected series from this data set). The third set reflects data from the EU on a monthly basis for the same period (see Figure 3 for a plot of selected series from this data set). Hence, the results reported in the next section have to be interpreted against this time horizon.

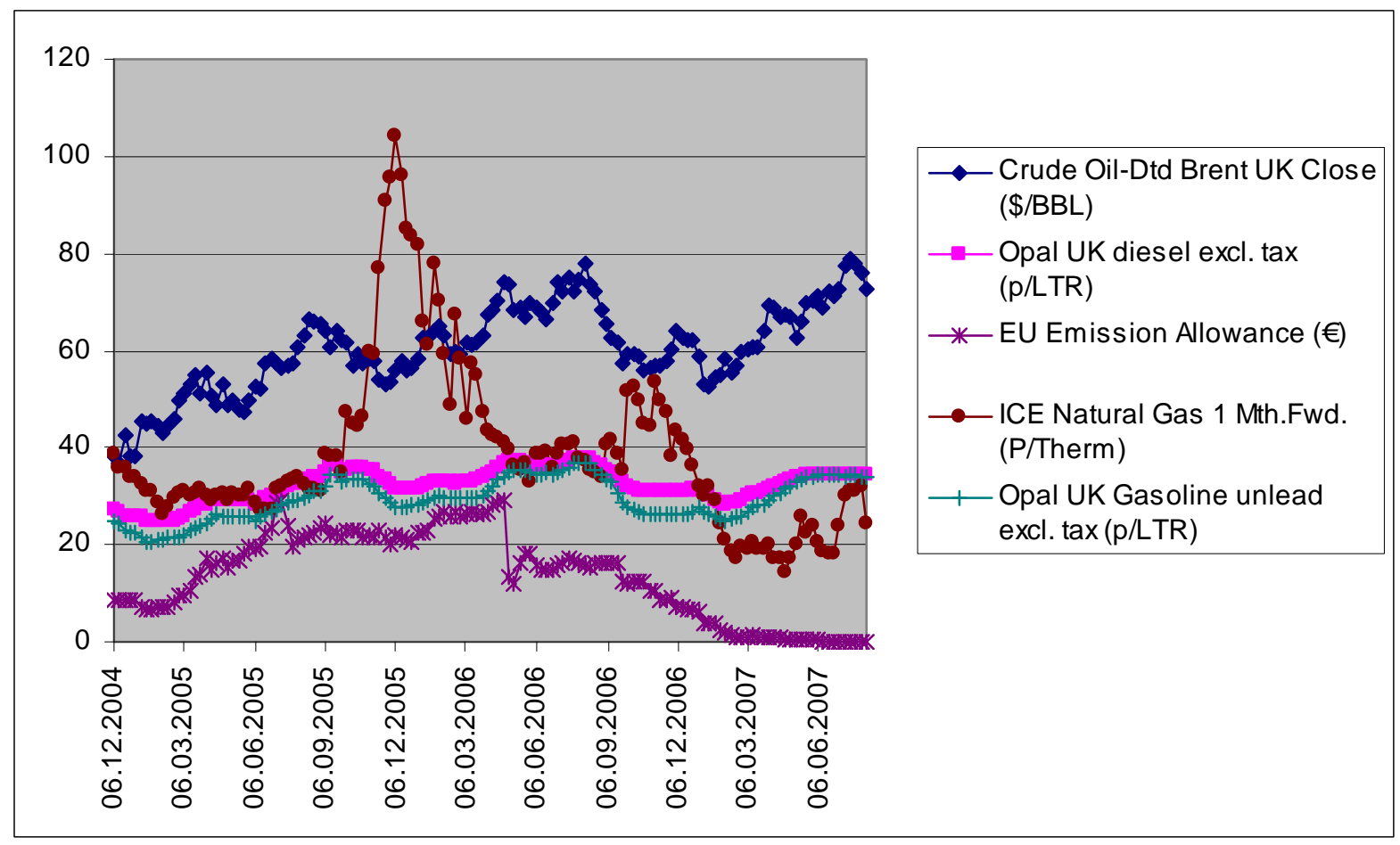

\section{Figure 1 Weekly data UK prices}

The weekly data set provides sufficient observations to measure costs shocks from the EU Emission Allowance market to a given output price, i.e. to assess $\mathrm{CO}_{2}$ cost pass-through for the industry analysed. The weekly output price series covered by this dataset are OPAL UK Diesel and Gasoline (taxes excluded). The series are sourced from Datastream (Thomson Financial) and are output series related to parts of the UK oil industry: The prices represent not only parts of the UK refining industry, but also of the retail industry since no ex-refinery prices were obtained in time for this study. Input price / cost series the weekly data set covers 
the EU Allowance Price (in Euro / ton of $\mathrm{CO}_{2}$; first period; Point Carbon), the UK Interbank Overnight Middle Rate (Datastream; Thomson Financial) representing possible interest rate, i.e. capital cost shocks, the US Dollar to British Pound Sterling exchange rate (Datastream; Thomson Financial; defined in a way that an increase in the exchange rate reflects an appreciation of the British Pound Sterling against the US Dollar), Brent Crude Oil UK Close (Datastream; Thomson Financial; in U.S. Dollar per Barrel), as well as a 1 Month Forward Natural Gas from ICE London (British Pounds per 100.000 BTU; Datastream; Thomson Financial). Due to very time-invariant EUA prices at an extremely low level, it is questionable whether EUA data from 2007 and 2008 can be used in the framework of an empirical analysis (Oberndorfer, forthcoming). Therefore, in the empirical analysis the weekly data sample will end on 31 December 2006, and data from 2007 and 2008 will consequently be dropped.

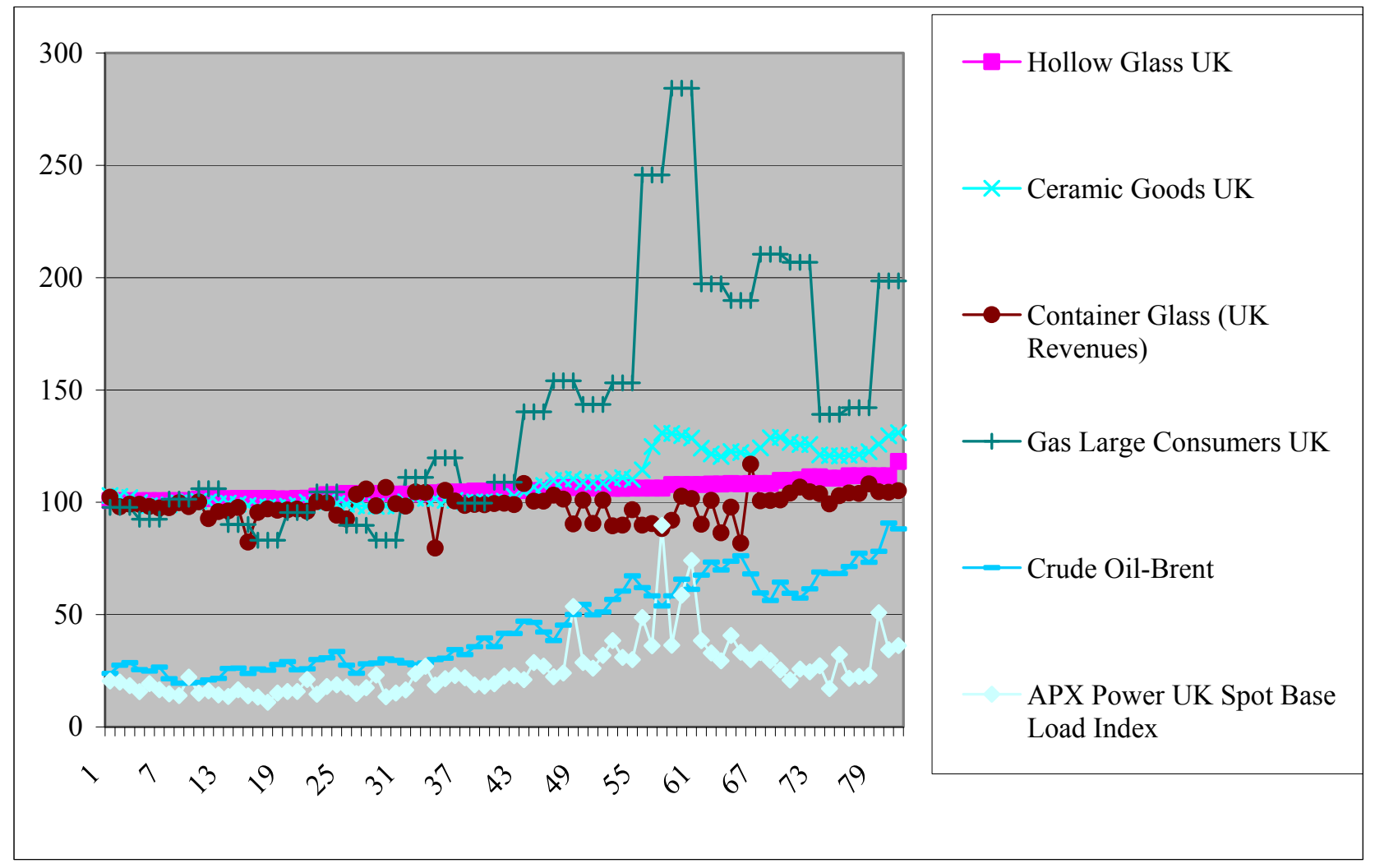

\section{Figure 2 Monthly data UK prices}

Since weakly price data are scant and the emission trading scheme is still in an early stage (i.e. respective time series on carbon prices is relatively short), the passing-through capacity of additional carbon prices cannot be estimated for all sectors owing to insufficient observations for the regression analysis. The UK monthly data set can, however, be used in order to measure cost shocks from markets other than the EU Emission Allowance market 
through to a given output price, i.e. to assess cost pass-through of other costs for the industry analysed. In the absence of the appropriate data, estimating these cost pass-through relationships should approximate sectoral ability to pass on carbon costs to the consumers. The monthly output price series covered by the UK dataset are hollow glass and container glass, all representing output of parts of the UK Glass industry, and a ceramic goods series representing output of a part of the UK ceramics industry. All series are price indices set to the value of 100 for the price level in 2000; the only exception is the container glass series that is measured as the revenue per ton relative to the 2001 average monthly price. All series stem from databases of BERR (now BIS). As far as the glass data is concerned, it has to be specified that hollow glass data represents products defined under hollow glass which include not only container glass as made in the UK but also products which are in effect hollow but are made by different process. These products include tableware products such as drinking glasses and hollow products made from pre-manufactured glass tubing, which, however, are now no longer manufactured in the UK, i.e., these products are imported into the UK. The data labelled as container glass is taken directly from those UK manufacturers of glass containers (bottles and jars, including a very small proportion of flaconnage (small perfume and pharmaceutical products)). Container data represents UK data only and is therefore most representative of the UK container glass industry. Due to confidentiality reasons, analysis for the data set for continuous filament glass fibre and flat glass could not be performed.

The monthly data set for input price/cost series covers:

- UK interbank Overnight Middle Rate (Datastream; Thomson Financial) representing possible interest rate, i.e. capital cost shocks; US Dollar to British Pound Sterling exchange rate (Datastream; Thomson Financial; defined in a way that an increase in the exchange rate reflects an appreciation of the British Pound Sterling against the US Dollar; both not plotted in Figure 2); Brent Crude Oil UK Close (Datastream; Thomson Financial; in US Dollar per Barrel);UK large consumer gas price index from BERR (UK Energy Stats; measured relative to 2001 average quarterly prices);

- APX Power UK Spot Base Load Index (in British Pound Sterling) is included into the dataset in order to account for possible price shocks from the UK electricity market to the sectors analysed. 


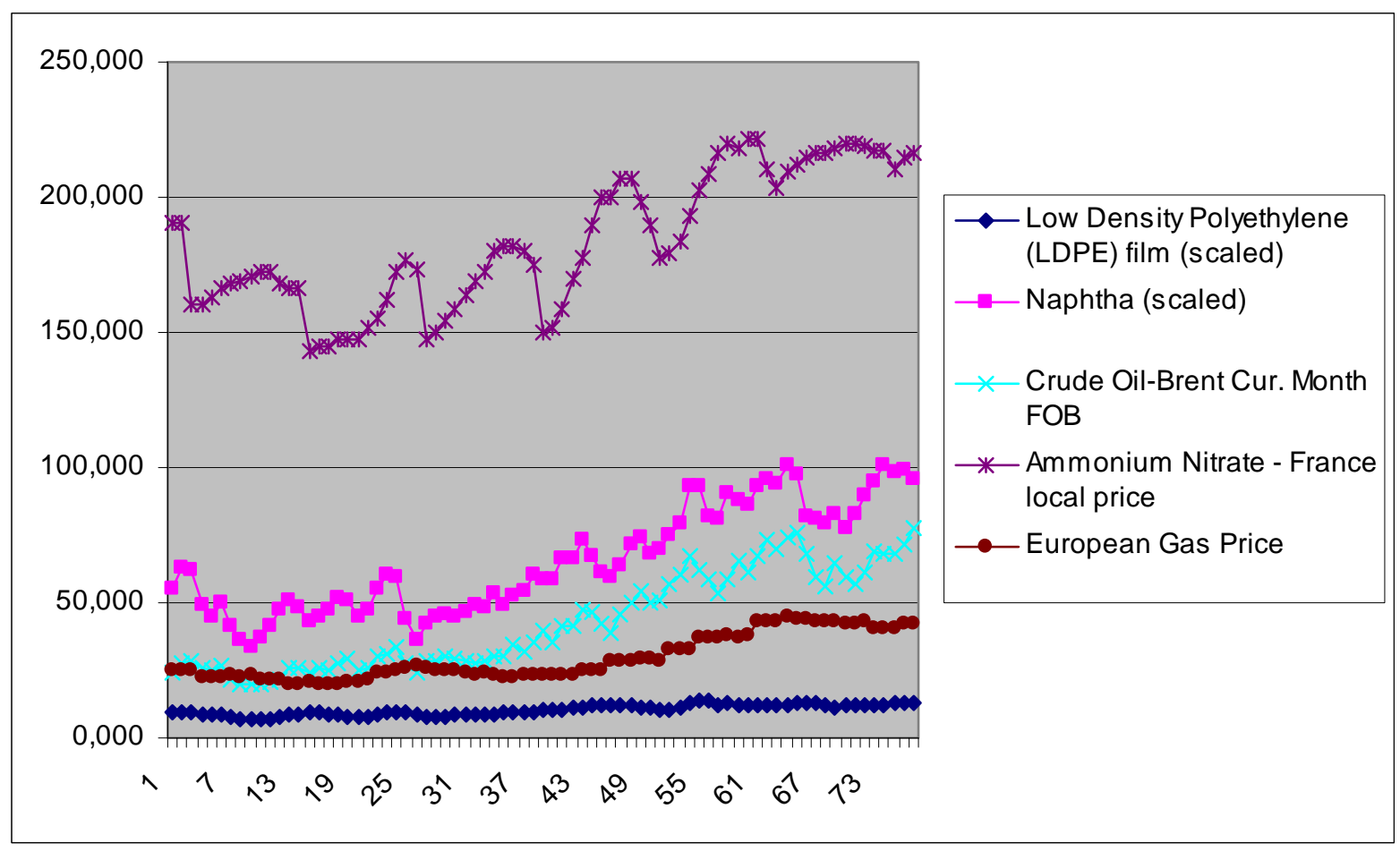

\section{Figure 3 Monthly data EU prices}

Finally, a monthly dataset for the EU is employed. This data set includes Low Density Polyethylene film (LDPE) and Ammonium Nitrate (AN), both for parts of the European chemical industry. Both series are prices given in Euro and stem from databases of the UK Chemical Industries Association (CIA). Input price / cost series the EU monthly data set covers are, the Euro Overnight Index Average (Eonia, Offered Rate; Datastream; Thomson Financial) representing possible interest rate, i.e. capital cost shocks, the Euro to U.S. Dollar exchange rate (Datastream; Thomson Financial; defined in a way that an increase in the exchange rate reflects an appreciation of the U.S. Dollar against the Euro; both not plotted in Figure 3), Brent Crude Oil UK Close (Datastream; Thomson Financial; in Euro per Barrel), which is replaced by a Naphtha price series (CIA; Euro per $2 \mathrm{~kg}$ ) for the analysis of LDPE, as well as a West European gas price index (CIA; Euro). Additionally, the APX Power UK Spot Base Load Index (Datastream; Thomson Financial; Euro) is included into the dataset in order to account for possible price shocks from the electricity market to the sectors analysed.

Of course, the analysis at the EU level relates to a very aggregated level, making it difficult to compare EU sample results with the results from the UK samples. It is therefore necessary in the discussion of the regressions to be clear whether this is UK data or EU wide data that is being used. Alternatively, it is unclear whether the aggregated EU results can be extrapolated 
to the UK level and vice versa. As no UK specific data on LDPE and AN was available for the analysis conducted here, the use of EU-level data seemed to be the most adequate choice. In order to eliminate scaling problems and to make the analysis as transparent as possible as far as coefficient interpretation is concerned, all variables from all data sets are employed in logarithmic form. Regarding descriptive statistics and tests, unit root testing is the most important task in the context of a cost pass-through assessment (see below). In this respect, Dickey-Fuller unit root tests have been employed in both levels and first differences for all variables used in this analysis (see Table 1 for the results regarding the weekly sample, Table 2 for the results regarding the monthly EU sample, and Table 3 for the results regarding the monthly UK sample).

In trying to capture the true relationship in equilibrium between two economic variables, here between input costs and output prices, we might expect some errors to exist. These errors exist both in the data (measurement) and in reality in that firms and the economy are seldom, if ever, perfectly in equilibrium. What we hope in trying to estimate the true relationship is that these errors are small in relation to the true variation in the series, and that they don't move consistently in a particular direction. For statistical purposes, we are much more likely to uncover the true relationship if the series is what is called stationary; it can be expected to return to a particular value of zero. Often, while the original series doesn't possess this property, if we take the differenced series (each value subtracted from its succeeding value) it might have the property which gives the statistical model a greater chance of uncovering the true relationship. A series which can be expected to revert to zero can be said to have a unit root, and the Dicky Fuller test tests for this. In essence, through working with differenced data in this fashion econometricians are trying to strip out any spurious correlation that may exist between the variables.

For the weekly sample, results of these unit root tests suggest that, apart from the interest rate variable, all variables in levels contain a unit root (for the oil price series, the null hypothesis of a unit root can also be rejected, but only at the $10 \%$-level). For all variables in first differenced form, the null hypothesis of a unit root can be rejected at any conventional level, indicating that the interest rate variable is (weakly) stationary, and that all other variables employed are integrated of order one (I(1)). Given these findings, the data for all variables in first differences are used for the econometric analysis. 
Table 1 Dickey-Fuller unit root test weekly sample

\begin{tabular}{|l|l|l|}
\hline & Levels & $\mathbf{1}^{\text {st }}$ Differences \\
\hline OPAL UK Diesel & -1.407 & $-5.362^{* * *}$ \\
\hline OPAL UK Gasoline & & \\
\hline EU Emission Allowance & -1.093 & $-9.329 * * *$ \\
\hline $\begin{array}{l}\text { UK Interbank Overnight Middle } \\
\text { Rate }\end{array}$ & $-4.919 * *$ & $-18.310^{* * *}$ \\
\hline $\begin{array}{l}\text { US Dollar to British Pound Sterling } \\
\text { exchange rate }\end{array}$ & -1.516 & $-9.791^{* * *}$ \\
\hline Brent Crude Oil UK Close & $-2.691 *$ & $-11.667 * * *$ \\
\hline 1 Month Forward Natural Gas & -1.752 & $-11.491^{* * *}$ \\
\hline
\end{tabular}

Note: $* * * * *, *$ denotes rejection of null hypothesis (unit root) at $1-, 5,-10 \%$ level.

For the monthly samples, results of the unit root tests suggest that, apart from the UK interest rate, the container glass, and the electricity price variable, all variables in levels contain a unit root. In contrast, for all variables in first differenced form the null hypothesis of a unit root can be rejected at any conventional level, indicating that the interest rate, container glass, and electricity price variables are (weakly) stationary, and that all other variables employed are integrated of order one (I(1)).

Table 2 Dickey-Fuller unit root test monthly sample EU

\begin{tabular}{|l|l|l|}
\hline & Levels & $\mathbf{1}^{\text {st }}$ Differences \\
\hline $\begin{array}{l}\text { Low Density Polyethylene Film } \\
\text { (LDPE) }\end{array}$ & -1.277 & $-8.579^{* * *}$ \\
\hline AN Index Average & 1.507 & $-7.202^{* * *}$ \\
\hline $\begin{array}{l}\text { Euro Overnight } \\
\text { Offered Rate }\end{array}$ & $-12.781^{* * *}$ \\
\hline Euro to US Dollar exchange rate & -1.546 & $-11.069^{* * *}$ \\
\hline Brent Crude Oil UK Close & -0.876 & $-14.756^{* * *}$ \\
\hline Naphtha & -0.758 & $-12.377^{* * *}$ \\
\hline UK large consumer gas & -1.332 & $-8.789^{* * *}$ \\
\hline $\begin{array}{l}\text { APX Power UK Spot Base Load } \\
\text { Index }\end{array}$ & $-3.762 * *$ & $-14.991^{* * *}$ \\
\hline Not & \\
\hline
\end{tabular}

Note: $* * * * *, *$ denotes rejection of null hypothesis (unit root) at 1-, 5-, and $10 \%$ level. 
Table 3 Dickey-Fuller unit root test monthly sample UK

\begin{tabular}{|c|c|c|}
\hline & Levels & $1^{\text {st }}$ Differences \\
\hline Hollow Glass & 1.887 & $-4.580 * * *$ \\
\hline Container Glass & $-8.131 * * *$ & $-18.178 * * *$ \\
\hline $\begin{array}{l}\text { Low Density Polyethylene Film } \\
\text { (LDPE) }\end{array}$ & -1.277 & $-8.579 * * *$ \\
\hline Ceramic Goods & 0.291 & $-4.886 * * *$ \\
\hline $\begin{array}{l}\text { UK Interbank Overnight Middle } \\
\text { Rate }\end{array}$ & $-4.280 * * *$ & $-14.284 * * *$ \\
\hline $\begin{array}{l}\text { US Dollar to British Pound Sterling } \\
\text { exchange rate }\end{array}$ & -0.987 & $-9.523 * * *$ \\
\hline Brent Crude Oil UK Close & -0.474 & $-9.307 * * *$ \\
\hline UK large consumer gas & -1.293 & $-8.935 * * *$ \\
\hline $\begin{array}{l}\text { APX Power UK Spot Base Load } \\
\text { Index }\end{array}$ & $-3.515 * *$ & $-15.051 * * *$ \\
\hline
\end{tabular}

Note: $* * * * *, *$ denotes rejection of null hypothesis (unit root) at $1-, 5-$, and $10 \%$ level.

As outlined in the introduction, the ability of passing through carbon costs, although widely accepted, is not the only possible response a sector can take to mitigate their potential exposure to EU ETS. Table 4 provides information on energy intensity of selected UK industries. This figure is often used as indicator of exposure to the scheme. Moreover, in order to derive e.g. energy price pass-through rates, not only (estimated) price elasticities, but also information on energy intensity is needed. To illustrate this, an illustrative sector showing an output price elasticity with respect to energy prices of $10 \%$ has a pass-through rate of $100 \%$ (complete pass-through) only if its energy intensity is $10 \%$. For an output price elasticity with respect to energy prices of $10 \%$ and an energy intensity of $50 \%$, the pass-through rate would be $20 \%$. To put it more formally, the pass-through rate of a sector is the output price elasticity with respect to an input price divided by the share of this input factor on overall input costs. A proxy for this share is - in case of the energy factor - the energy intensity. Energy price passthrough rates are given in this paper - but these rates should be interpreted with caution: Foremost, only few of our output prices analysed can be grouped exactly with energy intensities (only hollow glass, ceramic goods, and ceramic bricks). For all other groups, data on energy intensity stem from different sources and are therefore hardly comparable. Moreover, pass through rates could be misleading as the energy intensities reported here do not include all energy costs of the sectors analysed (see below).

In Table 4, based on Eurostat data energy intensity for selected sectors of the UK in 2005 are plotted. Here, energy intensity is calculated as energy purchase divided by the turnover of the respective sector. 
Table 4 overleaf shows that, amongst the sectors empirically analysed in this paper, energy intensity (in relation to turnover ${ }^{1}$ ) is particularly high for producers of fertilisers and nitrogen compounds, and of hollow glass. As energy products purchased as raw materials or for resale without transformation are not covered by the energy purchase figures, however, particularly the energy intensity of the (UK) refining industry is not reflected in this table. According to the industry, energy costs are of typically about $60 \%$ of its total cash operating costs before depreciation or remuneration on investment (Europia, 2008). Moreover, according to a report by Ecofin (2007), ammonium nitrate (based on air/steam reforming) is amongst the most energy intensive products of the chemical industry, with energy costs making up for $66 \%$ of ammonium nitrate prices. For low density polyethylene, this energy cost share, according to Ecofin (2007), amounts to $32 \%$.

\footnotetext{
${ }^{1}$ Readers should note that these data are more typically presented as a ratio to operating costs as opposed to turnover as shown here. This could be a more volatile series as turnover could be more responsive to the economic cycle.
} 


\begin{tabular}{|c|c|c|c|c|}
\hline Sector No. & Sector Definition & $\begin{array}{l}\text { Turnover } \\
\text { (Mio. Euro) }\end{array}$ & $\begin{array}{l}\text { Energy Purchase } \\
\text { (Mio. Euro) }\end{array}$ & $\begin{array}{l}\text { Energy Intensity } \\
(\%)\end{array}$ \\
\hline DG24 & Manufacture of chemicals and chemical products & 73449.9 & 2357.5 & $3.21 \%$ \\
\hline DG241 & Manufacture of basic chemicals & 27520.3 & 1830.2 & $6.65 \%$ \\
\hline DG2413 & Manufacture of other inorganic basic chemicals & 2417.7 & 321.6 & $13.30 \%$ \\
\hline DG2414 & Manufacture of other organic basic chemicals & 12402.5 & 684.3 & $5.52 \%$ \\
\hline DG2415 & Manufacture of fertilisers and nitrogen compounds & 1660.2 & 150.7 & $9.08 \%$ \\
\hline DG2416 & Manufacture of plastics in primary forms & 6317.6 & 321.8 & $5.09 \%$ \\
\hline DG2417 & Manufacture of synthetic rubber in primary forms & 1181.3 & 27.9 & $2.36 \%$ \\
\hline DG242 & Manufacture of pesticides and other agro-chemical products & 1218.1 & 27.8 & $2.28 \%$ \\
\hline DG243 & $\begin{array}{l}\text { Manufacture of paints, varnishes and similar coatings, printing ink } \\
\text { and mastics }\end{array}$ & 5145.2 & 47.1 & $0.92 \%$ \\
\hline DG244 & $\begin{array}{l}\text { Manufacture of pharmaceuticals, medicinal chemicals and botanical } \\
\text { products }\end{array}$ & 23029.7 & 217.7 & $0.95 \%$ \\
\hline DG2441 & Manufacture of basic pharmaceutical products & 1476.9 & 41.8 & $2.83 \%$ \\
\hline DG2442 & Manufacture of pharmaceutical preparations & 21552.7 & 175.9 & $0.82 \%$ \\
\hline DG245 & Manufacture of soap, detergents, cleaning, polishing & 8388.1 & 75.5 & $0.90 \%$ \\
\hline DG2451 & $\begin{array}{l}\text { Manufacture of soap and detergents, cleaning and polishing } \\
\text { preparations }\end{array}$ & 4560.1 & 52.8 & $1.16 \%$ \\
\hline DG2452 & Manufacture of perfumes and toilet preparations & 3828 & 22.7 & $0.59 \%$ \\
\hline DG246 & Manufacture of other chemical products & 7583.7 & 103.5 & $1.36 \%$ \\
\hline DG2461 & Manufacture of explosives & 106.1 & 1.7 & $1.60 \%$ \\
\hline DG2462 & Manufacture of glues and gelatines & 896.4 & 10.3 & $1.15 \%$ \\
\hline DG2463 & Manufacture of essential oils & 795.3 & 5.5 & $0.69 \%$ \\
\hline DG2464 & Manufacture of photographic chemical material & 624.2 & 17.7 & $2.84 \%$ \\
\hline DG2465 & Manufacture of prepared unrecorded media & 332.9 & 2.7 & $0.81 \%$ \\
\hline DG2466 & Manufacture of other chemical products n.e.c. & 4828.7 & 65.6 & $1.36 \%$ \\
\hline DG247 & Manufacture of man-made fibres & 564.8 & 55.8 & $9.88 \%$ \\
\hline DF23 & Manufacture of coke, refined petroleum products and nuclear fuel & 50121.6 & 352.7 & $0.70 \%$ \\
\hline DI26 & Manufacture of other non-metallic mineral products & 18329.4 & 1057.4 & $5.77 \%$ \\
\hline DI261 & Manufacture of glass and glass products & 4863.3 & 298 & $6.13 \%$ \\
\hline DI2613 & Manufacture of hollow glass & 976.6 & 132.3 & $13.55 \%$ \\
\hline DI2614 & Manufacture of glass fibres & 548.3 & 37.3 & $6.80 \%$ \\
\hline
\end{tabular}




\begin{tabular}{|c|c|c|c|c|}
\hline DI2615 & $\begin{array}{l}\text { Manufacture and processing of other glass, including technical } \\
\text { glassware }\end{array}$ & 551.4 & 23.4 & $4.24 \%$ \\
\hline DI262 & $\begin{array}{l}\text { Manufacture of non-refractory ceramic goods other than for } \\
\text { construction purposes; manufacture of refractory ceramic products }\end{array}$ & 1973.2 & 66.2 & $3.35 \%$ \\
\hline DI2621 & Manufacture of ceramic household and ornamental articles & 555.1 & 24.4 & $4.40 \%$ \\
\hline DI2622 & Manufacture of ceramic sanitary fixtures & 607.7 & 15.6 & $2.57 \%$ \\
\hline DI2625 & Manufacture of other ceramic products & 37.1 & 1.1 & $2.96 \%$ \\
\hline DI2626 & Manufacture of refractory ceramic products & 722.8 & 23.5 & $3.25 \%$ \\
\hline DI263 & Manufacture of ceramic tiles and flags & 310.4 & 15.1 & $4.86 \%$ \\
\hline DI264 & Manufacture of bricks, tiles and construction products & 1248.4 & 160.6 & $12.86 \%$ \\
\hline DI265 & Manufacture of cement, lime and plaster & 1381.2 & 224 & $16.22 \%$ \\
\hline DI266 & Manufacture of articles of concrete, plaster, cement & 6319.8 & 234.6 & $3.71 \%$ \\
\hline DI2661 & Manufacture of concrete products for construction purposes & 3828.3 & 95.6 & $2.50 \%$ \\
\hline DI2662 & Manufacture of plaster products for construction purposes & 1120.5 & 67.2 & $6.00 \%$ \\
\hline DI2663 & Manufacture of ready-mixed concrete & 898.4 & 43.9 & $4.89 \%$ \\
\hline DI2666 & Manufacture of other articles of concrete, plaster and cement & 193.3 & 4 & $2.07 \%$ \\
\hline DI267 & Cutting, shaping and finishing of ornamental and building stone & 586.3 & 19 & $3.24 \%$ \\
\hline DI268 & Manufacture of other non-metallic mineral products & 1646.8 & 40 & $2.43 \%$ \\
\hline DI2681 & Production of abrasive products & 359.7 & 4.8 & $1.33 \%$ \\
\hline$\overline{\mathrm{DI} 2682}$ & Manufacture of other non-metallic mineral products n.e.c. & 1287.1 & 35.2 & $2.73 \%$ \\
\hline
\end{tabular}

Note: Data for 2005. Data source: Eurostat. Turnover: Turnover comprises the totals invoiced by the observation unit during the reference period, and this corresponds to market sales of goods or services supplied to third parties. Turnover includes all duties and taxes on the goods or services invoiced by the unit with the exception of the VAT invoiced by the unit vis-à-vis its customer and other similar deductible taxes directly linked to turnover. It also includes all other charges (transport, packaging, etc.) passed on to the customer, even if these charges are listed separately in the invoice. Reduction in prices, rebates and discounts as well as the value of returned packing deducted. Income classified as other operating income, financial income and extra-ordinary income in company accounts is excluded from turnover. Operating subsidies received from public authorities or the institutions of the European Union are also excluded. Energy Purchase: Purchases of all energy products during the reference period if purchased to be used as fuel. Energy products purchased as raw materials or for resale without transformation excluded. Energy Intensity: Energy Purchase/Turnover. 


\section{Methodology}

The assessment of cost pass-through is about linking input to output prices. In the following, the most common approaches in modelling cost pass-through are presented. The basic framework in order to assess a cost pass-through to any output price $y_{t}(t=1, \ldots, T)$ is an autoregressive distributed lag model (ARDL). Here, the output price $y_{t}$ depends on a vector $Y$ of its own lags $y_{t-a}$ and, for the simplest case with only one relevant input price, on a vector $X$ of both contemporaneous and lagged prices $x_{t-b}$. The respective ARDL can be specified as

$y_{t}=\sum_{a=1}^{u} \gamma_{a} y_{t-a}+\sum_{b=0}^{v} \alpha_{b} x_{t-b}+\varepsilon_{t}$

with parameters $\gamma_{a}, \alpha_{b}$, and disturbance term $\varepsilon_{t}$ (that is independent and identically distributed over time $(t=1, \ldots, T))$ to be estimated. The ARDL framework can easily capture more than one input price series. In such - more realistic - case, formally, the input price vector $\mathrm{X}$ is replaced by an input price matrix containing different input price vectors.

If the series considered in ARDL model are stationary (i.e. I(0)), this version of the ARDL can be consistently estimated using OLS. If they are non-stationary (I(1), i.e. integrated of $1^{\text {st }}$ order), however, applying OLS can lead to so-called spurious regression, i.e. the null hypothesis of no impact of the respective explanatory variables on $y_{t}$ e.g. at the $5 \%$-level is rejected in more than the expected $5 \%$ of a series in repeated experiments (Granger and Newbold, 1974). In fact, many price series appear to be I(1), and are therefore susceptible to so-called spurious regression (Meyer and von Cramon-Taubadel, 2004). According to the results of unit root tests (see above), this also holds for most of the series entering in this analysis (see for more intuitive explanations on the importance of the unit root tests in the Chapter 2). The easiest way of dealing with this issue is transforming the data series by taking differences of the respective series (e.g., first differences if the series are, as often, integrated of order one), as regressions with $\mathrm{I}(0)$ - in contrast to $\mathrm{I}(1)$-variables - are consistent in any case (i.e. if there are no other concern regarding consistency such as reverse causality). The ARDL is then applied to differenced $(\Delta) y$-and $x$-series. 
The ARDL (in first differences) can incorporate asymmetries with respect to the impact of contemporary and lagged input prices, i.e. according to whether the sign of the respective input price change $\Delta x_{t}$ is positive $\left(\Delta x_{t}^{+}\right)$or negative $\left(\Delta x_{t}^{+}\right)$, by generalising (1) (for differenced series) to

$$
\Delta y_{t}=\sum_{a=1}^{u} \gamma_{a} \Delta y_{t-a}+\sum_{b=0}^{v} \alpha_{b}^{+} \Delta x_{t-b}^{+}+\sum_{c=0}^{v} \alpha_{c}^{-} \Delta x_{t-c}^{-}+\varepsilon_{t}
$$

Existing empirical studies have provided evidence for the existence of asymmetric price transmission particularly for gasoline (Borenstein et al., 1997, Brown and Yücel, 2000), for agricultural goods (for a survey, see Meyer and von Cramon-Taubadel, 2004), but also for many other products (e.g. Peltzman, 2000, who analyses a large sample of 77 consumer and 165 producer goods). Moreover, and particularly relevant for this study, Zachmann and von Hirschhausen (2008) provide evidence for asymmetric cost pass through with respect to carbon costs created by the EU ETS: According to their results, rising EUA prices affect German wholesale electricity prices more strongly than falling EUA prices.

According to Frey and Manera (2007), a necessary condition for the presence of asymmetric price effects is price rigidity, which gives rise to sluggish adjustment of output prices to shocks in cost conditions. However, according to Peltzman (2000), "economic theory suggests no pervasive tendency for prices to respond faster to one kind of cost change than to another" (p. 467). Yet, there are a number of theoretical arguments that can be put forth on the issue of asymmetric adjustment which is an example of Post Keynesian analysis. Extensive surveys of the theoretical literature in this direction are provided by Frey and Manera (2007), and Meyer and von Cramon-Taubadel (2004). To sum up, market power, menu costs, as well as accountancy rules and inventory valuation may be responsible for asymmetric pass-through of cost shocks. In case that market power was the effective explanation for asymmetric carbon price transmission for any sector, evidence for this phenomenon could imply that the respective sector would be less vulnerable to carbon leakage.

An important issue with respect to all specifications to be estimated is the question of whether structural breaks are present in the data. Econometric adjustment for possible breaks in the data could yield additional insights and change the parameter estimates. Unfortunately, the small number of observations for all specifications exacerbates the testing for structural 
breaks (Bai and Perron, 1998). Therefore, structural breaks are not tested. An extension of the analysis with respect to such possible breaks remains an area for future research.

In the next section, we report our results giving point estimates that should indicate the percentage change of the output price change as a reaction to a $1 \%$ change of the respective input price change. These point estimates are summed up over the respective lagged parameters of any input price change in order to receive the percentage change of output price changes to a $1 \%$ change in the input price changes over time. 


\section{Results}

Against the background of nearly all variables used being integrated of order one (I(1)) according to Dickey-Fuller unit root tests, we apply the ARDL in first differences for all variables. The purpose of this procedure is to avoid so-called spurious regression results (see above). In this section, we firstly present results for UK weekly data, i.e. for UK diesel and gasoline. Secondly, we report our findings for EU monthly data, i.e. for low density polyethylene film and ammonium nitrate. Thirdly, we present the results for UK monthly data, i.e. for hollow glass, container glass, and for ceramic goods. For all products, the symmetric specification that is preferable according to the Akaike and the Bayesian Schwarz Information Criterion is reported in this section (for all products, this is the specification including one lag for each explanatory variable). Symmetric specifications including three and five lags - as a robustness check - as well as asymmetric specifications with respect to one important input price including one and three lags are reported in the appendix. Ideally, longer histories would have been used in arriving at the monthly econometric estimates, but longer data histories that would have permitted this only became available after the modelling part of this study had been completed.

Generally, point estimates are associated with some uncertainty, as they only give the mean of the estimated distribution (e.g., Greene, 2003). Therefore, the values are not exact and should be interpreted with caution. In this paper, all tables contain both means and standard deviations as the precision associated with the cost pass-through estimates has to be evaluated based on the standard deviations. Generally, we consider estimated relationships as being significant only if statistical tests suggest that the error probability of rejecting the null hypothesis of no impact is very small. 


\subsection{Results weekly data UK}

\section{OPAL UK Diesel}

According to the results of both Akaike's and Schwartz' Bayesian Information Criteria (AIC/BIC), an ARDL containing levels and first lags of all explanatory variables (plus the first lag of the endogenous variable) should be used in case of the analysis for OPAL UK Diesel (sector refineries). Results of this regression approach are presented in Table 5. The results, particularly with respect to the EUA coefficients, are very robust with respect to the inclusion of insignificant explanatory variables as well as of further lags of those variables (see Table 13 and Table 14).

Table 5 Diesel ARDL regression results weekly data (1 lag)

\begin{tabular}{|c|c|}
\hline \multicolumn{2}{|l|}{ Dep. Var.: $\triangle$ OPAL UK Diesel } \\
\hline const & $\begin{array}{l}0.00 \\
(0.00)\end{array}$ \\
\hline L1 $\Delta$ OPAL UK Diesel & $0.57 * * *$ \\
\hline & $(0.10)$ \\
\hline$\Delta$ EU Emission Allowance & 0.00 \\
\hline & $(0.01)$ \\
\hline L1 $\Delta$ EU Emission Allowance & $0.03 * *$ \\
\hline & $(0.01)$ \\
\hline$\Delta$ UK Interbank Overnight Middle Rate & -0.03 \\
\hline & $(0.03)$ \\
\hline L1 $\Delta$ UK Interbank Overnight Middle Rate & 0.02 \\
\hline & $(0.04)$ \\
\hline$\Delta$ US Dollar to British Pound Sterling exchange rate & 0.04 \\
\hline & $(0.10)$ \\
\hline L1 $\Delta$ US Dollar to British Pound Sterling exchange rate & $0.22 *$ \\
\hline & $(0.13)$ \\
\hline$\Delta$ Brent Crude Oil UK Close & -0.03 \\
\hline & $(0.03)$ \\
\hline L1 $\Delta$ Brent Crude Oil UK Close & 0.06 \\
\hline & $(0.04)$ \\
\hline$\Delta 1$ Month Forward Natural Gas & 0.00 \\
\hline & $(0.01)$ \\
\hline L1 $\Delta 1$ Month Forward Natural Gas & 0.00 \\
\hline & $(0.01)$ \\
\hline Obs. & 106 \\
\hline R-squared & 0.46 \\
\hline F-Test & $8.88 * * *$ \\
\hline AIC & -622.34 \\
\hline $\mathrm{BIC}$ & -590.38 \\
\hline
\end{tabular}

Note: White heteroskedasticity-robust standard errors in brackets. ${ }^{*}, * *$ and $*^{* *}$ show significance at the $10 \%-$, $5 \%$, and 1\%-level, respectively. None of the specification tests indicates misspecification.

These results suggest that at least part of the carbon cost has been passed on to diesel consumers. Depending on the specification and abstracting from the dynamics in the diesel 
price, point estimates suggest that a change in the increase of the EUA price by $1 \%$ has, over time, led to an increase of costs for OPAL UK diesel of about $0.03 \%$ to $0.06 \%$. Point estimates are, as mentioned above, not exact, as they only give the mean of the estimated distribution (in this case, for the relationship between the EU Emission allowance price change and the diesel price change; e.g., Greene, 2003). Further, in the regressions including more lags than suggested by the AIC and BIC the pass-through of oil prices as the most important cost factor for the refineries industry can be observed. Point estimates suggest here that a $1 \%$ increase in the oil price led to an increase of the costs for OPAL UK diesel of up to $0.27 \%$ for a period of five weeks (cp. also Figure 4). Against the background of energy costs typically representing about $60 \%$ of total cash operating costs of the UK oil industry before depreciation or remuneration on investment (Europia, 2008), this would mean that roughly $50 \%$ of energy price increases are passed through to retail consumers of diesel within five weeks. As the refineries data used is retail sales rather than ex-refinery data (see above), this figure does not necessarily reflect the ability of refineries to pass on costs to retailers. However, these findings would only be invalidated if systematic variations in the ex-refinery to retail margin were to occur.

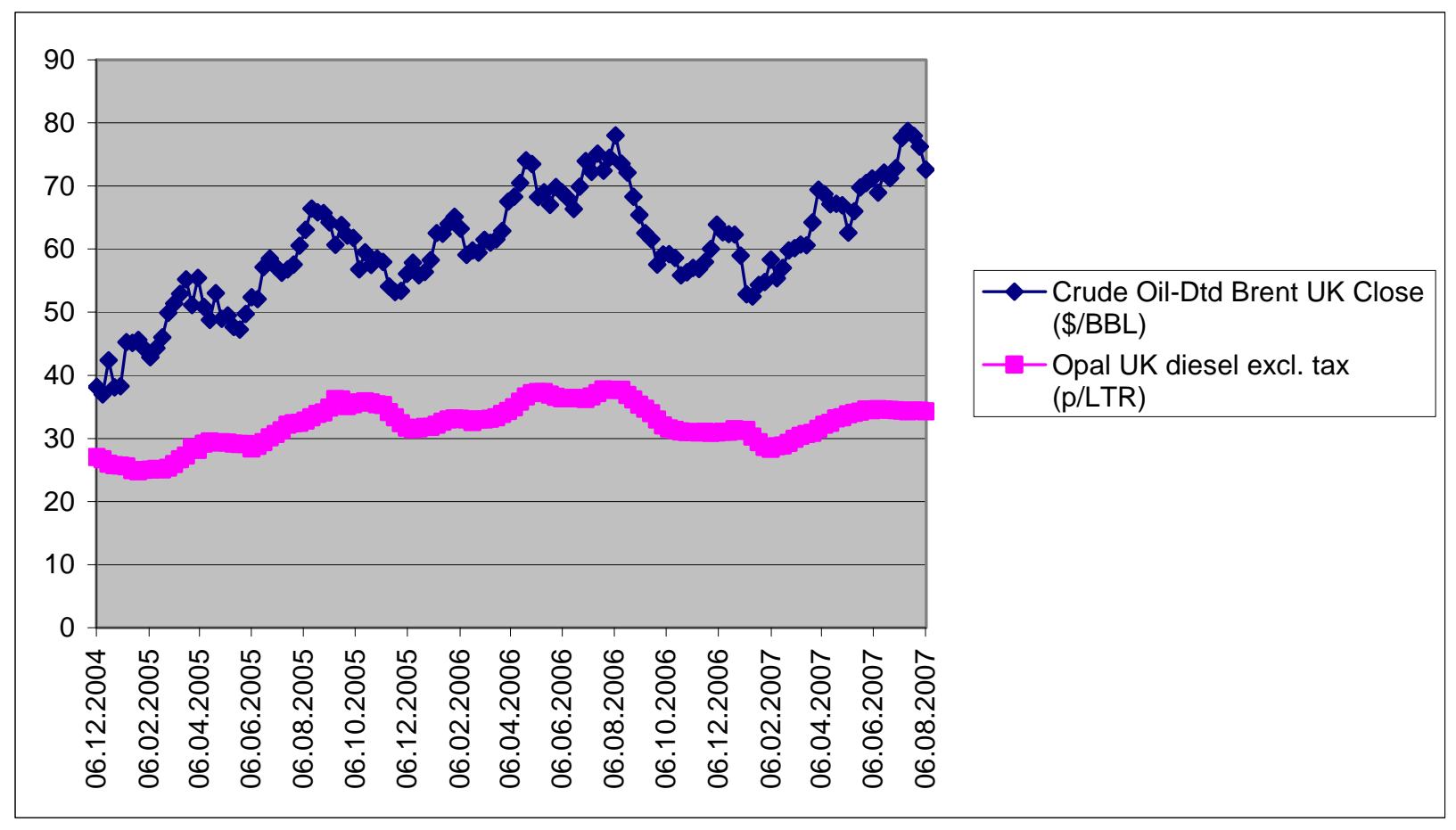

Figure 4 Weekly data UK prices - Diesel 
While our estimations show that EUA prices are - at least partly - passed on to the consumers via diesel prices, we do not find any evidence for an asymmetric price transmission from the EU carbon to the UK diesel market. Results of an asymmetric ARDL specification with respect to the EUA price input are plotted in Table 15 and Table 16. Both specifications do not suggest that responses of the UK diesel price with respect to the sign of carbon price changes differ significantly from each other.

\section{OPAL UK Gasoline}

According to the results of both Akaike's and Schwartz' Bayesian Information Criteria (AIC/BIC), an ARDL containing levels and first lags of all explanatory variables (plus the first lag of the endogenous variable) should be used in case of the analysis for OPAL UK Gasoline (sector refineries). Results of this regression approach are presented in Table 6. As in the case of UK diesel, the results with respect to the EUA coefficients are very robust with respect to the inclusion of insignificant explanatory variables as well as of further lags of those variables (see Table 17 and Table 18). 
Table 6 Gasoline ARDL regression results weekly data (1 lag)

\begin{tabular}{|c|c|}
\hline \multicolumn{2}{|l|}{ Dep. Var.: $\triangle$ OPAL UK Gasoline } \\
\hline const & $\begin{array}{l}0.00 \\
(0.00)\end{array}$ \\
\hline L1 $\Delta$ OPAL UK Gasoline & $\begin{array}{l}0.66^{* * *} * \\
(0.09)\end{array}$ \\
\hline$\Delta$ EU Emission Allowance & $\begin{array}{l}0.01 \\
(0.01)\end{array}$ \\
\hline L1 $\Delta$ EU Emission Allowance & $\begin{array}{l}0.03 * * \\
(0.01)\end{array}$ \\
\hline$\Delta$ UK Interbank Overnight Middle Rate & $\begin{array}{l}0.01 \\
(0.04)\end{array}$ \\
\hline L1 $\Delta$ UK Interbank Overnight Middle Rate & $\begin{array}{l}-0.01 \\
(0.04)\end{array}$ \\
\hline$\Delta$ US Dollar to British Pound Sterling exchange rate & $\begin{array}{l}0.21 \\
(0.14)\end{array}$ \\
\hline L1 $\Delta$ US Dollar to British Pound Sterling exchange rate & $\begin{array}{l}0.27 \\
(0.19)\end{array}$ \\
\hline$\Delta$ Brent Crude Oil UK Close & $\begin{array}{l}-0.09 * * \\
(0.04)\end{array}$ \\
\hline L1 $\Delta$ Brent Crude Oil UK Close & $\begin{array}{l}0.08 * * \\
(0.04)\end{array}$ \\
\hline$\Delta 1$ Month Forward Natural Gas & $\begin{array}{l}0.01 \\
(0.02)\end{array}$ \\
\hline L1 $\Delta 1$ Month Forward Natural Gas & $\begin{array}{l}0.01 \\
(0.02)\end{array}$ \\
\hline Obs. & 106 \\
\hline R-squared & 0.52 \\
\hline F-Test & $9.79 * * *$ \\
\hline $\mathrm{AIC}$ & -550.84 \\
\hline BIC & -518.88 \\
\hline
\end{tabular}

Note: White heteroskedasticity-robust standard errors in brackets. *,** and *** show significance at the $10 \%-$, $5 \%$-, and 1\%-level, respectively. None of the specification tests indicates misspecification.

As in the case of diesel, these results suggest that at least parts of the carbon costs have been passed on to the gasoline consumers. Point estimates suggest that a change in the increase of the EUA price by $1 \%$ has, over time, led to change in the increase of the costs for OPAL UK gasoline of about $0.01 \%$ to $0.03 \%$. Similarly to UK diesel, regression analysis for UK gasoline suggests that oil prices are the most important cost factor for the refineries industry (cp. also Figure 5). Point estimates suggest here that a change in the increase of the oil price by $1 \%$ has, for the period of five weeks, led to a change in the increase of the costs for OPAL UK gasoline of up to $0.45 \%$. Against the background of energy costs typically representing about $60 \%$ of total cash operating costs of the UK oil industry before depreciation or remuneration on investment (Europia, 2008), this would mean that roughly $75 \%$ of energy price increases are passed through to gasoline consumers within five weeks. As the refineries data used is retail sales rather than ex refinery data (see above), this figure does not necessarily refer to the ability of refineries to pass on costs to retailers. However, the analysis 
suggests that the pass-through particularly of the EU Allowance price actually refers to the refineries sector, as this is the sector in the production chain that is directly affected by the EU ETS. It is rather implausible that retailers adjust their margin in reaction to EU Allowance price changes (which is the alternative explication to the significant EU Allowance price coefficient if the refineries sector were not responsible for the pass through of EU Allowance costs).

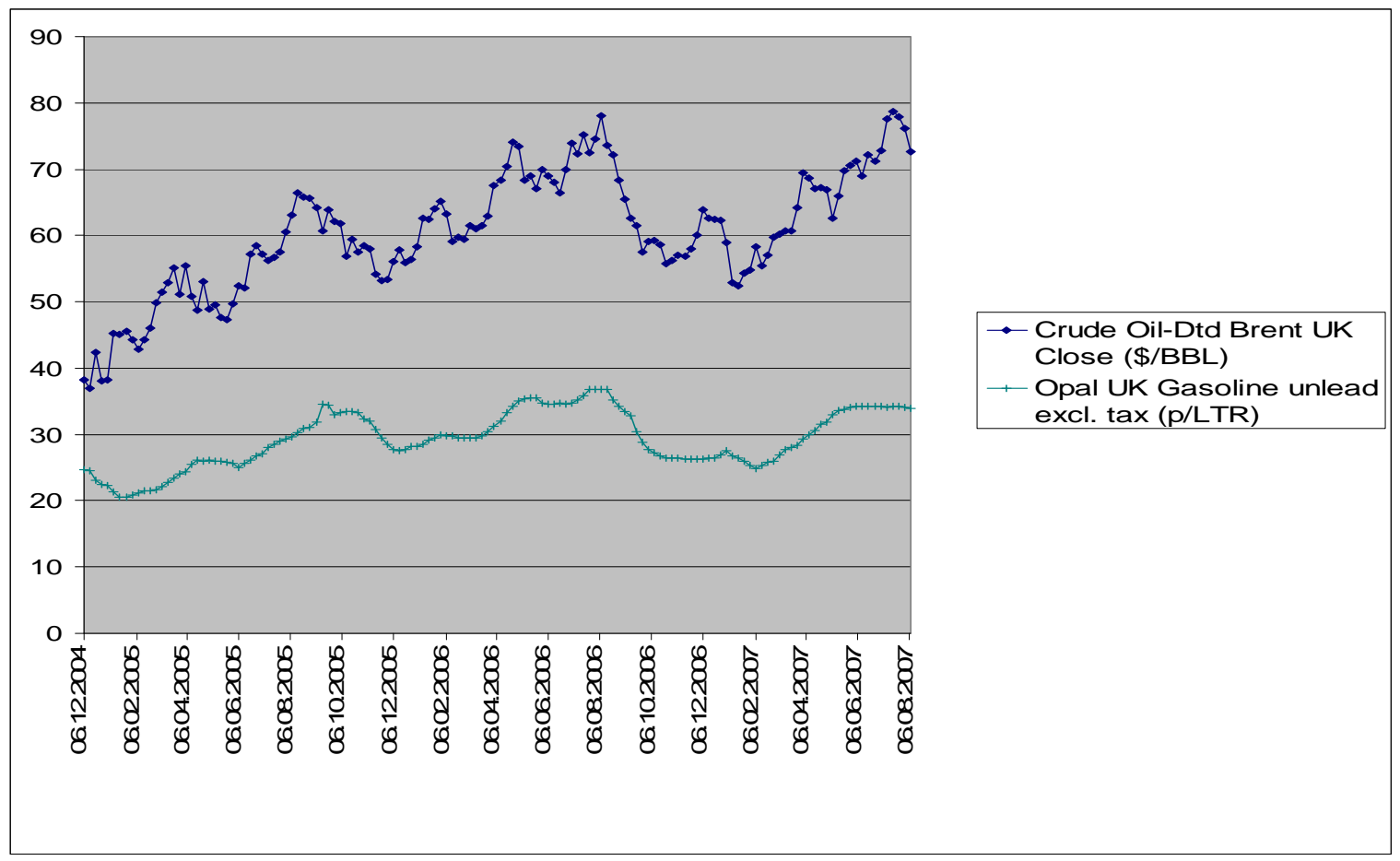

\section{Figure 5 Weekly data UK prices - Gasoline}

While our estimations show that EUA prices are - at least partly - passed on to the consumers via diesel prices, we do not find evidence for an asymmetric price transmission from the EU carbon to the UK gasoline market. Results of an asymmetric ARDL specification with respect to the EUA price input are plotted in Table 19 and Table 20. As in the UK diesel case, neither specification suggests that responses of the UK gasoline price with respect to carbon price signals significantly differ from each other. In principle, one might expect that prices would be fully passed on over a longer time horizon (i.e. if the lag length would be longer). 


\subsection{Results monthly data EU}

In the analysis based on monthly data, we analyse pass-through of non-carbon cost shocks. This is due to the fact that monthly data from the EU ETS would give too few observations in order to conduct a serious ARDL regression analysis. We therefore assess pass-through of cost shocks from the oil, gas, electricity, interest rate, and exchange rate market. Those results should indicate whether sectors are capable to pass through EUA price shocks. In case of the analysis of LDPE (low density polyethylene film) prices, oil prices are replaced by prices of naphtha, a fraction of crude oil that is relevant for the LDPE production.

For the analysis of UK-specific prices, cost shocks that are EU-specific should be particularly relevant, i.e. costs that foreign competitors in these sectors would not face. The ability to pass through costs which are common to domestic and foreign producers (i.e. input factors being traded at the world markets) is not analysed in this paper. In this respect the (Euro to U.S. Dollar) exchange rate shocks are relevant, as are interest rate, electricity and gas price shocks. These should represent EU-specific cost shocks as interest rate and exchange rate developments with respect to EU interest rates and the Euro to U.S. Dollar exchange rate are, by definition, EU-specific. Electricity and gas price shocks should also be rather EU-specific as gas and electricity prices in the EU may often decouple from the price level in countries outside Europe (Zachmann, 2008). However, particularly in cases when the null hypothesis of no pass-through cannot be rejected, estimation results have to be handled with care: In principle, exchange rate shocks will not necessary have an impact on all producers but rather on those with pronounced exporting activities. Hence, the absence of interest rate passthrough may be a sign of lack of economic relevance of the interest rate variable rather than non-ability of passing-through the price shock in the respective sector. UK electricity prices (Zachmann, 2008) may decouple from the price level in continental Europe. Therefore, these data may be a bad proxy for electricity prices in Europe as a whole where there is no uniform price for this good. In this sense, it seems possible that our estimations for the European output prices analysed (low density polyethylene film and ammonium nitrate) do not indicate statistically significant pass through of electricity prices, although in reality these prices are passed through. The reason for the lack of statistical significance may be the use of UK electricity prices, which are generally less regulated than EU electricity prices. Generally, 
ability of pass-through should be signed by a positive and statistically significant coefficient for the respective cost shock.

Although one might question whether this use of monthly data is a relevant methodology, the authors of this study believe it to be robust. If firms did not price the opportunity cost of allowances in the same way in which they price other inputs then the methodology might not be relevant, but this behaviour on the part of firms would fly in the face of economic theory.

\section{Low density polyethylene film}

For low density polyethylene film (LDPE; Table 7) our results indicate that pass-through particularly of - at least parts of - naphtha cost shocks is possible (cp. also Figure 6). Naphtha is a basic feedstock in production of LDPE. According to our point estimates here, the respective price elasticity takes a value of 0.32 . Considering more lags than suggested by the information criteria applied (see Table 21 and Table 22), this value even rises. There is no strong evidence of pass-through of any other prices incorporated in the empirical analysis. Against the background of, according to Ecfin (2007), an energy cost share of $32 \%$, point estimates in the model considering one lag suggest that energy price increases are fully passed through to LDPE consumers. This may vary if more lags were estimated. It is possible that firms are tempted to pass through the costs to preserve profit margins but then realise that the impact on market share is too great and subsequently withdraw the cost increase. Firms might even engage in strategic pricing games in which the pass-through would indeed depend on the expectations about the competitor's behaviour. From a theoretical perspective, it is even possible that competitors increase their prices thereby increasing profit margin at the expense of losing market share. 


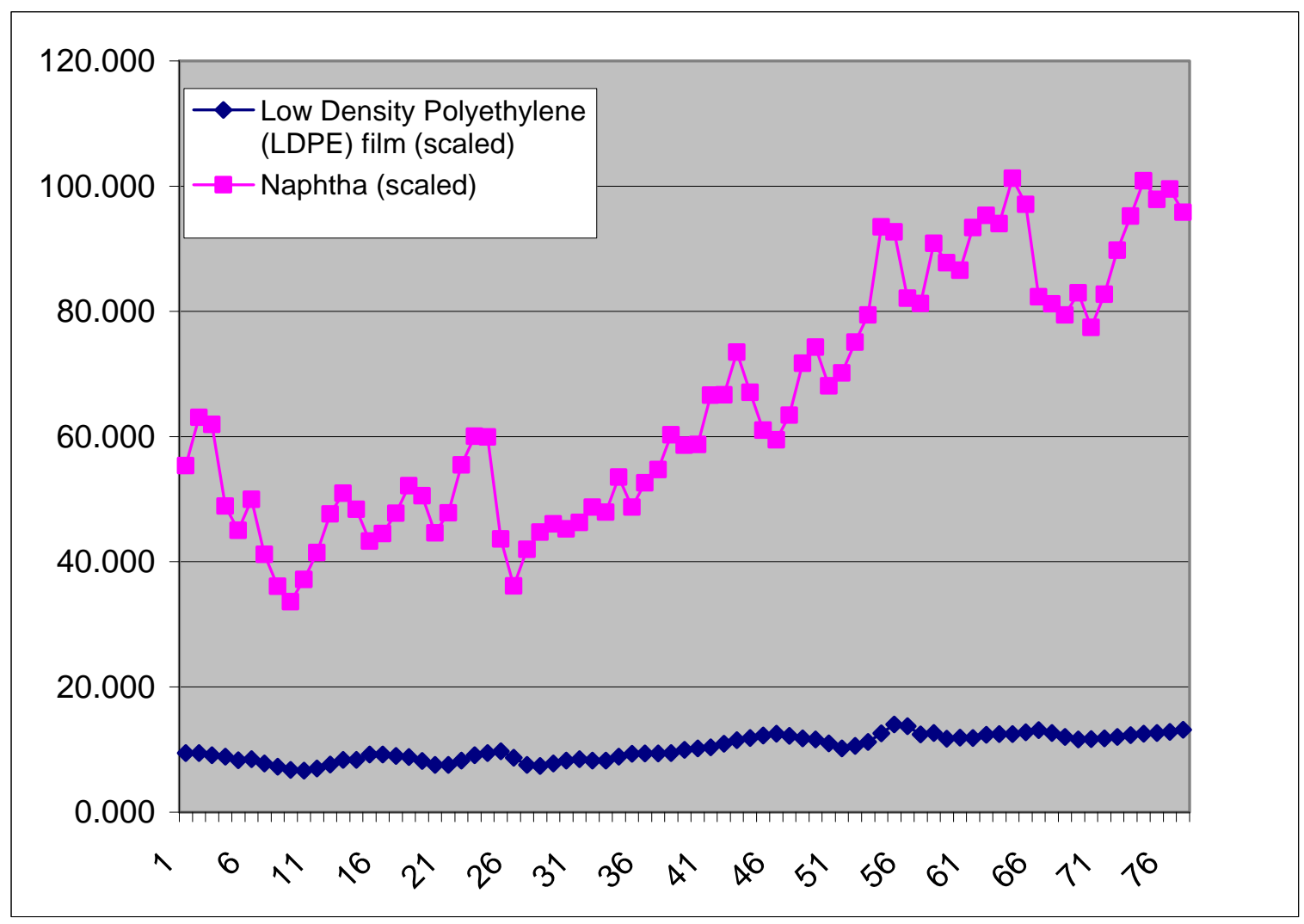

Figure 6 Monthly data EU prices - LDPE 
Table 7 LDPE ARDL regression results monthly data (1 lag)

\begin{tabular}{|l|l|}
\hline Dep. Var.: $\Delta$ LDPE & -0.00 \\
const & $(0.00)$ \\
L1 $\Delta$ LDPE & $0.41^{* * *}$ \\
& $(0.10)$ \\
L1 $\Delta$ APX Power UK Spot Base Load Index & $-0.03^{*}$ \\
& $(0.02)$ \\
$\Delta$ Euro Overnight Index Average Offered Rate & 0.01 \\
& $(0.02)$ \\
L1 $\Delta$ Euro Overnight Index Average Offered Rate & -0.04 \\
& $(0.08)$ \\
L1 $\Delta$ Euro to US Dollar exchange rate & -0.04 \\
& $(0.08)$ \\
$\Delta$ Naphtha & 0.37 \\
L1 $\Delta$ Naphtha Dollar exchange rate & $(0.25)$ \\
$\Delta$ West European gas & -0.06 \\
& $(0.24)$ \\
L1 $\Delta$ West European gas & $0.13 * *$ \\
& $(0.07)$ \\
\hline Obs. & $0.20^{* * *}$ \\
R-squared & $(0.06)$ \\
AIC & 0.09 \\
BIC & $(0.14)$ \\
Note: White heteroskedastity-robust Standard & -0.04 \\
\end{tabular}

Note: White heteroskedasticity-robust standard errors in brackets. ${ }^{*},{ }^{*}$ and ${ }^{* * *}$ show significance at the $10 \%$, $5 \%$, and 1\%-level, respectively. None of the specification tests indicates misspecification.

There is no empirical evidence for an asymmetric pricing of LDPE with respect to naphtha. Considering a one (Table 23) and a three lag (Table 24) specification, respectively, there is no indication for asymmetric reactions of the European LDPE price to naphtha prices. This might suggest that firms in the sector do not enjoy significant market power.

\section{Ammonium nitrate}

Analysing French ammonium nitrate (AN) prices that are considered to be the best available indicator for European AN prices as a whole, our estimates suggest that gas is a particularly important factor (Table 8). Due to reasons of confidentiality, UK data could not be used. In this regard, the ARDL framework suggests that partial pass-through of gas prices to the price of the final AN product in Europe occurs (cp. also Figure 7). Considering up to three (Table 25 ) and five (Table 26) lags, respectively, we receive estimated price elasticities of AN to gas of up to 0.37 . Since, according to a report by Ecofin (2007), energy costs make up for $66 \%$ of ammonium nitrate prices, this suggests that energy pass-through rates for AN are around 50 to $60 \%$. 
Table 8 Ammonium nitrate ARDL regression results monthly data (1 lag)

\begin{tabular}{|c|c|}
\hline \multicolumn{2}{|l|}{ Dep. Var.: $\triangle$ Ammonium Nitrate } \\
\hline const & $\begin{array}{l}0.00 \\
(0.01)\end{array}$ \\
\hline L1 $\Delta$ Ammonium Nitrate & $\begin{array}{l}0.22^{*} \\
(0.12)\end{array}$ \\
\hline$\triangle$ APX Power UK Spot Base Load Index & $\begin{array}{l}0.03 * * \\
(0.02)\end{array}$ \\
\hline L1 $\triangle$ APX Power UK Spot Base Load Index & $\begin{array}{l}0.04 * * \\
(0.02)\end{array}$ \\
\hline$\Delta$ Euro Overnight Index Average Offered Rate & $\begin{array}{l}0.01 \\
(0.07)\end{array}$ \\
\hline L1 $\Delta$ Euro Overnight Index Average Offered Rate & $\begin{array}{l}-0.07 \\
(0.06)\end{array}$ \\
\hline$\Delta$ Euro to US Dollar exchange rate & $\begin{array}{l}0.04 \\
(0.31)\end{array}$ \\
\hline L1 $\Delta$ Euro to US Dollar exchange rate & $\begin{array}{l}0.12 \\
(0.27)\end{array}$ \\
\hline$\Delta$ Brent Crude Oil UK Close & $\begin{array}{l}-0.04 \\
(0.07)\end{array}$ \\
\hline L1 $\Delta$ Brent Crude Oil UK Close & $\begin{array}{l}0.01 \\
(0.08)\end{array}$ \\
\hline$\Delta$ West European gas & $\begin{array}{l}0.01 \\
(0.08)\end{array}$ \\
\hline L1 $\Delta$ West European gas & $\begin{array}{l}0.07 \\
(0.10)\end{array}$ \\
\hline Obs. & 78 \\
\hline R-squared & 0.13 \\
\hline F-Test & $1.83 *$ \\
\hline AIC & -245.57 \\
\hline $\mathrm{BIC}$ & -217.29 \\
\hline
\end{tabular}

Note: White heteroskedasticity-robust standard errors in brackets. ${ }^{*}, * *$ and $* * *$ show significance at the $10 \%$, $5 \%$-, and 1\%-level, respectively. None of the specification tests indicates misspecification.

Moreover, the consideration of asymmetric gas price effects on the French AN price suggests that the relationship between both price series is not symmetric. The point estimates presented in Table 27 and Table 28 suggest that a change in the gas price increase by $1 \%$ leads to a change in the AN price increase of, e.g., $0.49 \%$ in the 1 lag specification, while a gas price decrease does not lead to AN price decreases. However, the fit of the empirical model is rather weak, with a low R-squared for such time series analysis. Therefore, the results found for AN should be handled with care. Visual inspection of the data seems to suggest that small cost increases are passed through, but large increases may not be. This could be a topic for further work using a different non-linear model specification. 


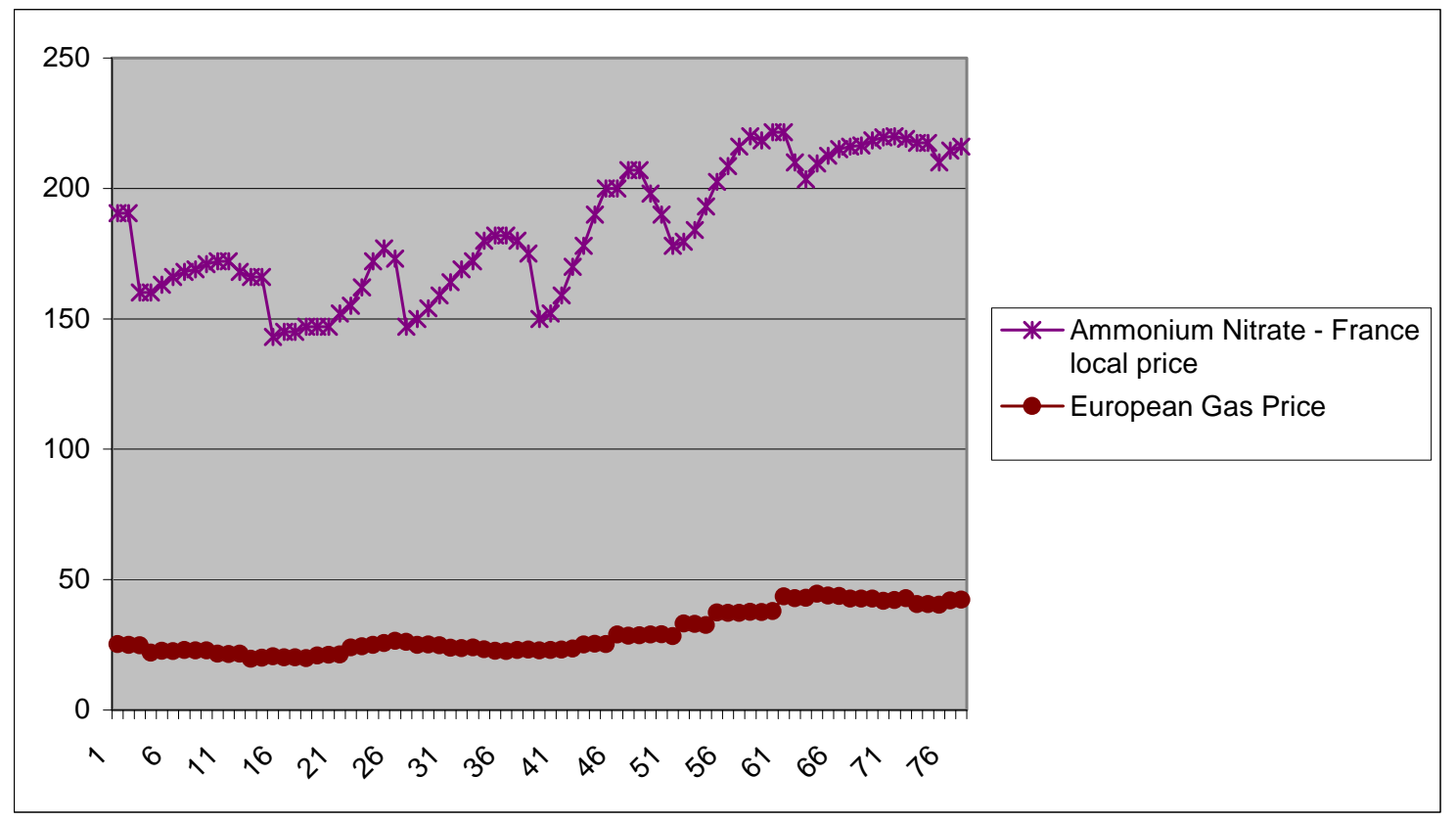

Figure 7 Monthly data EU prices - AN 


\subsection{Results monthly data UK}

For the analysis of UK-specific prices, cost shocks that are UK-specific are of particular relevance, i.e. costs that extra-UK or extra-EU competitors of these sectors would not face. Most relevant in this respect are the (GBP/USD) exchange rate shocks, as well as interest rate, electricity and gas price shocks. These should represent UK-specific cost shocks as interest rate and exchange rate developments with respect to UK interest rates and the GBP/USD exchange rate are, by definition, UK-specific. Electricity and gas price shocks should also be rather UK-specific as gas (Kjärstad and Johnsson, 2007) and electricity prices (Zachmann, 2008) in the UK may often decouple from the price level in continental Europe or in countries outside Europe. However, particularly in cases when the null hypothesis of no pass-through cannot be rejected, estimation results have to be handled with care. Generally, the economic impact of interest rate shocks is highly disputed, so that an absence of interest rate cost pass through may signify the lack of economic relevance of the interest rate, instead of non-ability of cost pass-through of any sector. Economic relevance in this case would depend on the debt levels of firms, which would vary from firm to firm and sector to sector. In the case of electricity prices, rejection of pass-through may be the result of the use of long term electricity contracts by firms, making APX electricity prices a bad proxy of the true electricity costs faced by the sectors analysed. Ability to pass-through costs should be a sign of a positive and statistically significant coefficient for the respective cost shock. One exception to this is the GBP/USD exchange rate. Here a negative sign of the estimated coefficient should indicate ability to pass through costs as an appreciation (depreciation) of the GBP against USD - as indicated by a rise (fall) of the exchange rate - should represent reduced (increased) procurement costs for imported goods.

\section{Hollow glass (Sector DI2613)}

For hollow glass (Table 9), our results do not suggest strong pass-through of the production costs. For hollow glass, we receive evidence for a pass-through of interest rate-induced costs, and - although only weak - evidence for a pass-through of gas costs. According to our point estimates in the specification including one lag, hollow glass price elasticities of up to 0.03 with respect to gas and interest rates. In contrast, there is no evidence of a pass through of any exchange rate, electricity, and oil price-induced costs, with the hollow glass price even falling 
with rising oil prices. Estimations including up to three (Table 29) or five (Table 30) lags give results that barely deviate from these finding. In the light of energy intensities of hollow glass production of $13.55 \%$ (Table 4 ), this would suggest that energy pass-through rates for hollow glass are around 20 to $25 \%$. As energy intensities reported here are calculated as turnover of the respective sectors (i.e. not in respect to total production costs), actual cost pass through rates could be lower than suggested by this calculation.

Table 9 Hollow glass ARDL regression results monthly data (1 lag)

\begin{tabular}{|c|c|}
\hline \multicolumn{2}{|l|}{ Dep. Var.: 4 Hollow Glass } \\
\hline const & $\begin{array}{l}0.00 * * * \\
(0.00)\end{array}$ \\
\hline L1 $\Delta$ Hollow Glass & $\begin{array}{l}0.08 \\
(0.10)\end{array}$ \\
\hline$\Delta$ APX Power UK Spot Base Load Index & $\begin{array}{l}-0.00 * * \\
(0.00)\end{array}$ \\
\hline L1 $\Delta$ APX Power UK Spot Base Load Index & $\begin{array}{l}0.00 \\
(0.00)\end{array}$ \\
\hline$\Delta$ UK Interbank Overnight Middle Rate & $\begin{array}{l}0.01 * * \\
(0.00)\end{array}$ \\
\hline L1 $\Delta$ UK Interbank Overnight Middle Rate & $\begin{array}{l}0.00 \\
(0.00)\end{array}$ \\
\hline$\Delta$ US Dollar to British Pound Sterling exchange rate & $\begin{array}{l}0.01 \\
(0.02)\end{array}$ \\
\hline L1 $\Delta$ US Dollar to British Pound Sterling exchange rate & $\begin{array}{l}0.02 \\
(0.02)\end{array}$ \\
\hline$\Delta$ Brent Crude Oil UK Close & $\begin{array}{l}0.01 \\
(0.01)\end{array}$ \\
\hline L1 $\Delta$ Brent Crude Oil UK Close & $\begin{array}{l}-0.01^{*} \\
(0.00)\end{array}$ \\
\hline$\Delta$ UK large consumer gas & $\begin{array}{l}0.01 * \\
(0.00)\end{array}$ \\
\hline L1 $\Delta$ UK large consumer gas & $\begin{array}{l}0.00 \\
(0.00)\end{array}$ \\
\hline Obs. & 75 \\
\hline R-squared & 0.25 \\
\hline F-Test & 1.22 \\
\hline AIC & -634.93 \\
\hline $\mathrm{BIC}$ & -607.12 \\
\hline
\end{tabular}

Note: White heteroskedasticity-robust standard errors in brackets. *,** and *** show significance at the $10 \%-$, $5 \%$, and 1\%-level, respectively.

Moreover, we do not find any evidence for an asymmetric price transmission from the gas to the UK hollow glass market. The corresponding results of an asymmetric ARDL specification with respect to the gas prices are shown in Table 31 and Table 32. 


\section{Container glass}

For container glass (Table 10), there is no evidence that any of the cost shocks considered are passed through to the consumers. According to our regression results, none of the possible input price change series integrated into our empirical framework - exchange and interest rate, electricity, oil and gas prices - significantly affect container glass revenue changes in the expected direction. This impression is underpinned by specifications considering up to three (Table 33) and five (Table 34) lags of the respective explanatory variables. These regressions moreover suggest that container glass revenues can be better explained by their own dynamics than by input cost shocks. One possible explanation of this finding would be that container glass prices are a function of variables other than those considered here, including demand side variables.

Table 10 Container glass ARDL regression results monthly data (1 lag)

\begin{tabular}{|c|c|}
\hline \multicolumn{2}{|l|}{ Dep. Var.: A Container Glass } \\
\hline const & $\begin{array}{l}-0.00 \\
(0.00)\end{array}$ \\
\hline L1 $\Delta$ Container Glass & $\begin{array}{l}-0.66^{* * * *} \\
(0.13)\end{array}$ \\
\hline$\triangle$ APX Power UK Spot Base Load Index & $\begin{array}{l}-0.02 \\
(0.04)\end{array}$ \\
\hline L1 $\Delta$ APX Power UK Spot Base Load Index & $\begin{array}{l}-0.05 \\
(0.03)\end{array}$ \\
\hline$\Delta$ UK Interbank Overnight Middle Rate & $\begin{array}{l}0.06 \\
(0.06)\end{array}$ \\
\hline L1 $\Delta$ UK Interbank Overnight Middle Rate & $\begin{array}{l}-0.07 \\
(0.05)\end{array}$ \\
\hline$\Delta$ US Dollar to British Pound Sterling exchange rate & $\begin{array}{l}0.34 \\
(0.36)\end{array}$ \\
\hline L1 $\Delta$ US Dollar to British Pound Sterling exchange rate & $\begin{array}{l}0.64 * \\
(0.34)\end{array}$ \\
\hline$\Delta$ Brent Crude Oil UK Close & $\begin{array}{l}0.08 \\
(0.10)\end{array}$ \\
\hline L1 $\Delta$ Brent Crude Oil UK Close & $\begin{array}{l}-0.13^{*} \\
(0.07)\end{array}$ \\
\hline$\Delta$ UK large consumer gas & $\begin{array}{l}0.09 \\
(0.07)\end{array}$ \\
\hline L1 $\Delta$ UK large consumer gas & $\begin{array}{l}0.01 \\
(0.06)\end{array}$ \\
\hline Obs. & 75 \\
\hline R-squared & 0.48 \\
\hline F-Test & $9.05 * * *$ \\
\hline AIC & -172.89 \\
\hline $\mathrm{BIC}$ & -145.08 \\
\hline
\end{tabular}

Note: White heteroskedasticity-robust standard errors in brackets. ${ }^{*},{ }^{*}$ and $* * *$ show significance at the $10 \%$, $5 \%$, and 1\%-level, respectively. None of the specification tests indicates misspecification. 
As for hollow glass, there is moreover no indication for an asymmetric effect of gas prices on container glass revenues. The results reported in Table 35 and Table 36 do not show any statistical significance of the asymmetric gas price variables.

\section{Ceramic goods (Sector DI262)}

For ceramic goods (Table 11), our results indicate only partial pass-through of gas price increases to consumers (cp. also Figure 8). Point estimates in the specification including first lags of the explanatory variables suggest ceramic product price elasticities of 0.07 with respect to gas prices. For all other cost shocks considered - stemming from the money, oil, electricity and foreign exchange market - no evidence for a pass-through on ceramic goods prices has been found. In specifications including longer lag lengths (cp. Table 37 and Table 38), point estimates suggest higher gas price elasticities. From the figure below, it appears that there was a period in which gas prices rose strongly but producers did not pass on the cost increase to consumers, thereby absorbing the cost increase in their profits. This can this be consistent with the finding that firms tended to pass through $>100 \%$ of gas price increases.

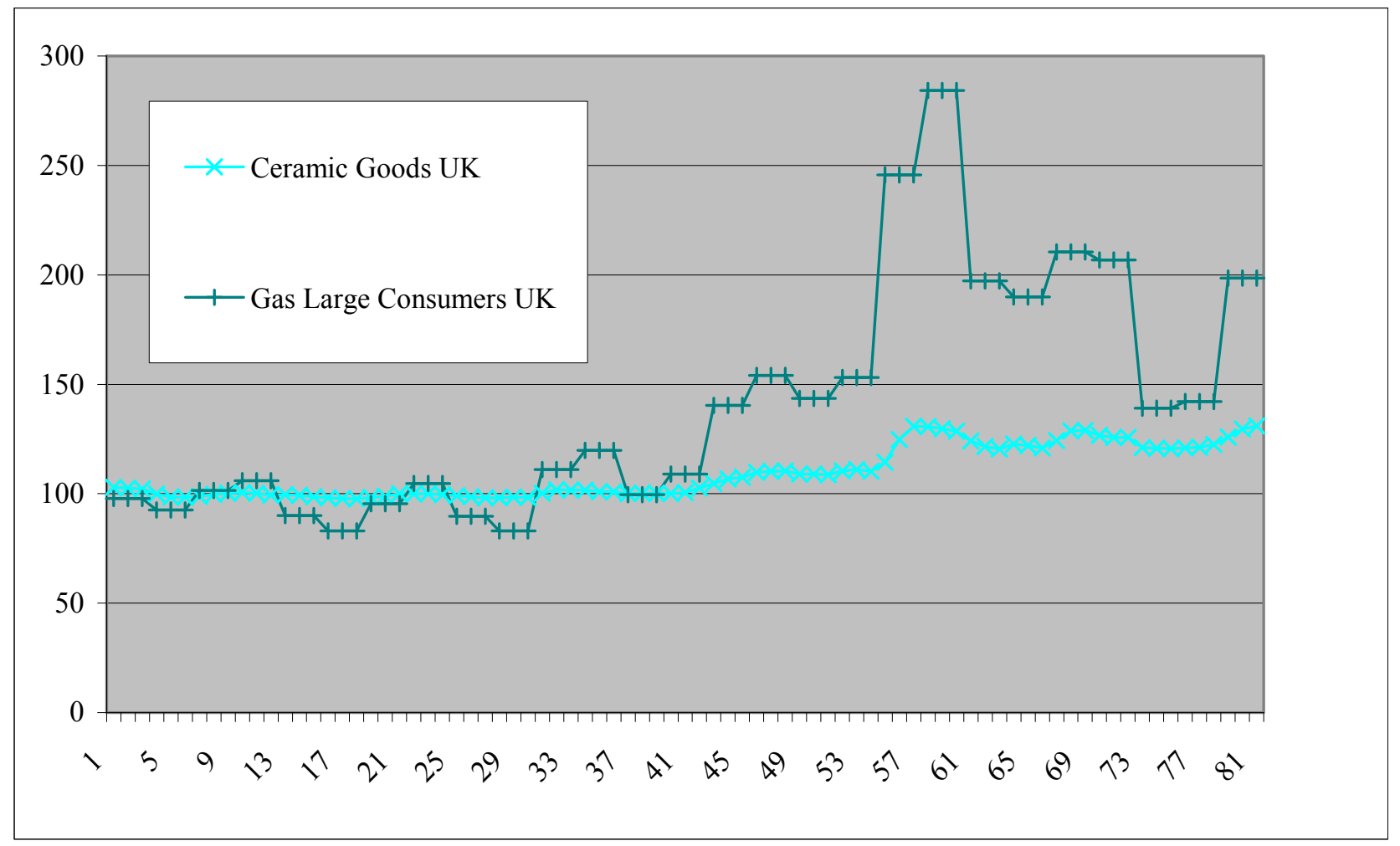

Figure 8 Monthly data UK prices - Ceramic Goods 
In the light of energy intensities of ceramic goods production of $3.35 \%$ (Table 4), this would suggest that energy pass-through rates for ceramic goods of more than $100 \%$.

Table 11 Ceramic goods ARDL regression results monthly data (1 lag)

\begin{tabular}{|c|c|}
\hline \multicolumn{2}{|l|}{ Dep. Var.: $\triangle$ Ceramic Goods } \\
\hline const & $\begin{array}{l}0.00 \\
(0.00)\end{array}$ \\
\hline L1 $\Delta$ Ceramic Goods & $\begin{array}{l}0.25^{* *} \\
(0.11)\end{array}$ \\
\hline$\triangle$ APX Power UK Spot Base Load Index & $\begin{array}{l}0.01 \\
(0.01)\end{array}$ \\
\hline L1 $\Delta$ APX Power UK Spot Base Load Index & $\begin{array}{l}0.00 \\
(0.00)\end{array}$ \\
\hline$\Delta$ UK Interbank Overnight Middle Rate & $\begin{array}{l}-0.00 \\
(0.01)\end{array}$ \\
\hline L1 $\Delta$ UK Interbank Overnight Middle Rate & $\begin{array}{l}-0.00 \\
(0.01)\end{array}$ \\
\hline$\Delta$ US Dollar to British Pound Sterling exchange rate & $\begin{array}{l}-0.05 \\
(0.04)\end{array}$ \\
\hline L1 $\Delta$ US Dollar to British Pound Sterling exchange rate & $\begin{array}{l}-0.09 \\
(0.07)\end{array}$ \\
\hline$\Delta$ Brent Crude Oil UK Close & $\begin{array}{l}-0.03 * \\
(0.02)\end{array}$ \\
\hline L1 $\Delta$ Brent Crude Oil UK Close & $\begin{array}{l}-0.02 * \\
(0.01)\end{array}$ \\
\hline$\Delta$ UK large consumer gas & $\begin{array}{l}0.07 * * * \\
(0.01)\end{array}$ \\
\hline L1 $\Delta$ UK large consumer gas & $\begin{array}{l}0.05 \\
(0.03)\end{array}$ \\
\hline Obs. & 75 \\
\hline R-squared & 0.60 \\
\hline F-Test & $9.36 * * *$ \\
\hline AIC & -444.60 \\
\hline $\mathrm{BIC}$ & -416.79 \\
\hline
\end{tabular}

Note: White heteroskedasticity-robust standard errors in brackets. ${ }^{*},{ }^{*}$ and ${ }^{* * *}$ show significance at the $10 \%-$, $5 \%$, and $1 \%$-level, respectively. None of the specification tests indicates misspecification.

What is more, we receive empirical evidence of an asymmetric gas price pass-through to UK ceramic goods prices. Point estimates from asymmetric specifications including one (Table 39) and three (Table 40) lags of all explanatory variables suggest a change in ceramic goods price increase of up to $0.33 \%$ against the background of a $1 \%$ increase in gas price changes, while they indicate that a gas price change decrease by $1 \%$ is only followed by a ceramics goods price change decrease of $0.07 \%$. 


\section{Ceramic bricks (Non-refractory ceramic building bricks, flooring blocks, supp; sector}

DI26400)

For ceramic bricks (Table 12), our results also indicate the pass-through of only (at least parts of) gas price increases to the consumers. Point estimates in the specification including first lags of the explanatory variables suggest ceramic bricks price elasticities of 0.01 with respect to gas prices. Also, interest rate changes seem to be passed on through ceramic bricks prices, with point estimates suggesting elasticities of 0.02 . For cost shocks stemming from the oil, electricity and foreign exchange market no evidence for a pass-through has been found. In specifications including longer lag lengths (cp. Table 41 and Table 42), point estimates suggest a gas price elasticity of up to 0.05 .

In light of energy intensities of ceramic goods production of $12.86 \%$ (Table 4), this would suggest energy pass-through rates for ceramic bricks of 30 to $40 \%$. In comparison to ceramic goods, the result suggests that there are significant differences in pass-through behaviour across the ceramics sector. The fact that pass-through seems to be easier for ceramic goods than for ceramic bricks may be rooted in the fact that product differentiation may be more difficult for a relatively homogenous goods, such as those found in the ceramic bricks subsector, in comparison with rather heterogeneous goods produced in the ceramic goods sector. 
Table 12 Ceramic bricks ARDL regression results monthly data (1 lag)

\begin{tabular}{|l|l|}
\hline Dep. Var.: $\Delta$ Ceramic Bricks & $0.00^{* * *}$ \\
\hline Const & $(0.00)$ \\
L1 $\Delta$ Ceramic Bricks & $-0.29^{* *}$ \\
$\Delta$ APX Power UK Spot Base Load Index & $(0.11)$ \\
L1 $\Delta$ APX Power UK Spot Base Load Index & -0.01 \\
& $(0.01)$ \\
$\Delta$ UK Interbank Overnight Middle Rate & 0.00 \\
& $(0.00)$ \\
L1 $\Delta$ UK Interbank Overnight Middle Rate & $0.01^{*}$ \\
$\Delta$ US Dollar to British Pound Sterling exchange rate & $(0.01)$ \\
& $0.01^{*}$ \\
L1 $\Delta$ US Dollar to British Pound Sterling exchange rate & $0.01)$ \\
$\Delta$ Brent Crude Oil UK Close & 0.03 \\
L1 $\Delta$ Brent Crude Oil UK Close & $(0.05)$ \\
$\Delta$ UK large consumer gas & -0.04 \\
& $(0.06)$ \\
L1 $\Delta$ UK large consumer gas & 0.01 \\
& $(0.01)$ \\
Obs. & -0.01 \\
R-squared & $(0.01)$ \\
AIC & 0.00 \\
BIC & $(0.01)$ \\
\hline Note: White het & $0.01^{*}$ \\
\hline
\end{tabular}

Note: White heteroskedasticity-robust standard errors in brackets. ${ }^{*}, * *$ and ${ }^{* * *}$ show significance at the $10 \%-$, $5 \%-$, and 1\%-level, respectively. None of the specification tests indicates misspecification.

In contrast to ceramic goods, however, we have not seen empirical evidence of an asymmetric gas price pass-through to UK ceramic bricks prices (Table 43 and Table 44). 


\section{Conclusion}

This paper should enable policy makers to further their understanding in the area of ability to pass through costs. The paper provides evidence about which of the sectors analysed can pass on increased costs as a result of the European Union Emissions Trading Scheme (EU ETS) whilst maintaining global competitiveness. Table 13 below provides a summary of the results obtained.

We conduct an empirical analysis of cost pass-through ability of producers of selected products within the sectors refineries, glass, chemicals and ceramics. For this purpose, we link selected output prices of these sectors from the UK or the European market to input price series in order to assess whether input price shocks can be passed on to the consumers or, alternatively, have to be borne by the producers themselves. The products analysed are the following: OPAL UK Diesel and Gasoline for parts of the oil industry, hollow glass and container glass as outputs of parts of the UK Glass industry, low density polyethylene film (LDPE) and ammonium nitrate as outputs of parts of the EU / UK chemical industry, as well as a ceramic goods and a ceramic bricks series representing output of a part of the UK ceramics industry. For the purpose of analysing pass-through of carbon costs, the availability of weekly data on sectoral output prices is absolutely necessary. This is due to the fact that the EU ETS is still in an early stage and time series for carbon prices are therefore relatively short particularly if less frequent data is used. As weekly output price data is only available for the UK refining industry, we can directly assess carbon cost pass through only for selected products of this sector. For outputs representing parts of the industries glass, chemicals and ceramics, pass through analysis is only possible for shocks of costs other than carbon costs. The ability of passing through such costs should serve as a proxy for the ability to pass through carbon costs. Moreover, asymmetric price transmission with respect to the prices of important input factors is examined. Although asymmetric price transmission is often associated with price setting and therefore market power of the respective producer, this is not the only theoretical justification to the phenomenon of asymmetric cost pass-through. Other explanations include menu costs as well as accountancy rules and inventory valuation (Meyer and von Cramon-Taubadel, 2004) 
Table 13 Estimates of rate of cost pass through for all sectors.

\begin{tabular}{|c|c|c|c|c|c|}
\hline $\begin{array}{l}\text { Sector and } \\
\text { Product }\end{array}$ & $\begin{array}{l}\text { Energy } \\
\text { intensity }\end{array}$ & $\begin{array}{c}\text { Estimated } \\
\text { Pass } \\
\text { through } \\
\text { rate }\end{array}$ & $\begin{array}{c}\text { Asymmetric } \\
\text { pricing? }\end{array}$ & $\begin{array}{c}\text { Other } \\
\text { factors? }\end{array}$ & $\begin{array}{c}\text { Data } \\
\text { periodicity } \\
\text { and time } \\
\text { period }\end{array}$ \\
\hline $\begin{array}{l}\text { Refineries, } \\
\text { UK diesel }\end{array}$ & 60 percent & $\begin{array}{l}50 \text { percent } \\
\text { over five } \\
\text { weeks. }\end{array}$ & No & $\begin{array}{l}\text { Very } \\
\text { robust } \\
\text { results }\end{array}$ & $\begin{array}{l}\text { Weekly, } \\
\text { January } \\
2005- \\
\text { December } \\
2006 .\end{array}$ \\
\hline $\begin{array}{l}\text { Refineries, } \\
\text { UK } \\
\text { gasoline }\end{array}$ & 60 percent & $\begin{array}{l}75 \text { percent } \\
\text { over five } \\
\text { weeks }\end{array}$ & No. & $\begin{array}{l}\text { Very } \\
\text { robust } \\
\text { results }\end{array}$ & $\begin{array}{l}\text { Weekly, } \\
\text { January } \\
2005- \\
\text { December } \\
2006\end{array}$ \\
\hline UK, LDPE & 32 percent & $\begin{array}{l}100 \text { percent } \\
\text { over one } \\
\text { month }\end{array}$ & No. & $\begin{array}{l}\text { Robust, } \\
\text { but other } \\
\text { variables } \\
\text { used as a } \\
\text { proxy for } \\
\text { EUA price. }\end{array}$ & $\begin{array}{l}\text { Monthly, } \\
\text { April } 2001 \\
\text { to } \\
\text { December } \\
2007\end{array}$ \\
\hline $\mathrm{UK}, \mathrm{AN}$ & 66 percent & $\begin{array}{lr}50 \text { percent } \\
\text { over six } \\
\text { months }\end{array}$ & Yes & $\begin{array}{l}\text { Low } \\
\text { degree of } \\
\text { fit. }\end{array}$ & $\begin{array}{l}\text { Monthly, } \\
\text { April } 2001 \\
\text { to } \\
\text { December } \\
2007\end{array}$ \\
\hline $\begin{array}{l}\text { UK, } \\
\text { Hollow } \\
\text { Glass }\end{array}$ & $\begin{array}{l}13.55 \\
\text { percent }\end{array}$ & $\begin{array}{l}20-25 \\
\text { percent over } \\
\text { six months. }\end{array}$ & No & $\begin{array}{l}\text { Moderate } \\
\text { degree of } \\
\text { fit. }\end{array}$ & $\begin{array}{l}\text { Monthly, } \\
\text { April } 2001 \\
\text { to } \\
\text { December } \\
2007 \text {. }\end{array}$ \\
\hline $\begin{array}{l}\text { UK } \\
\text { container } \\
\text { glass }\end{array}$ & $\begin{array}{l}6.13^{2} \\
\text { percent }\end{array}$ & $\begin{array}{l}\text { No evidence } \\
\text { of cost pass- } \\
\text { through }\end{array}$ & No. & Robust & $\begin{array}{l}\text { Monthly, } \\
\text { April } 2001 \\
\text { to } \\
\text { December } \\
2007 \text {. }\end{array}$ \\
\hline $\begin{array}{l}\text { UK } \\
\text { Ceramic } \\
\text { goods }\end{array}$ & $\begin{array}{l}3.35 \\
\text { percent }\end{array}$ & $\begin{array}{l}\text { Greater than } \\
100 \text { percent. }\end{array}$ & Yes & $\begin{array}{l}\text { High } \\
\text { degree of } \\
\text { fit. }\end{array}$ & $\begin{array}{l}\text { Monthly, } \\
\text { April } 2001 \\
\text { to } \\
\text { December } \\
2007 \text {. }\end{array}$ \\
\hline $\begin{array}{l}\text { Ceramic } \\
\text { Bricks }\end{array}$ & $\begin{array}{l}12.86 \\
\text { percent }\end{array}$ & $\begin{array}{l}30-40 \\
\text { percent over } \\
\text { six months. }\end{array}$ & No & $\begin{array}{l}\text { Moderate } \\
\text { degree of } \\
\text { fit. }\end{array}$ & $\begin{array}{l}\text { Monthly, } \\
\text { April 2001 } \\
\text { to } \\
\text { December } \\
2007 \text {. }\end{array}$ \\
\hline
\end{tabular}

\footnotetext{
${ }^{2}$ Energy intensity for manufacture of glass and glass products.
} 
Our results suggest that at least parts of the carbon costs have been passed on to diesel and gasoline consumers by their producers and / or retailers. There is not reason to believe that this effect may be explained by electricity prices (including EUA prices passed through by electricity generators) faced by the UK refining industry. Gas prices as the most relevant electricity-related variable is included in the analysis, and results are also extremely robust to the inclusion of UK electricity prices (results available on request). In contrast to existing evidence for the German power sector, there is no evidence for an asymmetric pass-through of carbon costs by the UK oil industry. For the products analysed that are produced by parts of the glass industry pass-through of production cost is rather a puzzle. Regression analysis for UK container glass revenues does not indicate any statistically significant relationship to input prices considered, and suggests that those prices or, respectively, revenues, are rather driven by their own time series dynamics. For hollow glass some - although no asymmetric pass through of gas prices seems possible. However, it has to be specified that hollow glass data represents products defined under hollow glass which include not only container glass as made in the UK but also products which are in effect hollow but are made by different process. These products include tableware products such as drinking glasses and hollow products made from pre-manufactured glass tubing, however, manufacture is not available in the UK, i.e., these products are imported into the UK.

Our results for ceramic goods give a different picture: Pass-through (at least of parts of) gas price shocks that are UK-specific is, to a certain extent, possible, with ceramic goods prices "rising faster than they fall", i.e., showing an asymmetric relationship to gas prices. For ceramic bricks, symmetric pass through of parts of the gas price is shown. Also for subsectors of the chemical industry pass-through behaviour is analysed with respect to different output prices. The European low density polyethylene film industry is shown to pass through naphtha prices. The relationship between naphtha and LDPE prices does not appear to be asymmetric, however. The same holds true for the relationship between EU ammonium nitrate and gas prices. While, however, gas prices may be region-specific to a certain extent, this does not necessarily hold for naphtha prices. The pass-through ability of sectors with respect to country- or region-specific energy prices should serve as an indication for the passthrough ability with respect to carbon costs under an auctioning-regime of the EU ETS which are region-specific, as well. 
These results provide new insights into the debate on the ability of pass-through of costs generated by the EU Emission Trading Scheme. They suggest that some of the sectors analysed have the ability to pass through a portion of their carbon costs to the consumers. However, our results indicate that the sectors cannot achieve a complete pass-through of their costs into output prices, with the exception of ceramic goods. Moreover, although generally accepted as an important indicator for competitiveness implications of EU ETS, the ability of sectors to pass-through costs also has its limits. Particularly, longer term impacts of sectors and firms attempting to passing through carbon costs, and the consequences for leakage remain uncertain. From a technical perspective, the identification of long-run relationships (so-called cointegration, Engle and Granger, 1987) within the framework of the empirical approach as well as variations in the control variables used in the estimations could provide additional robustness checks. Still, it has to be emphasised that only selected products of the sectors refineries, glass, chemicals and ceramics have been analysed in this paper. In order to provide fully representative information about the ability to pass through carbon costs of those sectors in general, additional analyses for all products of these sectors would be needed. Therefore, the analysis of further outputs of the sectors covered by this paper remains for future research. Apart from that, the application of numerical models taking into account estimated pass-through rates and linking this to market shares in relation to extra-EU competitors could provide additional insights into the long-run competitiveness effects of the scheme. 


\section{References}

Bai, J. and P. Perron (1998), Estimating and Testing Linear Models with Multiple Structural Changes, Econometrica 66, 47-78.

Borenstein, S., A.C. Cameron, and R. Gilbert (1997), Do Gasoline Prices Respond Asymmetrically to Crude Oil Price Changes? Quarterly Journal of Economics 112, 305-39.

Brown, S.P.A. and M.K. Yücel (2000), Gasoline and Crude Oil Prices: Why the Asymmetry? Economic and Financial Policy Review 3, 23-29.

Ecfin (2007), Imposing a Unilateral Carbon Constraint on Energy-Intensive Industries and its Impact on International Competitiveness - Data \& Analysis, Report, Brussels.

Engle, R.F. and C.W.J. Granger (1987), Co-Integration and Error Correction: Representation, Estimation, and Testing, Econometrica 55, 251-276.

Europia (2008), Work Programme of DG Enterprise EII Task Force, Communication, Brussels.

Frey, G. and M. Manera (2007), Econometric Models of Asymmetric Price Transmission, Journal of Economic Surveys 21, 349-415.

Granger, C.W.J. and P. Newbold (1974), Spurious Regressions in Econometrics, Journal of Econometrics 2, 111-120.

Greene, W. (2003), Econometric Analysis, Prentice Hall, Fifth Edition.

Hepburn, C., Grubb, M., Neuhoff, K., Matthes, F., and M. Tse (2006), Auctioning of EU ETS phase II allowances: How and why? Climate Policy 6, 137-160. 
Hourcade, J.-C., Demailly, D., Neuhoff, K. and M. Sato, Differentaition and Dynamics of EU ETS Industrial Competitiveness Impacts, Report, Climate Strategies, Cambridge.

Kjärstad, J. and F. Johnsson (2007), Prospects of the European Gas Market, Energy Policy 35, 869-888.

Meyer, J. and S. von Cramon-Taubadel (2004), Asymmetric Price Transmission: A Survey, Journal of Agricultural Economics 55, 581-611.

Neuhoff, K. and F.C. Matthes (2008), The Role of Auctions for Emissions Trading, Climate Strategies, Cambridge.

Oberndorfer, U. (forthcoming), EU Emission Allowances and the Stock Market: Evidence from the Electricity Industry, Ecological Economics.

Oberndorfer, U. and K. Rennings (2007), Costs and Competitiveness Effects of the European Union Emissions Trading Scheme, European Environment 17, 1-17.

Peltzman, S. (2000), Prices Rise Faster than they Fall, Journal of Political Economy 108, 466502.

Sarrel, S. and J. Sijm (2003), Carbon Trading in the Policy Mix, Oxford Review of Economic Policy 19, 420-437.

Sijm, J., K. Neuhoff, and Y. Chen (2006), CO2 Cost Pass-Through and Windfall Profits in the Power Sector, Climate Policy 6, 49-72.

Walker, N. (2008), The Impact of CO2 Emissions Trading on the European Cement Industry, Dissertation, University College Dublin.

Zachmann, G. (2008), Electricity wholesale market prices in Europe: Convergence? Energy Economics 30, 1659-1671. 
Zachmann, G. and C. v. Hirschhausen (2008), First Evidence of Asymmetric Cost Passthrough of EU Emissions Allowances: Examining Wholesale Electricity Prices in Germany, Economics Letters 99, 465-469. 


\section{Appendix}

\section{OPAL UK Diesel}

Table 13 Diesel ARDL regression results weekly data (3 lags)

\begin{tabular}{|c|c|}
\hline \multicolumn{2}{|l|}{ Dep. Var.: $\triangle$ OPAL UK Diesel } \\
\hline const & $\begin{array}{l}0.00 \\
(0.00)\end{array}$ \\
\hline L1 $\Delta$ OPAL UK Diesel & $\begin{array}{l}0.30 * * \\
(0.15)\end{array}$ \\
\hline L2 $\Delta$ OPAL UK Diesel & $\begin{array}{l}0.11 \\
(0.11)\end{array}$ \\
\hline L3 $\Delta$ OPAL UK Diesel & $\begin{array}{l}0.06 \\
(0.09)\end{array}$ \\
\hline$\Delta$ EU Emission Allowance & $\begin{array}{l}-0.00 \\
(0.01)\end{array}$ \\
\hline L1 $\Delta$ EU Emission Allowance & $\begin{array}{l}0.02 * * * \\
(0.01)\end{array}$ \\
\hline L2 $\Delta$ EU Emission Allowance & $\begin{array}{l}0.01 \\
(0.01)\end{array}$ \\
\hline L3 $\Delta$ EU Emission Allowance & $\begin{array}{l}0.00 \\
(0.01)\end{array}$ \\
\hline$\Delta$ UK Interbank Overnight Middle Rate & $\begin{array}{l}-0.02 \\
(0.04)\end{array}$ \\
\hline L1 $\Delta$ UK Interbank Overnight Middle Rate & $\begin{array}{l}0.02 \\
(0.04)\end{array}$ \\
\hline L2 $\Delta$ UK Interbank Overnight Middle Rate & $\begin{array}{l}-0.02 \\
(0.04)\end{array}$ \\
\hline L3 $\Delta$ UK Interbank Overnight Middle Rate & $\begin{array}{l}-0.02 \\
(0.05)\end{array}$ \\
\hline$\Delta$ US Dollar to British Pound Sterling exchange rate & $\begin{array}{l}0.02 \\
(0.10)\end{array}$ \\
\hline L1 $\Delta$ US Dollar to British Pound Sterling exchange rate & $\begin{array}{l}0.21^{*} \\
(0.12)\end{array}$ \\
\hline L2 $\Delta$ US Dollar to British Pound Sterling exchange rate & $\begin{array}{l}-0.12 \\
(0.11)\end{array}$ \\
\hline L3 $\Delta$ US Dollar to British Pound Sterling exchange rate & $\begin{array}{l}-0.16 \\
(0.11)\end{array}$ \\
\hline$\Delta$ Brent Crude Oil UK Close & $\begin{array}{l}-0.02 \\
(0.03)\end{array}$ \\
\hline L1 $\Delta$ Brent Crude Oil UK Close & $\begin{array}{l}0.06 * \\
(0.03)\end{array}$ \\
\hline L2 $\Delta$ Brent Crude Oil UK Close & $\begin{array}{l}0.09 * * * \\
(0.03)\end{array}$ \\
\hline L3 $\Delta$ Brent Crude Oil UK Close & $\begin{array}{l}0.10 * * * \\
(0.03)\end{array}$ \\
\hline$\Delta 1$ Month Forward Natural Gas & $\begin{array}{l}-0.00 \\
(0.01)\end{array}$ \\
\hline L1 $\Delta 1$ Month Forward Natural Gas & $\begin{array}{l}0.01 \\
(0.01)\end{array}$ \\
\hline L2 $\Delta 1$ Month Forward Natural Gas & $\begin{array}{l}0.00 \\
(0.01)\end{array}$ \\
\hline L3 $\Delta 1$ Month Forward Natural Gas & $\begin{array}{l}-0.01 \\
(0.01)\end{array}$ \\
\hline Obs. & 104 \\
\hline R-squared & 0.60 \\
\hline F-Test & $8.43 * * *$ \\
\hline AIC & -619.26 \\
\hline $\mathrm{BIC}$ & -555.80 \\
\hline
\end{tabular}

Note: White heteroskedasticity-robust standard errors in brackets. *, ** and *** show significance at the 10\%-, 5\%-, and 1\%-level, respectively. None of the specification tests indicates misspecification. 
Table 14 Diesel ARDL regression results weekly data (5 lags)

\begin{tabular}{|c|c|}
\hline \multicolumn{2}{|l|}{ Dep. Var.: $\triangle$ OPAL UK Diesel } \\
\hline const & $\begin{array}{l}0.00 \\
(0.00)\end{array}$ \\
\hline L1 $\Delta$ OPAL UK Diesel & $\begin{array}{l}0.28^{*} \\
(0.16)\end{array}$ \\
\hline L2 $\Delta$ OPAL UK Diesel & $\begin{array}{l}0.08 \\
(0.12)\end{array}$ \\
\hline L3 $\Delta$ OPAL UK Diesel & $\begin{array}{l}-0.01 \\
(0.13)\end{array}$ \\
\hline L4 $\Delta$ OPAL UK Diesel & $\begin{array}{l}0.07 \\
(0.11)\end{array}$ \\
\hline L5 $\Delta$ OPAL UK Diesel & $\begin{array}{l}-0.04 \\
(0.09)\end{array}$ \\
\hline$\Delta$ EU Emission Allowance & $\begin{array}{l}0.00 \\
(0.01)\end{array}$ \\
\hline L1 $\Delta$ EU Emission Allowance & $\begin{array}{l}0.02 * \\
(0.01)\end{array}$ \\
\hline L2 $\Delta$ EU Emission Allowance & $\begin{array}{l}0.01 \\
(0.01)\end{array}$ \\
\hline L3 $\Delta$ EU Emission Allowance & $\begin{array}{l}0.01 \\
(0.01)\end{array}$ \\
\hline L4 $\Delta$ EU Emission Allowance & $\begin{array}{l}0.01 \\
(0.01)\end{array}$ \\
\hline L5 $\Delta$ EU Emission Allowance & $\begin{array}{l}0.01 \\
(0.01)\end{array}$ \\
\hline$\Delta$ UK Interbank Overnight Middle Rate & $\begin{array}{l}-0.02 \\
(0.04)\end{array}$ \\
\hline L1 $\Delta$ UK Interbank Overnight Middle Rate & $\begin{array}{l}0.01 \\
(0.06)\end{array}$ \\
\hline L2 $\Delta$ UK Interbank Overnight Middle Rate & $\begin{array}{l}-0.05 \\
(0.05)\end{array}$ \\
\hline L3 $\Delta$ UK Interbank Overnight Middle Rate & $\begin{array}{l}-0.03 \\
(0.07)\end{array}$ \\
\hline L4 $\Delta$ UK Interbank Overnight Middle Rate & $\begin{array}{l}0.00 \\
(0.07)\end{array}$ \\
\hline L5 $\Delta$ UK Interbank Overnight Middle Rate & $\begin{array}{l}-0.09 * * \\
(0.04)\end{array}$ \\
\hline$\Delta$ US Dollar to British Pound Sterling exchange rate & $\begin{array}{l}0.09 \\
(0.11)\end{array}$ \\
\hline L1 $\Delta$ US Dollar to British Pound Sterling exchange rate & $\begin{array}{l}0.19 \\
(0.14)\end{array}$ \\
\hline L2 $\Delta$ US Dollar to British Pound Sterling exchange rate & $\begin{array}{l}-0.12 \\
(0.14)\end{array}$ \\
\hline L3 $\Delta$ US Dollar to British Pound Sterling exchange rate & $\begin{array}{l}-0.09 \\
(0.12)\end{array}$ \\
\hline L4 $\Delta$ US Dollar to British Pound Sterling exchange rate & $\begin{array}{l}0.07 \\
(0.12)\end{array}$ \\
\hline L5 $\Delta$ US Dollar to British Pound Sterling exchange rate & $\begin{array}{l}-0.07 \\
(0.13)\end{array}$ \\
\hline$\Delta$ Brent Crude Oil UK Close & $\begin{array}{l}0.01 \\
(0.05)\end{array}$ \\
\hline L1 $\Delta$ Brent Crude Oil UK Close & $\begin{array}{l}0.04 \\
(0.04)\end{array}$ \\
\hline L2 $\Delta$ Brent Crude Oil UK Close & $\begin{array}{l}0.11 * * * \\
(0.04)\end{array}$ \\
\hline L3 $\Delta$ Brent Crude Oil UK Close & $\begin{array}{l}0.08 * * * \\
(0.03)\end{array}$ \\
\hline L4 $\Delta$ Brent Crude Oil UK Close & $\begin{array}{l}0.02 \\
(0.03)\end{array}$ \\
\hline L5 $\Delta$ Brent Crude Oil UK Close & $\begin{array}{l}0.01 \\
(0.03)\end{array}$ \\
\hline$\Delta 1$ Month Forward Natural Gas & $\begin{array}{l}-0.00 \\
(0.02)\end{array}$ \\
\hline L1 $\Delta 1$ Month Forward Natural Gas & $\begin{array}{l}0.01 \\
(0.01)\end{array}$ \\
\hline L2 $\Delta 1$ Month Forward Natural Gas & $\begin{array}{l}-0.01 \\
(0.01)\end{array}$ \\
\hline L3 $\Delta 1$ Month Forward Natural Gas & $\begin{array}{l}-0.01 \\
(0.01)\end{array}$ \\
\hline L4 $\Delta 1$ Month Forward Natural Gas & -0.01 \\
\hline
\end{tabular}




\begin{tabular}{|l|l|} 
& $(0.01)$ \\
L5 $\mathbf{~ 1}$ Month Forward Natural Gas & 0.01 \\
\hline Obs. & $(0.01)$ \\
R-squared & 102 \\
F-Test & 0.65 \\
AIC & $8.76^{* * *}$ \\
BIC & -595.80 \\
\hline
\end{tabular}

Note: White heteroskedasticity-robust standard errors in brackets. ${ }^{*},{ }^{*}$ and ${ }^{* * *}$ show significance at the $10 \%-, 5 \%-$, and $1 \%$-level, respectively. None of the specification tests indicates misspecification.

Table 15 Diesel ARDL regression results weekly data, asymmetry EUA (1 lag)

\begin{tabular}{|c|c|}
\hline \multicolumn{2}{|l|}{ Dep. Var.: $\triangle$ OPAL UK Diesel } \\
\hline const & $\begin{array}{l}0.00 \\
(0.00)\end{array}$ \\
\hline L1 $\triangle$ OPAL UK Diesel & $\begin{array}{l}0.59^{* * * *} \\
(0.10)\end{array}$ \\
\hline$\Delta$ EU Emission Allowance Positive & $\begin{array}{l}-0.02 \\
(0.02)\end{array}$ \\
\hline L1 $\Delta$ EU Emission Allowance Positive & $\begin{array}{l}0.05 \\
(0.04)\end{array}$ \\
\hline$\Delta$ EU Emission Allowance Negative & $\begin{array}{l}0.01 \\
(0.01)\end{array}$ \\
\hline L1 $\Delta$ EU Emission Allowance Negative & $\begin{array}{l}0.02 * \\
(0.01)\end{array}$ \\
\hline$\Delta$ UK Interbank Overnight Middle Rate & $\begin{array}{l}-0.03 \\
(0.03)\end{array}$ \\
\hline L1 $\Delta$ UK Interbank Overnight Middle Rate & $\begin{array}{l}0.02 \\
(0.04)\end{array}$ \\
\hline$\Delta$ US Dollar to British Pound Sterling exchange rate & $\begin{array}{l}0.05 \\
(0.09)\end{array}$ \\
\hline L1 $\Delta$ US Dollar to British Pound Sterling exchange rate & $\begin{array}{l}0.20^{*} \\
(0.12)\end{array}$ \\
\hline$\Delta$ Brent Crude Oil UK Close & $\begin{array}{l}-0.02 \\
(0.03)\end{array}$ \\
\hline L1 $\Delta$ Brent Crude Oil UK Close & $\begin{array}{l}0.05 \\
(0.04)\end{array}$ \\
\hline$\Delta 1$ Month Forward Natural Gas & $\begin{array}{l}0.00 \\
(0.01)\end{array}$ \\
\hline L1 $\Delta 1$ Month Forward Natural Gas & $\begin{array}{l}0.00 \\
(0.01)\end{array}$ \\
\hline Obs. & 106 \\
\hline R-squared & 0.47 \\
\hline F-Test & $8.79 * * *$ \\
\hline $\mathrm{AIC}$ & -619.92 \\
\hline $\mathrm{BIC}$ & -582.63 \\
\hline
\end{tabular}

Note: White heteroskedasticity-robust standard errors in brackets. ${ }^{*},{ }^{*}$ and ${ }^{* * *}$ show significance at the $10 \%-, 5 \%-$ and $1 \%$-level, respectively. None of the specification tests indicates misspecification. 
Table 16 Diesel ARDL regression results weekly data, asymmetry EUA (3 lags)

\begin{tabular}{|c|c|}
\hline \multicolumn{2}{|l|}{ Dep. Var.: $\triangle$ OPAL UK Diesel } \\
\hline const & $\begin{array}{l}0.00 \\
(0.00)\end{array}$ \\
\hline L1 $\triangle$ OPAL UK Diesel & $\begin{array}{l}0.34 * * \\
(0.15)\end{array}$ \\
\hline L2 $\triangle$ OPAL UK Diesel & $\begin{array}{l}0.07 \\
(0.12)\end{array}$ \\
\hline L3 $\triangle$ OPAL UK Diesel & $\begin{array}{l}0.08 \\
(0.11)\end{array}$ \\
\hline$\Delta$ EU Emission Allowance Positive & $\begin{array}{l}-0.02 \\
(0.03)\end{array}$ \\
\hline L1 $\Delta$ EU Emission Allowance Positive & $\begin{array}{l}0.03 \\
(0.03)\end{array}$ \\
\hline L2 $\Delta$ EU Emission Allowance Positive & $\begin{array}{l}-0.00 \\
(0.03)\end{array}$ \\
\hline L3 $\Delta$ EU Emission Allowance Positive & $\begin{array}{l}0.02 \\
(0.02)\end{array}$ \\
\hline$\Delta$ EU Emission Allowance Negative & $\begin{array}{l}0.01 \\
(0.01)\end{array}$ \\
\hline L1 $\Delta$ EU Emission Allowance Negative & $\begin{array}{l}0.02 * \\
(0.01)\end{array}$ \\
\hline L2 $\Delta$ EU Emission Allowance Negative & $\begin{array}{l}0.00 \\
(0.01)\end{array}$ \\
\hline L3 $\Delta$ EU Emission Allowance Negative & $\begin{array}{l}0.00 \\
(0.02)\end{array}$ \\
\hline$\Delta$ UK Interbank Overnight Middle Rate & $\begin{array}{l}-0.02 \\
(0.04)\end{array}$ \\
\hline L1 $\Delta$ UK Interbank Overnight Middle Rate & $\begin{array}{l}0.02 \\
(0.04)\end{array}$ \\
\hline L2 $\Delta$ UK Interbank Overnight Middle Rate & $\begin{array}{l}-0.02 \\
(0.04)\end{array}$ \\
\hline L3 $\Delta$ UK Interbank Overnight Middle Rate & $\begin{array}{l}-0.02 \\
(0.05)\end{array}$ \\
\hline$\Delta$ US Dollar to British Pound Sterling exchange rate & $\begin{array}{l}0.02 \\
(0.09)\end{array}$ \\
\hline L1 $\Delta$ US Dollar to British Pound Sterling exchange rate & $\begin{array}{l}0.21^{*} \\
(0.12)\end{array}$ \\
\hline L2 $\Delta$ US Dollar to British Pound Sterling exchange rate & $\begin{array}{l}-0.12 \\
(0.13)\end{array}$ \\
\hline L3 $\Delta$ US Dollar to British Pound Sterling exchange rate & $\begin{array}{l}-0.16 \\
(0.11)\end{array}$ \\
\hline$\Delta$ Brent Crude Oil UK Close & $\begin{array}{l}-0.01 \\
(0.03)\end{array}$ \\
\hline L1 $\Delta$ Brent Crude Oil UK Close & $\begin{array}{l}0.06 \\
(0.04)\end{array}$ \\
\hline L2 $\Delta$ Brent Crude Oil UK Close & $\begin{array}{l}0.10 * * * \\
(0.03)\end{array}$ \\
\hline L3 $\Delta$ Brent Crude Oil UK Close & $\begin{array}{l}0.09 * * * \\
(0.03)\end{array}$ \\
\hline$\Delta 1$ Month Forward Natural Gas & $\begin{array}{l}-0.00 \\
(0.01)\end{array}$ \\
\hline L1 $\Delta 1$ Month Forward Natural Gas & $\begin{array}{l}0.01 \\
(0.01)\end{array}$ \\
\hline L2 $\Delta 1$ Month Forward Natural Gas & $\begin{array}{l}0.00 \\
(0.01)\end{array}$ \\
\hline L3 $\Delta 1$ Month Forward Natural Gas & $\begin{array}{l}-0.01 \\
(0.01)\end{array}$ \\
\hline Obs. & 104 \\
\hline R-squared & 0.61 \\
\hline F-Test & $8.32 * * *$ \\
\hline AIC & -613.72 \\
\hline BIC & -539.67 \\
\hline
\end{tabular}

Note: White heteroskedasticity-robust standard errors in brackets. ${ }^{*},{ }^{*}$ and ${ }^{* * *}$ show significance at the $10 \%-, 5 \%-$, and $1 \%$-level, respectively. None of the specification tests indicates misspecification. 


\section{OPAL UK Gasoline}

Table 17 Gasoline ARDL regression results weekly data (3 lags)

\begin{tabular}{|c|c|}
\hline \multicolumn{2}{|l|}{ Dep. Var.: $\triangle$ OPAL UK Gasoline } \\
\hline const & $\begin{array}{l}-0.00 \\
(0.00)\end{array}$ \\
\hline L1 $\triangle$ OPAL UK Gasoline & $\begin{array}{l}0.61 * * * \\
(0.14)\end{array}$ \\
\hline L2 $\triangle$ OPAL UK Gasoline & $\begin{array}{l}-0.17 \\
(0.15)\end{array}$ \\
\hline L3 $\triangle$ OPAL UK Gasoline & $\begin{array}{l}0.21^{*} \\
(0.12)\end{array}$ \\
\hline$\Delta$ EU Emission Allowance & $\begin{array}{l}-0.01 \\
(0.01)\end{array}$ \\
\hline L1 $\Delta$ EU Emission Allowance & $\begin{array}{l}0.03 * * * \\
(0.01)\end{array}$ \\
\hline L2 $\Delta$ EU Emission Allowance & $\begin{array}{l}-0.01 \\
(0.01)\end{array}$ \\
\hline L3 $\Delta$ EU Emission Allowance & $\begin{array}{l}-0.00 \\
(0.01)\end{array}$ \\
\hline$\Delta$ UK Interbank Overnight Middle Rate & $\begin{array}{l}0.07 \\
(0.04)\end{array}$ \\
\hline L1 $\Delta$ UK Interbank Overnight Middle Rate & $\begin{array}{l}0.03 \\
(0.05)\end{array}$ \\
\hline L2 $\Delta$ UK Interbank Overnight Middle Rate & $\begin{array}{l}0.03 \\
(0.04)\end{array}$ \\
\hline L3 $\Delta$ UK Interbank Overnight Middle Rate & $\begin{array}{l}0.06 \\
(0.06)\end{array}$ \\
\hline$\Delta$ US Dollar to British Pound Sterling exchange rate & $\begin{array}{l}0.15 \\
(0.14)\end{array}$ \\
\hline L1 $\Delta$ US Dollar to British Pound Sterling exchange rate & $\begin{array}{l}0.16 \\
(0.16)\end{array}$ \\
\hline L2 $\Delta$ US Dollar to British Pound Sterling exchange rate & $\begin{array}{l}-0.25 \\
(0.14)\end{array}$ \\
\hline L3 $\Delta$ US Dollar to British Pound Sterling exchange rate & $\begin{array}{l}-0.27 * * \\
(0.12)\end{array}$ \\
\hline$\Delta$ Brent Crude Oil UK Close & $\begin{array}{l}-0.08 * \\
(0.04)\end{array}$ \\
\hline L1 $\Delta$ Brent Crude Oil UK Close & $\begin{array}{l}0.10 * * * \\
(0.03)\end{array}$ \\
\hline L2 $\Delta$ Brent Crude Oil UK Close & $\begin{array}{l}0.12 * * * \\
(0.03)\end{array}$ \\
\hline L3 $\Delta$ Brent Crude Oil UK Close & $\begin{array}{l}0.11 * * * \\
(0.04)\end{array}$ \\
\hline$\Delta 1$ Month Forward Natural Gas & $\begin{array}{l}-0.00 \\
(0.02)\end{array}$ \\
\hline L1 $\Delta 1$ Month Forward Natural Gas & $\begin{array}{l}0.01 \\
(0.02)\end{array}$ \\
\hline L2 $\Delta 1$ Month Forward Natural Gas & $\begin{array}{l}-0.01 \\
(0.01)\end{array}$ \\
\hline L3 $\Delta 1$ Month Forward Natural Gas & $\begin{array}{l}-0.01 \\
(0.01) \\
\end{array}$ \\
\hline Obs. & 104 \\
\hline R-squared & 0.67 \\
\hline F-Test & $8.50 * * *$ \\
\hline AIC & -560.15 \\
\hline $\mathrm{BIC}$ & -496.68 \\
\hline
\end{tabular}

Note: White heteroskedasticity-robust standard errors in brackets. *, ** and *** show significance at the $10 \%-, 5 \%$-, and $1 \%$-level, respectively. None of the specification tests indicates misspecification. 
Table 18 Gasoline ARDL regression results weekly data (5 lags)

\begin{tabular}{|c|c|}
\hline \multicolumn{2}{|l|}{ Dep. Var.: $\triangle$ OPAL UK Gasoline } \\
\hline const & $\begin{array}{l}-0.00 \\
(0.00)\end{array}$ \\
\hline L1 $\triangle$ OPAL UK Gasoline & $\begin{array}{l}0.51 * * * \\
(0.18)\end{array}$ \\
\hline L2 $\triangle$ OPAL UK Gasoline & $\begin{array}{l}-0.25 \\
(0.17)\end{array}$ \\
\hline L3 $\triangle$ OPAL UK Gasoline & $\begin{array}{l}0.24 \\
(0.20)\end{array}$ \\
\hline L4 $\Delta$ OPAL UK Gasoline & $\begin{array}{l}-0.02 \\
(0.19)\end{array}$ \\
\hline L5 $\triangle$ OPAL UK Gasoline & $\begin{array}{l}-0.03 \\
(0.11)\end{array}$ \\
\hline$\Delta$ EU Emission Allowance & $\begin{array}{l}-0.02 \\
(0.02)\end{array}$ \\
\hline L1 $\Delta$ EU Emission Allowance & $\begin{array}{l}0.03^{*} \\
(0.02)\end{array}$ \\
\hline L2 $\Delta$ EU Emission Allowance & $\begin{array}{l}0.00 \\
(0.01)\end{array}$ \\
\hline L3 $\Delta$ EU Emission Allowance & $\begin{array}{l}-0.01 \\
(0.01)\end{array}$ \\
\hline L4 $\Delta$ EU Emission Allowance & $\begin{array}{l}0.01 \\
(0.01)\end{array}$ \\
\hline L5 $\Delta$ EU Emission Allowance & $\begin{array}{l}-0.00 \\
(0.01)\end{array}$ \\
\hline$\Delta$ UK Interbank Overnight Middle Rate & $\begin{array}{l}0.01 \\
(0.05)\end{array}$ \\
\hline L1 $\Delta$ UK Interbank Overnight Middle Rate & $\begin{array}{l}-0.02 \\
(0.07)\end{array}$ \\
\hline L2 $\Delta$ UK Interbank Overnight Middle Rate & $\begin{array}{l}-0.01 \\
(0.06)\end{array}$ \\
\hline L3 $\Delta$ UK Interbank Overnight Middle Rate & $\begin{array}{l}-0.00 \\
(0.09)\end{array}$ \\
\hline L4 $\Delta$ UK Interbank Overnight Middle Rate & $\begin{array}{l}-0.09 \\
(0.08)\end{array}$ \\
\hline L5 $\Delta$ UK Interbank Overnight Middle Rate & $\begin{array}{l}-0.08 \\
(0.06)\end{array}$ \\
\hline$\Delta$ US Dollar to British Pound Sterling exchange rate & $\begin{array}{l}0.06 \\
(0.16)\end{array}$ \\
\hline L1 $\Delta$ US Dollar to British Pound Sterling exchange rate & $\begin{array}{l}0.13 \\
(0.19)\end{array}$ \\
\hline L2 $\Delta$ US Dollar to British Pound Sterling exchange rate & $\begin{array}{l}-0.13 \\
(0.16)\end{array}$ \\
\hline L3 $\Delta$ US Dollar to British Pound Sterling exchange rate & $\begin{array}{l}-0.16 \\
(0.14)\end{array}$ \\
\hline L4 $\Delta$ US Dollar to British Pound Sterling exchange rate & $\begin{array}{l}-0.12 \\
(0.15)\end{array}$ \\
\hline L5 $\Delta$ US Dollar to British Pound Sterling exchange rate & $\begin{array}{l}0.09 \\
(0.18)\end{array}$ \\
\hline$\Delta$ Brent Crude Oil UK Close & $\begin{array}{l}0.01 \\
(0.06)\end{array}$ \\
\hline L1 $\Delta$ Brent Crude Oil UK Close & $\begin{array}{l}0.08 * * \\
(0.04)\end{array}$ \\
\hline L2 $\Delta$ Brent Crude Oil UK Close & $\begin{array}{l}0.12 * * * \\
(0.05)\end{array}$ \\
\hline L3 $\Delta$ Brent Crude Oil UK Close & $\begin{array}{l}0.13 * * * \\
(0.04)\end{array}$ \\
\hline L4 $\Delta$ Brent Crude Oil UK Close & $\begin{array}{l}0.07 \\
(0.05)\end{array}$ \\
\hline L5 $\Delta$ Brent Crude Oil UK Close & $\begin{array}{l}0.04 \\
(0.05)\end{array}$ \\
\hline$\Delta 1$ Month Forward Natural Gas & $\begin{array}{l}-0.01 \\
(0.02)\end{array}$ \\
\hline L1 $\Delta 1$ Month Forward Natural Gas & $\begin{array}{l}0.01 \\
(0.02)\end{array}$ \\
\hline L2 $\Delta 1$ Month Forward Natural Gas & $\begin{array}{l}-0.02 \\
(0.02)\end{array}$ \\
\hline L3 $\Delta 1$ Month Forward Natural Gas & $\begin{array}{l}-0.00 \\
(0.01)\end{array}$ \\
\hline L4 $\Delta 1$ Month Forward Natural Gas & -0.01 \\
\hline
\end{tabular}




\begin{tabular}{|l|l|} 
& $(0.02)$ \\
L5 $\Delta \mathbf{1}$ Month Forward Natural Gas & 0.01 \\
\hline Obs. & $(0.02)$ \\
R-squared & 102 \\
F-Test & 0.70 \\
AIC & $6.12^{* * *}$ \\
BIC & -536.01 \\
\hline
\end{tabular}

Note: White heteroskedasticity-robust standard errors in brackets. ${ }^{*},{ }^{*}$ and ${ }^{* * *}$ show significance at the $10 \%-, 5 \%-$, and $1 \%$-level, respectively. None of the specification tests indicates misspecification.

Table 19 Gasoline ARDL regression results weekly data, asymmetry EUA (1 lag)

\begin{tabular}{|c|c|}
\hline \multicolumn{2}{|l|}{ Dep. Var.: $\triangle$ OPAL UK Gasoline } \\
\hline const & $\begin{array}{l}-0.00 \\
(0.00)\end{array}$ \\
\hline L1 $\Delta$ OPAL UK Gasoline & $\begin{array}{l}0.65^{* * * *} \\
(0.10)\end{array}$ \\
\hline$\Delta$ EU Emission Allowance Positive & $\begin{array}{l}0.01 \\
(0.03)\end{array}$ \\
\hline L1 $\Delta$ EU Emission Allowance Positive & $\begin{array}{l}0.04 \\
(0.04)\end{array}$ \\
\hline$\Delta$ EU Emission Allowance Negative & $\begin{array}{l}0.01 \\
(0.01)\end{array}$ \\
\hline L1 $\Delta$ EU Emission Allowance Negative & $\begin{array}{l}0.02 * \\
(0.01)\end{array}$ \\
\hline$\Delta$ UK Interbank Overnight Middle Rate & $\begin{array}{l}0.01 \\
(0.04)\end{array}$ \\
\hline L1 $\Delta$ UK Interbank Overnight Middle Rate & $\begin{array}{l}-0.02 \\
(0.04)\end{array}$ \\
\hline$\Delta$ US Dollar to British Pound Sterling exchange rate & $\begin{array}{l}0.21 \\
(0.15)\end{array}$ \\
\hline L1 $\Delta$ US Dollar to British Pound Sterling exchange rate & $\begin{array}{l}0.27^{*} \\
(0.20)\end{array}$ \\
\hline$\Delta$ Brent Crude Oil UK Close & $\begin{array}{l}-0.09 * \\
(0.05)\end{array}$ \\
\hline L1 $\Delta$ Brent Crude Oil UK Close & $\begin{array}{l}0.08 * * \\
(0.04)\end{array}$ \\
\hline$\Delta 1$ Month Forward Natural Gas & $\begin{array}{l}0.01 \\
(0.02)\end{array}$ \\
\hline L1 $\Delta 1$ Month Forward Natural Gas & $\begin{array}{l}0.01 \\
(0.02)\end{array}$ \\
\hline Obs. & 106 \\
\hline R-squared & 0.52 \\
\hline F-Test & $8.66 * * *$ \\
\hline $\mathrm{AIC}$ & -547.01 \\
\hline $\mathrm{BIC}$ & -509.72 \\
\hline
\end{tabular}

Note: White heteroskedasticity-robust standard errors in brackets. ${ }^{*},{ }^{*}$ and ${ }^{* * *}$ show significance at the $10 \%-, 5 \%-$ and $1 \%$-level, respectively. None of the specification tests indicates misspecification. 
Table 20 Gasoline ARDL regression results weekly data, asymmetry EUA (3 lags)

\begin{tabular}{|c|c|}
\hline \multicolumn{2}{|l|}{ Dep. Var.: $\triangle$ OPAL UK Gasoline } \\
\hline const & $\begin{array}{l}-0.00 \\
(0.00)\end{array}$ \\
\hline L1 $\Delta$ OPAL UK Gasoline & $\begin{array}{l}0.61 * * * \\
(0.14)\end{array}$ \\
\hline L2 $\Delta$ OPAL UK Gasoline & $\begin{array}{l}-0.16 \\
(0.15)\end{array}$ \\
\hline L3 $\triangle$ OPAL UK Gasoline & $\begin{array}{l}0.19 \\
(0.12)\end{array}$ \\
\hline$\Delta$ EU Emission Allowance Positive & $\begin{array}{l}-0.04 \\
(0.03)\end{array}$ \\
\hline L1 $\Delta$ EU Emission Allowance Positive & $\begin{array}{l}0.02 \\
(0.03)\end{array}$ \\
\hline L2 $\Delta$ EU Emission Allowance Positive & $\begin{array}{l}0.00 \\
(0.03)\end{array}$ \\
\hline L3 $\Delta$ EU Emission Allowance Positive & $\begin{array}{l}0.05^{*} \\
(0.03)\end{array}$ \\
\hline$\Delta$ EU Emission Allowance Negative & $\begin{array}{l}0.00 \\
(0.01)\end{array}$ \\
\hline L1 $\Delta$ EU Emission Allowance Negative & $\begin{array}{l}0.02 * \\
(0.01)\end{array}$ \\
\hline L2 $\Delta$ EU Emission Allowance Negative & $\begin{array}{l}-0.01 \\
(0.02)\end{array}$ \\
\hline L3 $\Delta$ EU Emission Allowance Negative & $\begin{array}{l}-0.03 \\
(0.02)\end{array}$ \\
\hline$\Delta$ UK Interbank Overnight Middle Rate & $\begin{array}{l}0.07^{*} \\
(0.04)\end{array}$ \\
\hline L1 $\Delta$ UK Interbank Overnight Middle Rate & $\begin{array}{l}0.04 \\
(0.05)\end{array}$ \\
\hline L2 $\Delta$ UK Interbank Overnight Middle Rate & $\begin{array}{l}0.03 \\
(0.04)\end{array}$ \\
\hline L3 $\Delta$ UK Interbank Overnight Middle Rate & $\begin{array}{l}0.06 \\
(0.06)\end{array}$ \\
\hline$\Delta$ US Dollar to British Pound Sterling exchange rate & $\begin{array}{l}0.16 \\
(0.14)\end{array}$ \\
\hline L1 $\Delta$ US Dollar to British Pound Sterling exchange rate & $\begin{array}{l}0.16 \\
(0.16)\end{array}$ \\
\hline L2 $\Delta$ US Dollar to British Pound Sterling exchange rate & $\begin{array}{l}-0.27 * \\
(0.15)\end{array}$ \\
\hline L3 $\Delta$ US Dollar to British Pound Sterling exchange rate & $\begin{array}{l}-0.30^{* * *} \\
(0.11)\end{array}$ \\
\hline$\Delta$ Brent Crude Oil UK Close & $\begin{array}{l}-0.07 \\
(0.04)\end{array}$ \\
\hline L1 $\Delta$ Brent Crude Oil UK Close & $\begin{array}{l}0.10 * * * \\
(0.04)\end{array}$ \\
\hline L2 $\Delta$ Brent Crude Oil UK Close & $\begin{array}{l}0.14 * * * \\
(0.04)\end{array}$ \\
\hline L3 $\Delta$ Brent Crude Oil UK Close & $\begin{array}{l}0.10^{* * * *} \\
(0.04)\end{array}$ \\
\hline$\Delta 1$ Month Forward Natural Gas & $\begin{array}{l}-0.00 \\
(0.02)\end{array}$ \\
\hline L1 $\Delta 1$ Month Forward Natural Gas & $\begin{array}{l}0.02 \\
(0.02)\end{array}$ \\
\hline L2 $\Delta 1$ Month Forward Natural Gas & $\begin{array}{l}-0.02 \\
(0.01)\end{array}$ \\
\hline L3 $\Delta 1$ Month Forward Natural Gas & $\begin{array}{l}-0.02 \\
(0.01)\end{array}$ \\
\hline Obs. & 104 \\
\hline R-squared & 0.69 \\
\hline F-Test & $8.75 * * *$ \\
\hline AIC & -557.30 \\
\hline $\mathrm{BIC}$ & -483.26 \\
\hline
\end{tabular}

Note: White heteroskedasticity-robust standard errors in brackets. ${ }^{*},{ }^{*}$ and ${ }^{* * *}$ show significance at the $10 \%-, 5 \%-$, and $1 \%$-level, respectively. None of the specification tests indicates misspecification. 


\section{Low density polyethylene film}

Table 21 LDPE ARDL regression results monthly data (3 lags)

\begin{tabular}{|c|c|}
\hline \multicolumn{2}{|l|}{ Dep. Var.: $\triangle \mathrm{LDPE}$} \\
\hline const & $\begin{array}{l}-0.00 \\
(0.01)\end{array}$ \\
\hline L1 $\Delta$ LDPE & $\begin{array}{l}0.32 * * \\
(0.15)\end{array}$ \\
\hline L2 $\Delta$ LDPE & $\begin{array}{l}0.03 \\
(0.14)\end{array}$ \\
\hline L3 $\Delta$ LDPE & $\begin{array}{l}-0.23 * * * \\
(0.09)\end{array}$ \\
\hline$\triangle$ APX Power UK Spot Base Load Index & $\begin{array}{l}-0.03 \\
(0.02)\end{array}$ \\
\hline L1 $\Delta$ APX Power UK Spot Base Load Index & $\begin{array}{l}0.02 \\
(0.03)\end{array}$ \\
\hline L2 $\triangle$ APX Power UK Spot Base Load Index & $\begin{array}{l}0.01 \\
(0.02)\end{array}$ \\
\hline L3 $\Delta$ APX Power UK Spot Base Load Index & $\begin{array}{l}0.01 \\
(0.02)\end{array}$ \\
\hline$\Delta$ Euro Overnight Index Average Offered Rate & $\begin{array}{l}-0.14 \\
(0.11)\end{array}$ \\
\hline L1 $\Delta$ Euro Overnight Index Average Offered Rate & $\begin{array}{l}-0.05 \\
(0.08)\end{array}$ \\
\hline L2 $\Delta$ Euro Overnight Index Average Offered Rate & $\begin{array}{l}0.04 \\
(0.09)\end{array}$ \\
\hline L3 $\Delta$ Euro Overnight Index Average Offered Rate & $\begin{array}{l}0.07 \\
(0.08)\end{array}$ \\
\hline$\Delta$ Euro to US Dollar exchange rate & $\begin{array}{l}0.44 \\
(0.30)\end{array}$ \\
\hline L1 $\Delta$ Euro to US Dollar exchange rate & $\begin{array}{l}0.16 \\
(0.38)\end{array}$ \\
\hline L2 $\Delta$ Euro to US Dollar exchange rate & $\begin{array}{l}-0.06 \\
(0.28)\end{array}$ \\
\hline L3 $\Delta$ Euro to US Dollar exchange rate & $\begin{array}{l}-0.18 \\
(0.35)\end{array}$ \\
\hline$\Delta$ Naphtha & $\begin{array}{l}0.16^{* * *} \\
(0.07)\end{array}$ \\
\hline L1 $\Delta$ Naphtha & $\begin{array}{l}0.19 * * * \\
(0.05)\end{array}$ \\
\hline L2 $\Delta$ Naphtha & $\begin{array}{l}0.07 \\
(0.07)\end{array}$ \\
\hline L3 $\Delta$ Naphtha & $\begin{array}{l}0.09 \\
(0.07)\end{array}$ \\
\hline$\Delta$ West European gas & $\begin{array}{l}0.06 \\
(0.17)\end{array}$ \\
\hline L1 $\Delta$ West European gas & $\begin{array}{l}-0.01 \\
(0.13)\end{array}$ \\
\hline L2 $\Delta$ West European gas & $\begin{array}{l}-0.16 \\
(0.16)\end{array}$ \\
\hline L3 $\Delta$ West European gas & $\begin{array}{l}0.20 \\
(0.17)\end{array}$ \\
\hline Obs. & 71 \\
\hline R-squared & 0.63 \\
\hline F-Test & $8.42 * * *$ \\
\hline AIC & -244.87 \\
\hline $\mathrm{BIC}$ & -189.90 \\
\hline
\end{tabular}

Note: White heteroskedasticity-robust standard errors in brackets. *, ** and *** show significance at the 10\%-, 5\%-, and 1\%-level, respectively. None of the specification tests indicates misspecification. 
Table 22 LDPE ARDL regression results monthly data (5 lags)

\begin{tabular}{|c|c|}
\hline \multicolumn{2}{|l|}{ Dep. Var.: $\triangle \mathrm{LDPE}$} \\
\hline const & $\begin{array}{l}0.00 \\
(0.01)\end{array}$ \\
\hline L1 $\Delta$ LDPE & $\begin{array}{l}0.35 * * \\
(0.16)\end{array}$ \\
\hline L2 $\Delta$ LDPE & $\begin{array}{l}-0.11 \\
(0.19)\end{array}$ \\
\hline L3 $\Delta$ LDPE & $\begin{array}{l}-0.30^{*} \\
(0.16)\end{array}$ \\
\hline L4 $\Delta$ LDPE & $\begin{array}{l}-0.22 \\
(0.18)\end{array}$ \\
\hline L5 $\Delta$ LDPE & $\begin{array}{l}0.03 \\
(0.15)\end{array}$ \\
\hline$\triangle$ APX Power UK Spot Base Load Index & $\begin{array}{l}0.00 \\
(0.02)\end{array}$ \\
\hline L1 $\Delta$ APX Power UK Spot Base Load Index & $\begin{array}{l}0.03 \\
(0.03)\end{array}$ \\
\hline L2 $\triangle$ APX Power UK Spot Base Load Index & $\begin{array}{l}0.02 \\
(0.02)\end{array}$ \\
\hline L3 $\triangle$ APX Power UK Spot Base Load Index & $\begin{array}{l}0.02 \\
(0.03)\end{array}$ \\
\hline L4 $\triangle$ APX Power UK Spot Base Load Index & $\begin{array}{l}-0.02 \\
(0.03)\end{array}$ \\
\hline L5 $\Delta$ APX Power UK Spot Base Load Index & $\begin{array}{l}-0.05 \\
(0.03)\end{array}$ \\
\hline$\Delta$ Euro Overnight Index Average Offered Rate & $\begin{array}{l}-0.10 \\
(0.12)\end{array}$ \\
\hline L1 $\Delta$ Euro Overnight Index Average Offered Rate & $\begin{array}{l}-0.11 \\
(0.12)\end{array}$ \\
\hline L2 $\Delta$ Euro Overnight Index Average Offered Rate & $\begin{array}{l}-0.01 \\
(0.11)\end{array}$ \\
\hline L3 $\Delta$ Euro Overnight Index Average Offered Rate & $\begin{array}{l}0.08 \\
(0.11)\end{array}$ \\
\hline L4 $\Delta$ Euro Overnight Index Average Offered Rate & $\begin{array}{l}0.07 \\
(0.16)\end{array}$ \\
\hline L5 $\Delta$ Euro Overnight Index Average Offered Rate & $\begin{array}{l}0.05 \\
(0.12)\end{array}$ \\
\hline$\Delta$ Euro to US Dollar exchange rate & $\begin{array}{l}0.54 \\
(0.44)\end{array}$ \\
\hline L1 $\Delta$ Euro to US Dollar exchange rate & $\begin{array}{l}0.05 \\
(0.33)\end{array}$ \\
\hline L2 $\Delta$ Euro to US Dollar exchange rate & $\begin{array}{l}-0.26 \\
(0.35)\end{array}$ \\
\hline L3 $\Delta$ Euro to US Dollar exchange rate & $\begin{array}{l}0.12 \\
(0.43)\end{array}$ \\
\hline L4 $\Delta$ Euro to US Dollar exchange rate & $\begin{array}{l}-0.12 \\
(0.47)\end{array}$ \\
\hline L5 $\Delta$ Euro to US Dollar exchange rate & $\begin{array}{l}-0.37 \\
(0.33)\end{array}$ \\
\hline$\Delta$ Naphtha & $\begin{array}{l}0.10 \\
(0.08)\end{array}$ \\
\hline L1 $\Delta$ Naphtha & $\begin{array}{l}0.19 * * * \\
(0.06)\end{array}$ \\
\hline L2 $\Delta$ Naphtha & $\begin{array}{l}0.11 \\
(0.09)\end{array}$ \\
\hline L3 $\Delta$ Naphtha & $\begin{array}{l}0.11 \\
(0.09)\end{array}$ \\
\hline L4 $\Delta$ Naphtha & $\begin{array}{l}0.09 \\
(0.10)\end{array}$ \\
\hline L5 $\Delta$ Naphtha & $\begin{array}{l}0.18 * * \\
(0.09)\end{array}$ \\
\hline$\Delta$ West European gas & $\begin{array}{l}-0.10 \\
(0.22)\end{array}$ \\
\hline L1 $\Delta$ West European gas & $\begin{array}{l}0.03 \\
(0.15)\end{array}$ \\
\hline L2 $\Delta$ West European gas & $\begin{array}{l}-0.30^{*} \\
(0.17)\end{array}$ \\
\hline L3 $\Delta$ West European gas & $\begin{array}{l}0.46^{* *} \\
(0.20)\end{array}$ \\
\hline L4 $\Delta$ West European gas & -0.21 \\
\hline
\end{tabular}




\begin{tabular}{|l|l|} 
& $(0.15)$ \\
L5 $\boldsymbol{\Delta}$ West European gas & -0.16 \\
\hline Obs. & $(0.23)$ \\
R-squared & 71 \\
F-Test & 0.73 \\
AIC & $14.07 * * *$ \\
BIC & -235.72 \\
\hline
\end{tabular}

Note: White heteroskedasticity-robust standard errors in brackets. ${ }^{*}, * *$ and $* * *$ show significance at the $10 \%-, 5 \%$-, and $1 \%$-level, respectively. None of the specification tests indicates misspecification.

Table 23 LDPE ARDL regression results monthly data, asymmetry gas (1 lag)

\begin{tabular}{|l|l|}
\hline Dep. Var.: $\Delta$ LDPE & 0.00 \\
const & $(0.01)$ \\
& $0.41^{* * *}$ \\
$\Delta$ APX Power UK Spot Base Load Index & $(0.10)$ \\
L1 $\Delta$ APX Power UK Spot Base Load Index & -0.03 \\
& $(0.02)$ \\
$\Delta$ Euro Overnight Index Average Offered Rate & 0.00 \\
L1 $\Delta$ Euro Overnight Index Average Offered Rate & $0.02)$ \\
& -0.06 \\
$\Delta$ Euro to US Dollar exchange rate & $(0.09)$ \\
L1 $\Delta$ Euro to US Dollar exchange rate & -0.06 \\
$\Delta$ Naphtha Positive & $(0.08)$ \\
L1 $\Delta$ Naphtha Positive & 0.39 \\
$\Delta$ Naphtha Negative & $(0.26)$ \\
L1 $\Delta$ Naphtha Negative & -0.05 \\
$\Delta$ West European gas & $0.25)$ \\
L1 $\Delta$ West European gas & $0.22 *$ \\
& $(0.11)$ \\
\hline Obs. & 0.07 \\
R-squared & $(0.14)$ \\
AIC & 0.07 \\
BIC & $(0.10)$ \\
Nest & $0.30 * * *$ \\
& $(0.10)$ \\
& 0.10 \\
& $(0.15)$ \\
& -0.06 \\
& $(0.12)$ \\
\hline & 75 \\
& 0.50 \\
& $5.95 * * *$ \\
& -252.82 \\
& -220.37 \\
\hline
\end{tabular}

Note: White heteroskedasticity-robust standard errors in brackets. *, ** and *** show significance at the 10\%-, 5\%-, and 1\%-level, respectively. None of the specification tests indicates misspecification. 
Table 24 LDPE ARDL regression results monthly data, asymmetry gas (3 lags)

\begin{tabular}{|c|c|}
\hline \multicolumn{2}{|l|}{ Dep. Var.: $\triangle L D P E$} \\
\hline const & $\begin{array}{l}0.01 \\
(0.03)\end{array}$ \\
\hline L1 $\Delta$ LDPE & $\begin{array}{l}0.36 * * \\
(0.16)\end{array}$ \\
\hline L2 $\Delta$ LDPE & $\begin{array}{l}-0.01 \\
(0.15)\end{array}$ \\
\hline L3 $\Delta$ LDPE & $\begin{array}{l}-0.20 * * \\
(0.08)\end{array}$ \\
\hline$\triangle$ APX Power UK Spot Base Load Index & $\begin{array}{l}-0.02 \\
(0.03)\end{array}$ \\
\hline L1 $\triangle$ APX Power UK Spot Base Load Index & $\begin{array}{l}0.02 \\
(0.03)\end{array}$ \\
\hline L2 $\triangle$ APX Power UK Spot Base Load Index & $\begin{array}{l}0.00 \\
(0.03)\end{array}$ \\
\hline L3 $\triangle$ APX Power UK Spot Base Load Index & $\begin{array}{l}0.02 \\
(0.02)\end{array}$ \\
\hline$\Delta$ Euro Overnight Index Average Offered Rate & $\begin{array}{l}-0.17 \\
(0.12)\end{array}$ \\
\hline L1 $\Delta$ Euro Overnight Index Average Offered Rate & $\begin{array}{l}-0.12 \\
(0.10)\end{array}$ \\
\hline L2 $\Delta$ Euro Overnight Index Average Offered Rate & $\begin{array}{l}0.01 \\
(0.09)\end{array}$ \\
\hline L3 $\Delta$ Euro Overnight Index Average Offered Rate & $\begin{array}{l}0.09 \\
(0.09)\end{array}$ \\
\hline$\Delta$ Euro to US Dollar exchange rate & $\begin{array}{l}0.36 \\
(0.35)\end{array}$ \\
\hline L1 $\Delta$ Euro to US Dollar exchange rate & $\begin{array}{l}0.16 \\
(0.38)\end{array}$ \\
\hline L2 $\Delta$ Euro to US Dollar exchange rate & $\begin{array}{l}-0.06 \\
(0.29)\end{array}$ \\
\hline L3 $\Delta$ Euro to US Dollar exchange rate & $\begin{array}{l}-0.27 \\
(0.36)\end{array}$ \\
\hline$\Delta$ Naphtha Positive & $\begin{array}{l}0.25 * * \\
(0.12)\end{array}$ \\
\hline L1 $\Delta$ Naphtha Positive & $\begin{array}{l}0.05 \\
(0.16)\end{array}$ \\
\hline L2 $\Delta$ Naphtha gas Positive & $\begin{array}{l}-0.06 \\
(0.19)\end{array}$ \\
\hline L3 $\Delta$ Naphtha gas Positive & $\begin{array}{l}0.06 \\
(0.21)\end{array}$ \\
\hline$\Delta$ Naphtha gas Negative & $\begin{array}{l}0.07 \\
(0.12)\end{array}$ \\
\hline L1 $\Delta$ Naphtha gas Negative & $\begin{array}{l}0.29 * * * \\
(0.09)\end{array}$ \\
\hline L2 $\Delta$ Naphtha gas Negative & $\begin{array}{l}0.14 \\
(0.11)\end{array}$ \\
\hline L3 $\Delta$ Naphtha gas Negative & $\begin{array}{l}0.11 \\
(0.14)\end{array}$ \\
\hline$\Delta$ West European gas & $\begin{array}{l}0.04 \\
(0.18)\end{array}$ \\
\hline L1 $\Delta$ West European gas & $\begin{array}{l}-0.03 \\
(0.13)\end{array}$ \\
\hline L2 $\Delta$ West European gas & $\begin{array}{l}-0.19 \\
(0.16)\end{array}$ \\
\hline L3 $\Delta$ West European gas & $\begin{array}{l}0.19 \\
(0.18)\end{array}$ \\
\hline Obs. & 73 \\
\hline R-squared & 0.64 \\
\hline F-Test & $7.69 * * *$ \\
\hline AIC & -240.89 \\
\hline $\mathrm{BIC}$ & -176.76 \\
\hline
\end{tabular}

Note: White heteroskedasticity-robust standard errors in brackets. ${ }^{*},{ }^{*}$ and $*^{* *}$ show significance at the $10 \%-, 5 \%-$ and $1 \%$-level, respectively. None of the specification tests indicates misspecification. 
Ammonium nitrate

Table 25 Ammonium nitrate ARDL regression results monthly data (3 lags)

\begin{tabular}{|c|c|}
\hline \multicolumn{2}{|l|}{ Dep. Var.: $\triangle$ Ammonium Nitrate } \\
\hline const & $\begin{array}{l}-0.00 \\
(0.01)\end{array}$ \\
\hline L1 $\Delta$ Ammonium Nitrate & $\begin{array}{l}0.23 \\
(0.15)\end{array}$ \\
\hline L2 $\Delta$ Ammonium Nitrate & $\begin{array}{l}-0.06 \\
(0.09)\end{array}$ \\
\hline L3 $\Delta$ Ammonium Nitrate & $\begin{array}{l}-0.24 * * \\
(0.10)\end{array}$ \\
\hline$\triangle$ APX Power UK Spot Base Load Index & $\begin{array}{l}0.04 \\
(0.03)\end{array}$ \\
\hline L1 $\triangle$ APX Power UK Spot Base Load Index & $\begin{array}{l}0.07 * * \\
(0.03)\end{array}$ \\
\hline L2 $\triangle$ APX Power UK Spot Base Load Index & $\begin{array}{l}0.04 * \\
(0.03)\end{array}$ \\
\hline L3 $\Delta$ APX Power UK Spot Base Load Index & $\begin{array}{l}0.01 \\
(0.02)\end{array}$ \\
\hline$\Delta$ Euro Overnight Index Average Offered Rate & $\begin{array}{l}-0.02 \\
(0.07)\end{array}$ \\
\hline L1 $\Delta$ Euro Overnight Index Average Offered Rate & $\begin{array}{l}-0.01 \\
(0.07)\end{array}$ \\
\hline L2 $\Delta$ Euro Overnight Index Average Offered Rate & $\begin{array}{l}0.00 \\
(0.12)\end{array}$ \\
\hline L3 $\Delta$ Euro Overnight Index Average Offered Rate & $\begin{array}{l}-0.04 \\
(0.01)\end{array}$ \\
\hline$\Delta$ Euro to US Dollar exchange rate & $\begin{array}{l}0.04 \\
(0.28)\end{array}$ \\
\hline L1 $\Delta$ Euro to US Dollar exchange rate & $\begin{array}{l}0.04 \\
(0.40)\end{array}$ \\
\hline L2 $\Delta$ Euro to US Dollar exchange rate & $\begin{array}{l}0.39 \\
(0.31)\end{array}$ \\
\hline L3 $\Delta$ Euro to US Dollar exchange rate & $\begin{array}{l}0.14 \\
(0.30)\end{array}$ \\
\hline$\Delta$ Brent Crude Oil UK Close & $\begin{array}{l}-0.04 \\
(0.07)\end{array}$ \\
\hline L1 $\Delta$ Brent Crude Oil UK Close & $\begin{array}{l}0.00 \\
(0.07)\end{array}$ \\
\hline L2 $\Delta$ Brent Crude Oil UK Close & $\begin{array}{l}-0.01 \\
(0.08)\end{array}$ \\
\hline L3 $\Delta$ Brent Crude Oil UK Close & $\begin{array}{l}-0.03 \\
(0.07)\end{array}$ \\
\hline$\Delta$ West European gas & $\begin{array}{l}0.05 \\
(0.11)\end{array}$ \\
\hline L1 $\Delta$ West European gas & $\begin{array}{l}0.05 \\
(0.11)\end{array}$ \\
\hline L2 $\Delta$ West European gas & $\begin{array}{l}0.29 \\
(0.21)\end{array}$ \\
\hline L3 $\Delta$ West European gas & $\begin{array}{l}-0.06 \\
(0.13)\end{array}$ \\
\hline Obs. & 76 \\
\hline R-squared & 0.29 \\
\hline F-Test & $1.64 *$ \\
\hline AIC & -244.53 \\
\hline $\mathrm{BIC}$ & -188.59 \\
\hline
\end{tabular}

Note: White heteroskedasticity-robust standard errors in brackets. *, ** and *** show significance at the $10 \%-, 5 \%$, and $1 \%$-level, respectively. None of the specification tests indicates misspecification. 
Table 26 Ammonium nitrate ARDL regression results monthly data (5 lags)

\begin{tabular}{|c|c|}
\hline \multicolumn{2}{|l|}{ Dep. Var.: A Ammonium Nitrate } \\
\hline const & $\begin{array}{l}0.00 \\
(0.01)\end{array}$ \\
\hline L1 $\Delta$ Ammonium Nitrate & $\begin{array}{l}0.23 \\
(0.13)\end{array}$ \\
\hline L2 $\Delta$ Ammonium Nitrate & $\begin{array}{l}-0.08 \\
(0.11)\end{array}$ \\
\hline L3 $\Delta$ Ammonium Nitrate & $\begin{array}{l}-0.25^{*} \\
(0.14)\end{array}$ \\
\hline L4 $\Delta$ Ammonium Nitrate & $\begin{array}{l}-0.27 * * \\
(0.11)\end{array}$ \\
\hline L5 $\Delta$ Ammonium Nitrate & $\begin{array}{l}-0.23 \\
(0.15)\end{array}$ \\
\hline$\triangle$ APX Power UK Spot Base Load Index & $\begin{array}{l}0.03 \\
(0.02)\end{array}$ \\
\hline L1 $\triangle$ APX Power UK Spot Base Load Index & $\begin{array}{l}0.07 * * \\
(0.03)\end{array}$ \\
\hline L2 $\triangle$ APX Power UK Spot Base Load Index & $\begin{array}{l}0.07 * * \\
(0.03)\end{array}$ \\
\hline L3 $\triangle$ APX Power UK Spot Base Load Index & $\begin{array}{l}0.05 * \\
(0.03)\end{array}$ \\
\hline L4 $\Delta$ APX Power UK Spot Base Load Index & $\begin{array}{l}0.07 * * \\
(0.03)\end{array}$ \\
\hline L5 $\Delta$ APX Power UK Spot Base Load Index & $\begin{array}{l}0.04 \\
(0.03)\end{array}$ \\
\hline$\Delta$ Euro Overnight Index Average Offered Rate & $\begin{array}{l}-0.03 \\
(0.07)\end{array}$ \\
\hline L1 $\Delta$ Euro Overnight Index Average Offered Rate & $\begin{array}{l}-0.06 \\
(0.11)\end{array}$ \\
\hline L2 $\Delta$ Euro Overnight Index Average Offered Rate & $\begin{array}{l}-0.02 \\
(0.13)\end{array}$ \\
\hline L3 $\Delta$ Euro Overnight Index Average Offered Rate & $\begin{array}{l}0.10 \\
(0.10)\end{array}$ \\
\hline L4 $\Delta$ Euro Overnight Index Average Offered Rate & $\begin{array}{l}0.29 * * \\
(0.12)\end{array}$ \\
\hline L5 $\Delta$ Euro Overnight Index Average Offered Rate & $\begin{array}{l}-0.15 \\
(0.12)\end{array}$ \\
\hline$\Delta$ Euro to US Dollar exchange rate & $\begin{array}{l}0.15 \\
(0.35)\end{array}$ \\
\hline L1 $\Delta$ Euro to US Dollar exchange rate & $\begin{array}{l}0.08 \\
(0.35)\end{array}$ \\
\hline L2 $\Delta$ Euro to US Dollar exchange rate & $\begin{array}{l}0.37 \\
(0.36)\end{array}$ \\
\hline L3 $\Delta$ Euro to US Dollar exchange rate & $\begin{array}{l}-0.04 \\
(0.30)\end{array}$ \\
\hline L4 $\Delta$ Euro to US Dollar exchange rate & $\begin{array}{l}-0.22 \\
(0.38)\end{array}$ \\
\hline L5 $\Delta$ Euro to US Dollar exchange rate & $\begin{array}{l}-0.12 \\
(0.32)\end{array}$ \\
\hline$\Delta$ Brent Crude Oil UK Close & $\begin{array}{l}-0.02 \\
(0.07)\end{array}$ \\
\hline L1 $\Delta$ Brent Crude Oil UK Close & $\begin{array}{l}-0.06 \\
(0.07)\end{array}$ \\
\hline L2 $\Delta$ Brent Crude Oil UK Close & $\begin{array}{l}-0.04 \\
(0.06)\end{array}$ \\
\hline L3 $\Delta$ Brent Crude Oil UK Close & $\begin{array}{l}-0.11 \\
(0.07)\end{array}$ \\
\hline L4 $\Delta$ Brent Crude Oil UK Close & $\begin{array}{l}-0.03 \\
(0.06)\end{array}$ \\
\hline L5 $\Delta$ Brent Crude Oil UK Close & $\begin{array}{l}-0.01 \\
(0.06)\end{array}$ \\
\hline$\Delta$ West European gas & $\begin{array}{l}-0.09 \\
(0.14)\end{array}$ \\
\hline L1 $\Delta$ West European gas & $\begin{array}{l}-0.04 \\
(0.18)\end{array}$ \\
\hline L2 $\Delta$ West European gas & $\begin{array}{l}0.36^{* *} \\
(0.17)\end{array}$ \\
\hline L3 $\Delta$ West European gas & $\begin{array}{l}0.01 \\
(0.11)\end{array}$ \\
\hline L4 $\Delta$ West European gas & 0.13 \\
\hline
\end{tabular}




\begin{tabular}{|l|l|} 
& $(0.12)$ \\
L5 $\boldsymbol{\Delta}$ West European gas & 0.00 \\
\hline Obs. & $(0.23)$ \\
R-squared & 71 \\
F-Test & 0.67 \\
AIC & $3.07 * * *$ \\
BIC & -268.43 \\
\hline
\end{tabular}

Note: White heteroskedasticity-robust standard errors in brackets. ${ }^{*},{ }^{*}$ and ${ }^{* * *}$ show significance at the $10 \%-, 5 \%-$, and $1 \%$-level, respectively. None of the specification tests indicates misspecification.

Table 27 Ammonium nitrate ARDL regression results monthly data, asymmetry gas (1 lag)

\begin{tabular}{|c|c|}
\hline \multicolumn{2}{|l|}{ Dep. Var.: $\triangle$ Ammonium Nitrate } \\
\hline const & $\begin{array}{l}-0.01 \\
(0.01)\end{array}$ \\
\hline L1 $\Delta$ Ammonium Nitrate & $\begin{array}{l}0.25^{*} \\
(0.14)\end{array}$ \\
\hline$\triangle$ APX Power UK Spot Base Load Index & $\begin{array}{l}0.04 * * \\
(0.02)\end{array}$ \\
\hline L1 $\Delta$ APX Power UK Spot Base Load Index & $\begin{array}{l}0.04 * * \\
(0.02)\end{array}$ \\
\hline$\Delta$ Euro Overnight Index Average Offered Rate & $\begin{array}{l}0.02 \\
(0.07)\end{array}$ \\
\hline L1 $\Delta$ Euro Overnight Index Average Offered Rate & $\begin{array}{l}-0.08 \\
(0.06)\end{array}$ \\
\hline$\Delta$ Euro to US Dollar exchange rate & $\begin{array}{l}-0.02 \\
(0.33)\end{array}$ \\
\hline L1 $\Delta$ Euro to US Dollar exchange rate & $\begin{array}{l}0.23 \\
(0.28)\end{array}$ \\
\hline$\Delta$ West European gas Positive & $\begin{array}{l}0.19^{*} \\
(0.11)\end{array}$ \\
\hline L1 $\Delta$ West European gas Positive & $\begin{array}{l}0.30^{*} \\
(0.18)\end{array}$ \\
\hline$\Delta$ West European gas Negative & $\begin{array}{l}-0.39 * \\
(0.22)\end{array}$ \\
\hline L1 $\Delta$ West European gas Negative & $\begin{array}{l}-0.31^{*} \\
(0.18)\end{array}$ \\
\hline$\Delta$ Brent Crude Oil UK Close & $\begin{array}{l}-0.04 \\
(0.07)\end{array}$ \\
\hline L1 $\Delta$ Brent Crude Oil UK Close & $\begin{array}{l}0.00 \\
(0.08)\end{array}$ \\
\hline Obs. & 75 \\
\hline R-squared & 0.19 \\
\hline F-Test & $1.81 *$ \\
\hline AIC & -246.87 \\
\hline $\mathrm{BIC}$ & -213.87 \\
\hline
\end{tabular}

Note: White heteroskedasticity-robust standard errors in brackets. ${ }^{*},{ }^{*}$ and ${ }^{* * *}$ show significance at the $10 \%-, 5 \%-$ and $1 \%$-level, respectively. None of the specification tests indicates misspecification. 
Table 28 Ammonium nitrate ARDL regression results monthly data, asymmetry gas (3 lags)

\begin{tabular}{|c|c|}
\hline \multicolumn{2}{|l|}{ Dep. Var.: A Ammonium Nitrate } \\
\hline const & $\begin{array}{l}-0.01 \\
(0.01)\end{array}$ \\
\hline L1 $\Delta$ Ammonium Nitrate & $\begin{array}{l}0.26 \\
(0.16)\end{array}$ \\
\hline L2 $\Delta$ Ammonium Nitrate & $\begin{array}{l}0.02 \\
(0.11)\end{array}$ \\
\hline L3 $\Delta$ Ammonium Nitrate & $\begin{array}{l}-0.42 * * * \\
(0.15)\end{array}$ \\
\hline$\triangle$ APX Power UK Spot Base Load Index & $\begin{array}{l}0.05 * * \\
(0.02)\end{array}$ \\
\hline L1 $\triangle$ APX Power UK Spot Base Load Index & $\begin{array}{l}0.07 * * \\
(0.03)\end{array}$ \\
\hline L2 $\triangle$ APX Power UK Spot Base Load Index & $\begin{array}{l}0.05 * * \\
(0.02)\end{array}$ \\
\hline L3 $\triangle$ APX Power UK Spot Base Load Index & $\begin{array}{l}0.02 \\
(0.02)\end{array}$ \\
\hline$\Delta$ Euro Overnight Index Average Offered Rate & $\begin{array}{l}-0.05 \\
(0.08)\end{array}$ \\
\hline L1 $\Delta$ Euro Overnight Index Average Offered Rate & $\begin{array}{l}-0.07 \\
(0.09)\end{array}$ \\
\hline L2 $\Delta$ Euro Overnight Index Average Offered Rate & $\begin{array}{l}0.10 \\
(0.13)\end{array}$ \\
\hline L3 $\Delta$ Euro Overnight Index Average Offered Rate & $\begin{array}{l}0.00 \\
(0.08)\end{array}$ \\
\hline$\Delta$ Euro to US Dollar exchange rate & $\begin{array}{l}0.03 \\
(0.32)\end{array}$ \\
\hline L1 $\Delta$ Euro to US Dollar exchange rate & $\begin{array}{l}0.20 \\
(0.38)\end{array}$ \\
\hline L2 $\Delta$ Euro to US Dollar exchange rate & $\begin{array}{l}0.23 \\
(0.32)\end{array}$ \\
\hline L3 $\Delta$ Euro to US Dollar exchange rate & $\begin{array}{l}0.24 \\
(0.36)\end{array}$ \\
\hline$\Delta$ West European gas Positive & $\begin{array}{l}0.16 \\
(0.16)\end{array}$ \\
\hline L1 $\Delta$ West European gas Positive & $\begin{array}{l}0.23 \\
(0.19)\end{array}$ \\
\hline L2 $\Delta$ West European gas Positive & $\begin{array}{l}0.09 \\
(0.19)\end{array}$ \\
\hline L3 $\Delta$ West European gas Positive & $\begin{array}{l}0.13 \\
(0.21)\end{array}$ \\
\hline$\Delta$ West European gas Negative & $\begin{array}{l}-0.39 \\
(0.42)\end{array}$ \\
\hline L1 $\Delta$ West European gas Negative & $\begin{array}{l}-0.38 \\
(0.25)\end{array}$ \\
\hline L2 $\Delta$ West European gas Negative & $\begin{array}{l}0.81 \\
(0.49)\end{array}$ \\
\hline L3 $\Delta$ West European gas Negative & $\begin{array}{l}-0.29 \\
(0.32)\end{array}$ \\
\hline$\Delta$ Brent Crude Oil UK Close & $\begin{array}{l}-0.04 \\
(0.07)\end{array}$ \\
\hline L1 $\Delta$ Brent Crude Oil UK Close & $\begin{array}{l}-0.04 \\
(0.07)\end{array}$ \\
\hline L2 $\Delta$ Brent Crude Oil UK Close & $\begin{array}{l}0.10 \\
(0.13)\end{array}$ \\
\hline L3 $\Delta$ Brent Crude Oil UK Close & $\begin{array}{l}0.00 \\
(0.08)\end{array}$ \\
\hline Obs. & 73 \\
\hline R-squared & 0.44 \\
\hline F-Test & $1.78 * *$ \\
\hline AIC & -254.54 \\
\hline $\mathrm{BIC}$ & -189.27 \\
\hline
\end{tabular}

Note: White heteroskedasticity-robust standard errors in brackets. ${ }^{*},{ }^{*}$ and $*^{* *}$ show significance at the $10 \%-, 5 \%-$, and $1 \%$-level, respectively. None of the specification tests indicates misspecification. 


\section{Hollow glass (Sector DI2613)}

Table 29 Hollow glass ARDL regression results monthly data (3 lags)

\begin{tabular}{|c|c|}
\hline \multicolumn{2}{|l|}{ Dep. Var.: $\triangle$ Hollow Glass } \\
\hline const & $\begin{array}{l}0.00 * * \\
(0.00)\end{array}$ \\
\hline L1 $\Delta$ Hollow Glass & $\begin{array}{l}0.05 \\
(0.13)\end{array}$ \\
\hline L2 $\Delta$ Hollow Glass & $\begin{array}{l}-0.10 \\
(0.18)\end{array}$ \\
\hline L3 $\Delta$ Hollow Glass & $\begin{array}{l}0.31^{*} \\
(0.17)\end{array}$ \\
\hline$\triangle$ APX Power UK Spot Base Load Index & $\begin{array}{l}-0.00^{*} \\
(0.00)\end{array}$ \\
\hline L1 $\triangle$ APX Power UK Spot Base Load Index & $\begin{array}{l}0.00 \\
(0.00)\end{array}$ \\
\hline L2 $\Delta$ APX Power UK Spot Base Load Index & $\begin{array}{l}-0.00 \\
(0.00)\end{array}$ \\
\hline L3 $\Delta$ APX Power UK Spot Base Load Index & $\begin{array}{l}0.00 \\
(0.00)\end{array}$ \\
\hline$\Delta$ UK Interbank Overnight Middle Rate & $\begin{array}{l}0.01 * * * \\
(0.00)\end{array}$ \\
\hline L1 $\Delta$ UK Interbank Overnight Middle Rate & $\begin{array}{l}0.01 \\
(0.00)\end{array}$ \\
\hline L2 $\Delta$ UK Interbank Overnight Middle Rate & $\begin{array}{l}0.01 \\
(0.00)\end{array}$ \\
\hline L3 $\Delta$ UK Interbank Overnight Middle Rate & $\begin{array}{l}0.00 \\
(0.00)\end{array}$ \\
\hline$\Delta$ US Dollar to British Pound Sterling exchange rate & $\begin{array}{l}0.01 \\
(0.01)\end{array}$ \\
\hline L1 $\Delta$ US Dollar to British Pound Sterling exchange rate & $\begin{array}{l}0.01 \\
(0.02)\end{array}$ \\
\hline L2 $\Delta$ US Dollar to British Pound Sterling exchange rate & $\begin{array}{l}-0.01 \\
(0.01)\end{array}$ \\
\hline L3 $\Delta$ US Dollar to British Pound Sterling exchange rate & $\begin{array}{l}0.02 \\
(0.02)\end{array}$ \\
\hline$\Delta$ Brent Crude Oil UK Close & $\begin{array}{l}0.00 \\
(0.01)\end{array}$ \\
\hline L1 $\Delta$ Brent Crude Oil UK Close & $\begin{array}{l}-0.01^{*} \\
(0.00)\end{array}$ \\
\hline L2 $\Delta$ Brent Crude Oil UK Close & $\begin{array}{l}-0.01 * \\
(0.00)\end{array}$ \\
\hline L3 $\Delta$ Brent Crude Oil UK Close & $\begin{array}{l}-0.00 \\
(0.01)\end{array}$ \\
\hline$\Delta$ UK large consumer gas & $\begin{array}{l}0.01^{*} \\
(0.00)\end{array}$ \\
\hline L1 $\Delta$ UK large consumer gas & $\begin{array}{l}0.00 \\
(0.00)\end{array}$ \\
\hline L2 $\Delta$ UK large consumer gas & $\begin{array}{l}0.00 \\
(0.01)\end{array}$ \\
\hline L3 $\Delta$ UK large consumer gas & $\begin{array}{l}0.00 \\
(0.01)\end{array}$ \\
\hline Obs. & 73 \\
\hline R-squared & 0.43 \\
\hline F-Test & 1.26 \\
\hline AIC & -611.64 \\
\hline $\mathrm{BIC}$ & -556.66 \\
\hline
\end{tabular}

Note: White heteroskedasticity-robust standard errors in brackets. *, ** and *** show significance at the 10\%-, 5\%-, and 1\%-level, respectively. 
Table 30 Hollow glass ARDL regression results monthly data (5 lags)

\begin{tabular}{|c|c|}
\hline \multicolumn{2}{|l|}{ Dep. Var.: $\triangle$ Hollow Glass } \\
\hline const & $\begin{array}{l}0.00 * * \\
(0.00)\end{array}$ \\
\hline L1 $\Delta$ Hollow Glass & $\begin{array}{l}-0.06 \\
(0.18)\end{array}$ \\
\hline L2 $\Delta$ Hollow Glass & $\begin{array}{l}-0.19 \\
(0.17)\end{array}$ \\
\hline L3 $\Delta$ Hollow Glass & $\begin{array}{l}-0.05 \\
(0.26)\end{array}$ \\
\hline L4 $\Delta$ Hollow Glass & $\begin{array}{l}0.03 \\
(0.18)\end{array}$ \\
\hline L5 $\Delta$ Hollow Glass & $\begin{array}{l}-0.10 \\
(0.20)\end{array}$ \\
\hline$\triangle$ APX Power UK Spot Base Load Index & $\begin{array}{l}-0.00 \\
(0.00)\end{array}$ \\
\hline L1 $\Delta$ APX Power UK Spot Base Load Index & $\begin{array}{l}0.00 \\
(0.00)\end{array}$ \\
\hline L2 $\triangle$ APX Power UK Spot Base Load Index & $\begin{array}{l}-0.00 \\
(0.00)\end{array}$ \\
\hline L3 $\Delta$ APX Power UK Spot Base Load Index & $\begin{array}{l}-0.00 \\
(0.00)\end{array}$ \\
\hline L4 $\Delta$ APX Power UK Spot Base Load Index & $\begin{array}{l}-0.00 \\
(0.00)\end{array}$ \\
\hline L5 $\Delta$ APX Power UK Spot Base Load Index & $\begin{array}{l}0.00 \\
(0.00)\end{array}$ \\
\hline$\Delta$ UK Interbank Overnight Middle Rate & $\begin{array}{l}0.01 * * * \\
(0.00)\end{array}$ \\
\hline L1 $\Delta$ UK Interbank Overnight Middle Rate & $\begin{array}{l}0.01 * * * \\
(0.00)\end{array}$ \\
\hline L2 $\Delta$ UK Interbank Overnight Middle Rate & $\begin{array}{l}0.01 * * \\
(0.00)\end{array}$ \\
\hline L3 $\Delta$ UK Interbank Overnight Middle Rate & $\begin{array}{l}0.01 * \\
(0.00)\end{array}$ \\
\hline L4 $\Delta$ UK Interbank Overnight Middle Rate & $\begin{array}{l}0.01 \\
(0.00)\end{array}$ \\
\hline L5 $\Delta$ UK Interbank Overnight Middle Rate & $\begin{array}{l}0.00 \\
(0.00)\end{array}$ \\
\hline$\Delta$ US Dollar to British Pound Sterling exchange rate & $\begin{array}{l}0.01 \\
(0.02)\end{array}$ \\
\hline L1 $\Delta$ US Dollar to British Pound Sterling exchange rate & $\begin{array}{l}0.03 \\
(0.02)\end{array}$ \\
\hline L2 $\Delta$ US Dollar to British Pound Sterling exchange rate & $\begin{array}{l}-0.03 \\
(0.02)\end{array}$ \\
\hline L3 $\Delta$ US Dollar to British Pound Sterling exchange rate & $\begin{array}{l}-0.00 \\
(0.02)\end{array}$ \\
\hline L4 $\Delta$ US Dollar to British Pound Sterling exchange rate & $\begin{array}{l}-0.00 \\
(0.02)\end{array}$ \\
\hline L5 $\Delta$ US Dollar to British Pound Sterling exchange rate & $\begin{array}{l}-0.03 \\
(0.02)\end{array}$ \\
\hline$\Delta$ Brent Crude Oil UK Close & $\begin{array}{l}0.00 \\
(0.01)\end{array}$ \\
\hline L1 $\Delta$ Brent Crude Oil UK Close & $\begin{array}{l}-0.01 * * \\
(0.01)\end{array}$ \\
\hline L2 $\Delta$ Brent Crude Oil UK Close & $\begin{array}{l}-0.01 * \\
(0.01)\end{array}$ \\
\hline L3 $\Delta$ Brent Crude Oil UK Close & $\begin{array}{l}-0.00 \\
(0.01)\end{array}$ \\
\hline L4 $\Delta$ Brent Crude Oil UK Close & $\begin{array}{l}-0.01 \\
(0.01)\end{array}$ \\
\hline L5 $\Delta$ Brent Crude Oil UK Close & $\begin{array}{l}-0.01 \\
(0.01)\end{array}$ \\
\hline$\Delta$ UK large consumer gas & $\begin{array}{l}0.01 \\
(0.01)\end{array}$ \\
\hline L1 $\Delta$ UK large consumer gas & $\begin{array}{l}-0.00 \\
(0.01)\end{array}$ \\
\hline L2 $\Delta$ UK large consumer gas & $\begin{array}{l}-0.00 \\
(0.01)\end{array}$ \\
\hline L3 $\Delta$ UK large consumer gas & $\begin{array}{l}0.00 \\
(0.01)\end{array}$ \\
\hline L4 $\Delta$ UK large consumer gas & $0.01 *$ \\
\hline
\end{tabular}




\begin{tabular}{|l|l|} 
& $(0.00)$ \\
L5 $\Delta$ UK large consumer gas & 0.01 \\
\hline Obs. & $(0.00)$ \\
R-squared & 71 \\
F-Test & 0.56 \\
AIC & 1.09 \\
BIC & -586.03 \\
\hline
\end{tabular}

Note: White heteroskedasticity-robust standard errors in brackets. ${ }^{*}, * *$ and $* * *$ show significance at the $10 \%-, 5 \%-$, and $1 \%$-level, respectively.

Table 31 Hollow glass ARDL regression results monthly data, asymmetry gas (1 lags)

\begin{tabular}{|c|c|}
\hline \multicolumn{2}{|l|}{ Dep. Var.: $\triangle$ Hollow Glass } \\
\hline const & $\begin{array}{l}0.00^{* * *} \\
(0.00)\end{array}$ \\
\hline L1 $\Delta$ Hollow Glass & $\begin{array}{l}0.09 \\
(0.09)\end{array}$ \\
\hline$\Delta$ APX Power UK Spot Base Load Index & $\begin{array}{l}-0.00 * * \\
(0.00)\end{array}$ \\
\hline L1 $\triangle$ APX Power UK Spot Base Load Index & $\begin{array}{l}0.00 \\
(0.00)\end{array}$ \\
\hline$\Delta$ UK Interbank Overnight Middle Rate & $\begin{array}{l}0.00^{*} \\
(0.00)\end{array}$ \\
\hline L1 $\Delta$ UK Interbank Overnight Middle Rate & $\begin{array}{l}0.00 \\
(0.00)\end{array}$ \\
\hline$\Delta$ US Dollar to British Pound Sterling exchange rate & $\begin{array}{l}0.01 \\
(0.02)\end{array}$ \\
\hline L1 $\Delta$ US Dollar to British Pound Sterling exchange rate & $\begin{array}{l}0.02 \\
(0.02)\end{array}$ \\
\hline$\Delta$ Brent Crude Oil UK Close & $\begin{array}{l}0.01 \\
(0.01)\end{array}$ \\
\hline L1 $\Delta$ Brent Crude Oil UK Close & $\begin{array}{l}-0.01 * \\
(0.00)\end{array}$ \\
\hline$\Delta$ UK large consumer gas Positive & $\begin{array}{l}0.01 \\
(0.00)\end{array}$ \\
\hline L1 $\Delta$ UK large consumer gas Positive & $\begin{array}{l}-0.00 \\
(0.00)\end{array}$ \\
\hline$\Delta$ UK large consumer gas Negative & $\begin{array}{l}0.01 \\
(0.00)\end{array}$ \\
\hline L1 $\Delta$ UK large consumer gas Negative & $\begin{array}{l}0.01 \\
(0.01)\end{array}$ \\
\hline Obs. & 75 \\
\hline R-squared & 0.28 \\
\hline F-Test & 1.04 \\
\hline AIC & -633.00 \\
\hline
\end{tabular}

Note: White heteroskedasticity-robust standard errors in brackets. *, ** and *** show significance at the 10\%-, 5\%-, and 1\%-level, respectively. 
Table 32 Hollow glass ARDL regression results monthly data, asymmetry gas (3 lags)

\begin{tabular}{|c|c|}
\hline \multicolumn{2}{|l|}{ Dep. Var.: $\triangle$ Hollow Glass } \\
\hline const & $\begin{array}{l}0.00 \\
(0.00)\end{array}$ \\
\hline L1 $\Delta$ Hollow Glass & $\begin{array}{l}0.08 \\
(0.15)\end{array}$ \\
\hline L2 $\Delta$ Hollow Glass & $\begin{array}{l}-0.11 \\
(0.14)\end{array}$ \\
\hline L3 $\Delta$ Hollow Glass & $\begin{array}{l}0.32 \\
(0.20)\end{array}$ \\
\hline$\triangle$ APX Power UK Spot Base Load Index & $\begin{array}{l}-0.00 \\
(0.00)\end{array}$ \\
\hline L1 $\triangle$ APX Power UK Spot Base Load Index & $\begin{array}{l}-0.00 \\
(0.00)\end{array}$ \\
\hline L2 $\triangle$ APX Power UK Spot Base Load Index & $\begin{array}{l}-0.00 \\
(0.00)\end{array}$ \\
\hline L3 $\triangle$ APX Power UK Spot Base Load Index & $\begin{array}{l}0.00 \\
(0.00)\end{array}$ \\
\hline$\Delta$ UK Interbank Overnight Middle Rate & $\begin{array}{l}0.01 * * * \\
(0.00)\end{array}$ \\
\hline L1 $\Delta$ UK Interbank Overnight Middle Rate & $\begin{array}{l}0.00 \\
(0.00)\end{array}$ \\
\hline L2 $\Delta$ UK Interbank Overnight Middle Rate & $\begin{array}{l}0.01^{*} \\
(0.00)\end{array}$ \\
\hline L3 $\Delta$ UK Interbank Overnight Middle Rate & $\begin{array}{l}0.00 \\
(0.00)\end{array}$ \\
\hline$\Delta$ US Dollar to British Pound Sterling exchange rate & $\begin{array}{l}0.01 \\
(0.01)\end{array}$ \\
\hline L1 $\Delta$ US Dollar to British Pound Sterling exchange rate & $\begin{array}{l}0.01 \\
(0.02)\end{array}$ \\
\hline L2 $\Delta$ US Dollar to British Pound Sterling exchange rate & $\begin{array}{l}-0.02 * * \\
(0.01)\end{array}$ \\
\hline L3 $\Delta$ US Dollar to British Pound Sterling exchange rate & $\begin{array}{l}0.02 \\
(0.01)\end{array}$ \\
\hline$\Delta$ Brent Crude Oil UK Close & $\begin{array}{l}0.00 \\
(0.01)\end{array}$ \\
\hline L1 $\Delta$ Brent Crude Oil UK Close & $\begin{array}{l}-0.01 \\
(0.00)\end{array}$ \\
\hline L2 $\Delta$ Brent Crude Oil UK Close & $\begin{array}{l}-0.00 \\
(0.00)\end{array}$ \\
\hline L3 $\Delta$ Brent Crude Oil UK Close & $\begin{array}{l}-0.00 \\
(0.01)\end{array}$ \\
\hline$\Delta$ UK large consumer gas Positive & $\begin{array}{l}-0.00 \\
(0.01)\end{array}$ \\
\hline L1 $\Delta$ UK large consumer gas Positive & $\begin{array}{l}0.00 \\
(0.01)\end{array}$ \\
\hline L2 $\Delta$ UK large consumer gas Positive & $\begin{array}{l}0.00 \\
(0.01)\end{array}$ \\
\hline L3 $\Delta$ UK large consumer gas Positive & $\begin{array}{l}0.02 * * * \\
(0.01)\end{array}$ \\
\hline$\Delta$ UK large consumer gas Negative & $\begin{array}{l}0.01 \\
(0.01)\end{array}$ \\
\hline L1 $\Delta$ UK large consumer gas Negative & $\begin{array}{l}0.01 \\
(0.01)\end{array}$ \\
\hline L2 $\Delta$ UK large consumer gas Negative & $\begin{array}{l}0.01 \\
(0.01)\end{array}$ \\
\hline L3 $\Delta$ UK large consumer gas Negative & $\begin{array}{l}-0.01 * * \\
(0.00)\end{array}$ \\
\hline Obs. & 73 \\
\hline R-squared & 0.60 \\
\hline F-Test & $4.58 * * *$ \\
\hline AIC & -629.54 \\
\hline $\mathrm{BIC}$ & -565.40 \\
\hline
\end{tabular}

Note: White heteroskedasticity-robust standard errors in brackets. ${ }^{*},{ }^{*}$ and ${ }^{* * *}$ show significance at the $10 \%-, 5 \%-$, and $1 \%-l e v e l$, respectively. 


\section{Container glass}

Table 33 Container glass ARDL regression results monthly data (3 lags)

\begin{tabular}{|c|c|}
\hline \multicolumn{2}{|l|}{ Dep. Var.: $\triangle$ Container Glass } \\
\hline const & $\begin{array}{l}0.01 \\
(0.01)\end{array}$ \\
\hline L1 $\Delta$ Container Glass & $\begin{array}{l}-0.84 * * * \\
(0.14)\end{array}$ \\
\hline L2 $\Delta$ Container Glass & $\begin{array}{l}-0.45^{* * *} \\
(0.16)\end{array}$ \\
\hline L3 $\Delta$ Container Glass & $\begin{array}{l}-0.33^{* *} \\
(0.14)\end{array}$ \\
\hline$\triangle$ APX Power UK Spot Base Load Index & $\begin{array}{l}-0.02 \\
(0.04)\end{array}$ \\
\hline L1 $\triangle$ APX Power UK Spot Base Load Index & $\begin{array}{l}-0.03 \\
(0.05)\end{array}$ \\
\hline L2 $\Delta$ APX Power UK Spot Base Load Index & $\begin{array}{l}0.02 \\
(0.06)\end{array}$ \\
\hline L3 $\Delta$ APX Power UK Spot Base Load Index & $\begin{array}{l}0.03 \\
(0.04)\end{array}$ \\
\hline$\Delta$ UK Interbank Overnight Middle Rate & $\begin{array}{l}0.03 \\
(0.07)\end{array}$ \\
\hline L1 $\Delta$ UK Interbank Overnight Middle Rate & $\begin{array}{l}-0.02 \\
(0.08)\end{array}$ \\
\hline L2 $\Delta$ UK Interbank Overnight Middle Rate & $\begin{array}{l}0.09 \\
(0.08)\end{array}$ \\
\hline L3 $\Delta$ UK Interbank Overnight Middle Rate & $\begin{array}{l}0.11 \\
(0.09)\end{array}$ \\
\hline$\Delta$ US Dollar to British Pound Sterling exchange rate & $\begin{array}{l}0.10 \\
(0.40)\end{array}$ \\
\hline L1 $\Delta$ US Dollar to British Pound Sterling exchange rate & $\begin{array}{l}0.35 \\
(0.41)\end{array}$ \\
\hline L2 $\Delta$ US Dollar to British Pound Sterling exchange rate & $\begin{array}{l}-0.37 \\
(0.41)\end{array}$ \\
\hline L3 $\Delta$ US Dollar to British Pound Sterling exchange rate & $\begin{array}{l}-0.34 \\
(0.50)\end{array}$ \\
\hline$\Delta$ Brent Crude Oil UK Close & $\begin{array}{l}0.06 \\
(0.11)\end{array}$ \\
\hline L1 $\Delta$ Brent Crude Oil UK Close & $\begin{array}{l}-0.22 \\
(0.09)\end{array}$ \\
\hline L2 $\Delta$ Brent Crude Oil UK Close & $\begin{array}{l}-0.05 \\
(0.09)\end{array}$ \\
\hline L3 $\Delta$ Brent Crude Oil UK Close & $\begin{array}{l}-0.11 \\
(0.09)\end{array}$ \\
\hline$\Delta$ UK large consumer gas & $\begin{array}{l}0.04 \\
(0.07)\end{array}$ \\
\hline L1 $\Delta$ UK large consumer gas & $\begin{array}{l}-0.00 \\
(0.07)\end{array}$ \\
\hline L2 $\Delta$ UK large consumer gas & $\begin{array}{l}0.05 \\
(0.08)\end{array}$ \\
\hline L3 $\Delta$ UK large consumer gas & $\begin{array}{l}-0.15 \\
(0.08)\end{array}$ \\
\hline Obs. & 73 \\
\hline R-squared & 0.62 \\
\hline F-Test & $5.99 * * *$ \\
\hline AIC & -164.48 \\
\hline $\mathrm{BIC}$ & -109.51 \\
\hline
\end{tabular}

Note: White heteroskedasticity-robust standard errors in brackets. *, ** and *** show significance at the 10\%-, 5\%-, and 1\%-level, respectively. 
Table 34 Container glass ARDL regression results monthly data (5 lags)

\begin{tabular}{|c|c|}
\hline \multicolumn{2}{|l|}{ Dep. Var.: A Container Glass } \\
\hline Const & $\begin{array}{l}0.01 \\
(0.01)\end{array}$ \\
\hline L1 $\Delta$ Container Glass & $\begin{array}{l}-0.75^{* * *} \\
(0.14)\end{array}$ \\
\hline L2 $\Delta$ Container Glass & $\begin{array}{l}-0.58 * * * \\
(0.18)\end{array}$ \\
\hline L3 $\Delta$ Container Glass & $\begin{array}{l}-0.60 * * * \\
(0.22)\end{array}$ \\
\hline L4 $\Delta$ Container Glass & $\begin{array}{l}-0.47^{*} \\
(0.23)\end{array}$ \\
\hline L5 $\Delta$ Container Glass & $\begin{array}{l}-0.40^{*} \\
(0.20)\end{array}$ \\
\hline$\triangle$ APX Power UK Spot Base Load Index & $\begin{array}{l}-0.04 \\
(0.03)\end{array}$ \\
\hline L1 $\Delta$ APX Power UK Spot Base Load Index & $\begin{array}{l}-0.07 \\
(0.07)\end{array}$ \\
\hline L2 $\triangle$ APX Power UK Spot Base Load Index & $\begin{array}{l}-0.04 \\
(0.08)\end{array}$ \\
\hline L3 $\Delta$ APX Power UK Spot Base Load Index & $\begin{array}{l}0.08 \\
(0.07)\end{array}$ \\
\hline L4 $\Delta$ APX Power UK Spot Base Load Index & $\begin{array}{l}0.09 \\
(0.07)\end{array}$ \\
\hline L5 $\triangle$ APX Power UK Spot Base Load Index & $\begin{array}{l}0.09 \\
(0.05)\end{array}$ \\
\hline$\Delta$ UK Interbank Overnight Middle Rate & $\begin{array}{l}0.13 \\
(0.10)\end{array}$ \\
\hline L1 $\Delta$ UK Interbank Overnight Middle Rate & $\begin{array}{l}0.01 \\
(0.10)\end{array}$ \\
\hline L2 $\Delta$ UK Interbank Overnight Middle Rate & $\begin{array}{l}0.08 \\
(0.08)\end{array}$ \\
\hline L3 $\Delta$ UK Interbank Overnight Middle Rate & $\begin{array}{l}0.14 \\
(0.11)\end{array}$ \\
\hline L4 $\Delta$ UK Interbank Overnight Middle Rate & $\begin{array}{l}0.13 \\
(0.10)\end{array}$ \\
\hline L5 $\Delta$ UK Interbank Overnight Middle Rate & $\begin{array}{l}0.08 \\
(0.08)\end{array}$ \\
\hline$\Delta$ US Dollar to British Pound Sterling exchange rate & $\begin{array}{l}0.67 \\
(0.43)\end{array}$ \\
\hline L1 $\Delta$ US Dollar to British Pound Sterling exchange rate & $\begin{array}{l}0.40 \\
(0.45)\end{array}$ \\
\hline L2 $\Delta$ US Dollar to British Pound Sterling exchange rate & $\begin{array}{l}-0.62 \\
(0.44)\end{array}$ \\
\hline L3 $\Delta$ US Dollar to British Pound Sterling exchange rate & $\begin{array}{l}-0.36 \\
(0.54)\end{array}$ \\
\hline L4 $\Delta$ US Dollar to British Pound Sterling exchange rate & $\begin{array}{l}0.54 \\
(0.43)\end{array}$ \\
\hline L5 $\Delta$ US Dollar to British Pound Sterling exchange rate & $\begin{array}{l}-0.18 \\
(0.46)\end{array}$ \\
\hline$\Delta$ Brent Crude Oil UK Close & $\begin{array}{l}0.05 \\
(0.10)\end{array}$ \\
\hline L1 $\Delta$ Brent Crude Oil UK Close & $\begin{array}{l}-0.26^{* * * *} \\
(0.09)\end{array}$ \\
\hline L2 $\Delta$ Brent Crude Oil UK Close & $\begin{array}{l}0.01 \\
(0.14)\end{array}$ \\
\hline L3 $\Delta$ Brent Crude Oil UK Close & $\begin{array}{l}-0.22 \\
(0.13)\end{array}$ \\
\hline L4 $\Delta$ Brent Crude Oil UK Close & $\begin{array}{l}-0.17 \\
(0.11)\end{array}$ \\
\hline L5 $\Delta$ Brent Crude Oil UK Close & $\begin{array}{l}-0.06 \\
(0.10)\end{array}$ \\
\hline$\Delta$ UK large consumer gas & $\begin{array}{l}-0.00 \\
(0.08)\end{array}$ \\
\hline L1 $\Delta$ UK large consumer gas & $\begin{array}{l}0.02 \\
(0.07)\end{array}$ \\
\hline L2 $\Delta$ UK large consumer gas & $\begin{array}{l}0.08 \\
(0.08)\end{array}$ \\
\hline L3 $\Delta$ UK large consumer gas & $\begin{array}{l}-0.12 \\
(0.10)\end{array}$ \\
\hline L4 $\Delta$ UK large consumer gas & 0.02 \\
\hline
\end{tabular}




\begin{tabular}{|l|l|} 
& $(0.10)$ \\
L5 $\boldsymbol{\Delta}$ UK large consumer gas & $-0.34^{* *}$ \\
\hline Obs. & $(0.16)$ \\
R-squared & 71 \\
F-Test & 0.74 \\
AIC & 4.13 \\
BIC & -160.78 \\
\hline
\end{tabular}

Note: White heteroskedasticity-robust standard errors in brackets. ${ }^{*}, * *$ and $* * *$ show significance at the $10 \%-, 5 \%-$, and $1 \%$-level, respectively.

Table 35 Container glass ARDL regression results monthly data, asymmetry gas (1 lag)

\begin{tabular}{|c|c|}
\hline \multicolumn{2}{|l|}{ Dep. Var.: $\triangle$ Container Glass } \\
\hline const & $\begin{array}{l}-0.00 \\
(0.01)\end{array}$ \\
\hline L1 $\Delta$ Container Glass & $\begin{array}{l}-0.66^{* * *} \\
(0.13)\end{array}$ \\
\hline$\Delta$ APX Power UK Spot Base Load Index & $\begin{array}{l}-0.02 \\
(0.04)\end{array}$ \\
\hline L1 $\Delta$ APX Power UK Spot Base Load Index & $\begin{array}{l}-0.05 \\
(0.04)\end{array}$ \\
\hline$\Delta$ UK Interbank Overnight Middle Rate & $\begin{array}{l}0.06 \\
(0.06)\end{array}$ \\
\hline L1 $\Delta$ UK Interbank Overnight Middle Rate & $\begin{array}{l}-0.06 \\
(0.05)\end{array}$ \\
\hline$\Delta$ US Dollar to British Pound Sterling exchange rate & $\begin{array}{l}0.33 \\
(0.37)\end{array}$ \\
\hline L1 $\Delta$ US Dollar to British Pound Sterling exchange rate & $\begin{array}{l}0.62^{*} \\
(0.33)\end{array}$ \\
\hline$\Delta$ Brent Crude Oil UK Close & $\begin{array}{l}0.08 \\
(0.10)\end{array}$ \\
\hline L1 $\Delta$ Brent Crude Oil UK Close & $\begin{array}{l}-0.12 \\
(0.08)\end{array}$ \\
\hline$\Delta$ UK large consumer gas Positive & $\begin{array}{l}0.05 \\
(0.09)\end{array}$ \\
\hline L1 $\Delta$ UK large consumer gas Positive & $\begin{array}{l}0.00 \\
(0.07)\end{array}$ \\
\hline$\Delta$ UK large consumer gas Negative & $\begin{array}{l}0.14 \\
(0.10)\end{array}$ \\
\hline L1 $\Delta$ UK large consumer gas Negative & $\begin{array}{l}0.01 \\
(0.11)\end{array}$ \\
\hline Obs. & 75 \\
\hline R-squared & 0.48 \\
\hline F-Test & $7.45^{* * *}$ \\
\hline AIC & -169.19 \\
\hline BIC & -136.74 \\
\hline
\end{tabular}

Note: White heteroskedasticity-robust standard errors in brackets. *, ** and *** show significance at the $10 \%$-, 5\%-, and $1 \%$-level, respectively. 
Table 36 Container glass ARDL regression results monthly data, asymmetry gas (3 lags)

\begin{tabular}{|c|c|}
\hline \multicolumn{2}{|l|}{ Dep. Var.: $\triangle$ Container Glass } \\
\hline const & $\begin{array}{l}0.02 \\
(0.02)\end{array}$ \\
\hline L1 $\Delta$ Container Glass & $\begin{array}{l}-0.89 * * * \\
(0.16)\end{array}$ \\
\hline L2 $\Delta$ Container Glass & $\begin{array}{l}-0.49 * * * \\
(0.17)\end{array}$ \\
\hline L3 $\Delta$ Container Glass & $\begin{array}{l}-0.33 * * \\
(0.14)\end{array}$ \\
\hline$\triangle$ APX Power UK Spot Base Load Index & $\begin{array}{l}0.03 \\
(0.06)\end{array}$ \\
\hline L1 $\triangle$ APX Power UK Spot Base Load Index & $\begin{array}{l}0.02 \\
(0.05)\end{array}$ \\
\hline L2 $\triangle$ APX Power UK Spot Base Load Index & $\begin{array}{l}0.04 \\
(0.05)\end{array}$ \\
\hline L3 $\triangle$ APX Power UK Spot Base Load Index & $\begin{array}{l}0.04 \\
(0.04)\end{array}$ \\
\hline$\Delta$ UK Interbank Overnight Middle Rate & $\begin{array}{l}0.07 \\
(0.08)\end{array}$ \\
\hline L1 $\Delta$ UK Interbank Overnight Middle Rate & $\begin{array}{l}0.01 \\
(0.09)\end{array}$ \\
\hline L2 $\Delta$ UK Interbank Overnight Middle Rate & $\begin{array}{l}0.09 \\
(0.08)\end{array}$ \\
\hline L3 $\Delta$ UK Interbank Overnight Middle Rate & $\begin{array}{l}0.14 \\
(0.10)\end{array}$ \\
\hline$\Delta$ US Dollar to British Pound Sterling exchange rate & $\begin{array}{l}0.20 \\
(0.42)\end{array}$ \\
\hline L1 $\Delta$ US Dollar to British Pound Sterling exchange rate & $\begin{array}{l}0.54 \\
(0.34)\end{array}$ \\
\hline L2 $\Delta$ US Dollar to British Pound Sterling exchange rate & $\begin{array}{l}-0.43 \\
(0.38)\end{array}$ \\
\hline L3 $\Delta$ US Dollar to British Pound Sterling exchange rate & $\begin{array}{l}-0.40 \\
(0.51)\end{array}$ \\
\hline$\Delta$ Brent Crude Oil UK Close & $\begin{array}{l}0.04 \\
(0.11)\end{array}$ \\
\hline L1 $\Delta$ Brent Crude Oil UK Close & $\begin{array}{l}-0.28 * * * \\
(0.09)\end{array}$ \\
\hline L2 $\Delta$ Brent Crude Oil UK Close & $\begin{array}{l}-0.05 \\
(0.10)\end{array}$ \\
\hline L3 $\Delta$ Brent Crude Oil UK Close & $\begin{array}{l}-0.10 \\
(0.10)\end{array}$ \\
\hline$\Delta$ UK large consumer gas Positive & $\begin{array}{l}0.04 \\
(0.13)\end{array}$ \\
\hline L1 $\Delta$ UK large consumer gas Positive & $\begin{array}{l}-0.06 \\
(0.11)\end{array}$ \\
\hline L2 $\Delta$ UK large consumer gas Positive & $\begin{array}{l}-0.23 * \\
(0.12)\end{array}$ \\
\hline L3 $\Delta$ UK large consumer gas Positive & $\begin{array}{l}-0.23 \\
(0.21)\end{array}$ \\
\hline$\Delta$ UK large consumer gas Negative & $\begin{array}{l}-0.02 \\
(0.11)\end{array}$ \\
\hline L1 $\Delta$ UK large consumer gas Negative & $\begin{array}{l}-0.02 \\
(0.14)\end{array}$ \\
\hline L2 $\Delta$ UK large consumer gas Negative & $\begin{array}{l}0.24^{*} \\
(0.13)\end{array}$ \\
\hline L3 $\Delta$ UK large consumer gas Negative & $\begin{array}{l}-0.04 \\
(0.10)\end{array}$ \\
\hline Obs. & 73 \\
\hline R-squared & 0.66 \\
\hline F-Test & $7.40 * * *$ \\
\hline AIC & -164.31 \\
\hline $\mathrm{BIC}$ & -100.18 \\
\hline
\end{tabular}

Note: White heteroskedasticity-robust standard errors in brackets. *, ** and *** show significance at the 10\%-, 5\%-, and $1 \%$-level, respectively. 


\section{Ceramic goods (Sector DI262)}

Table 37 Ceramic goods ARDL regression results monthly data (3 lags)

\begin{tabular}{|c|c|}
\hline \multicolumn{2}{|l|}{ Dep. Var.: 4 Ceramic Goods } \\
\hline const & $\begin{array}{l}0.00 \\
(0.00)\end{array}$ \\
\hline L1 $\Delta$ Ceramic Goods & $\begin{array}{l}0.36 * * * \\
(0.12)\end{array}$ \\
\hline L2 $\Delta$ Ceramic Goods & $\begin{array}{l}-0.31 * * \\
(0.14)\end{array}$ \\
\hline L3 $\Delta$ Ceramic Goods & $\begin{array}{l}0.05 \\
(0.07)\end{array}$ \\
\hline$\triangle$ APX Power UK Spot Base Load Index & $\begin{array}{l}-0.01 \\
(0.01)\end{array}$ \\
\hline L1 $\triangle$ APX Power UK Spot Base Load Index & $\begin{array}{l}-0.00 \\
(0.01)\end{array}$ \\
\hline L2 $\triangle$ APX Power UK Spot Base Load Index & $\begin{array}{l}-0.00 \\
(0.01)\end{array}$ \\
\hline L3 $\Delta$ APX Power UK Spot Base Load Index & $\begin{array}{l}-0.01 \\
(0.01)\end{array}$ \\
\hline$\Delta$ UK Interbank Overnight Middle Rate & $\begin{array}{l}0.00 \\
(0.01)\end{array}$ \\
\hline L1 $\Delta$ UK Interbank Overnight Middle Rate & $\begin{array}{l}-0.00 \\
(0.01)\end{array}$ \\
\hline L2 $\Delta$ UK Interbank Overnight Middle Rate & $\begin{array}{l}-0.01 \\
(0.01)\end{array}$ \\
\hline L3 $\Delta$ UK Interbank Overnight Middle Rate & $\begin{array}{l}-0.00 \\
(0.01)\end{array}$ \\
\hline$\Delta$ US Dollar to British Pound Sterling exchange rate & $\begin{array}{l}-0.06 \\
(0.05)\end{array}$ \\
\hline L1 $\Delta$ US Dollar to British Pound Sterling exchange rate & $\begin{array}{l}-0.06 \\
(0.08)\end{array}$ \\
\hline L2 $\Delta$ US Dollar to British Pound Sterling exchange rate & $\begin{array}{l}0.02 \\
(0.06)\end{array}$ \\
\hline L3 $\Delta$ US Dollar to British Pound Sterling exchange rate & $\begin{array}{l}0.03 \\
(0.05)\end{array}$ \\
\hline$\Delta$ Brent Crude Oil UK Close & $\begin{array}{l}-0.02 \\
(0.02)\end{array}$ \\
\hline L1 $\Delta$ Brent Crude Oil UK Close & $\begin{array}{l}-0.01 \\
(0.01)\end{array}$ \\
\hline L2 $\Delta$ Brent Crude Oil UK Close & $\begin{array}{l}-0.00 \\
(0.02)\end{array}$ \\
\hline L3 $\Delta$ Brent Crude Oil UK Close & $\begin{array}{l}0.02 \\
(0.01)\end{array}$ \\
\hline$\Delta \mathrm{UK}$ large consumer gas & $\begin{array}{l}0.09 * * * \\
(0.01)\end{array}$ \\
\hline L1 $\Delta$ UK large consumer gas & $\begin{array}{l}0.05 \\
(0.03)\end{array}$ \\
\hline L2 $\Delta$ UK large consumer gas & $\begin{array}{l}0.04 * * \\
(0.02)\end{array}$ \\
\hline L3 $\Delta$ UK large consumer gas & $\begin{array}{l}-0.01 \\
(0.01) \\
\end{array}$ \\
\hline Obs. & 73 \\
\hline R-squared & 0.72 \\
\hline F-Test & $9.08 * * *$ \\
\hline AIC & -433.40 \\
\hline $\mathrm{BIC}$ & -378.43 \\
\hline
\end{tabular}

Note: White heteroskedasticity-robust standard errors in brackets. *, ** and *** show significance at the 10\%-, 5\%-, and 1\%-level, respectively. 
Table 38 Ceramic goods ARDL regression results monthly data (5 lags)

\begin{tabular}{|c|c|}
\hline \multicolumn{2}{|l|}{ Dep. Var.: $\triangle$ Ceramic Goods } \\
\hline Const & $\begin{array}{l}0.00 \\
(0.00)\end{array}$ \\
\hline L1 $\Delta$ Ceramic Goods & $\begin{array}{l}0.32 * * \\
(0.12)\end{array}$ \\
\hline L2 $\Delta$ Ceramic Goods & $\begin{array}{l}-0.40^{* *} \\
(0.19)\end{array}$ \\
\hline L3 $\Delta$ Ceramic Goods & $\begin{array}{l}-0.05 \\
(0.14)\end{array}$ \\
\hline L4 $\Delta$ Ceramic Goods & $\begin{array}{l}0.03 \\
(0.17)\end{array}$ \\
\hline L5 $\Delta$ Ceramic Goods & $\begin{array}{l}-0.27 * \\
(0.15)\end{array}$ \\
\hline$\triangle$ APX Power UK Spot Base Load Index & $\begin{array}{l}-0.01 \\
(0.01)\end{array}$ \\
\hline L1 $\Delta$ APX Power UK Spot Base Load Index & $\begin{array}{l}-0.01 \\
(0.01)\end{array}$ \\
\hline L2 $\triangle$ APX Power UK Spot Base Load Index & $\begin{array}{l}-0.01 \\
(0.01)\end{array}$ \\
\hline L3 $\Delta$ APX Power UK Spot Base Load Index & $\begin{array}{l}-0.00 \\
(0.01)\end{array}$ \\
\hline L4 $\Delta$ APX Power UK Spot Base Load Index & $\begin{array}{l}0.01 \\
(0.01)\end{array}$ \\
\hline L5 $\Delta$ APX Power UK Spot Base Load Index & $\begin{array}{l}0.01 * \\
(0.01)\end{array}$ \\
\hline$\Delta$ UK Interbank Overnight Middle Rate & $\begin{array}{l}-0.00 \\
(0.01)\end{array}$ \\
\hline L1 $\Delta$ UK Interbank Overnight Middle Rate & $\begin{array}{l}-0.00 \\
(0.01)\end{array}$ \\
\hline L2 $\Delta$ UK Interbank Overnight Middle Rate & $\begin{array}{l}-0.00 \\
(0.01)\end{array}$ \\
\hline L3 $\Delta$ UK Interbank Overnight Middle Rate & $\begin{array}{l}-0.00 \\
(0.02)\end{array}$ \\
\hline L4 $\Delta$ UK Interbank Overnight Middle Rate & $\begin{array}{l}-0.00 \\
(0.01)\end{array}$ \\
\hline L5 $\Delta$ UK Interbank Overnight Middle Rate & $\begin{array}{l}-0.00 \\
(0.01)\end{array}$ \\
\hline$\Delta$ US Dollar to British Pound Sterling exchange rate & $\begin{array}{l}-0.09^{* *} \\
(0.06)\end{array}$ \\
\hline L1 $\Delta$ US Dollar to British Pound Sterling exchange rate & $\begin{array}{l}-0.12 \\
(0.09)\end{array}$ \\
\hline L2 $\Delta$ US Dollar to British Pound Sterling exchange rate & $\begin{array}{l}-0.03 \\
(0.07)\end{array}$ \\
\hline L3 $\Delta$ US Dollar to British Pound Sterling exchange rate & $\begin{array}{l}0.04 \\
(0.05)\end{array}$ \\
\hline L4 $\Delta$ US Dollar to British Pound Sterling exchange rate & $\begin{array}{l}-0.11 \\
(0.07)\end{array}$ \\
\hline L5 $\Delta$ US Dollar to British Pound Sterling exchange rate & $\begin{array}{l}0.00 \\
(0.07)\end{array}$ \\
\hline$\Delta$ Brent Crude Oil UK Close & $\begin{array}{l}-0.02 \\
(0.03)\end{array}$ \\
\hline L1 $\Delta$ Brent Crude Oil UK Close & $\begin{array}{l}-0.00 \\
(0.01)\end{array}$ \\
\hline L2 $\Delta$ Brent Crude Oil UK Close & $\begin{array}{l}0.01 \\
(0.02)\end{array}$ \\
\hline L3 $\Delta$ Brent Crude Oil UK Close & $\begin{array}{l}0.03^{*} \\
(0.02)\end{array}$ \\
\hline L4 $\Delta$ Brent Crude Oil UK Close & $\begin{array}{l}0.01 \\
(0.02)\end{array}$ \\
\hline L5 $\Delta$ Brent Crude Oil UK Close & $\begin{array}{l}0.05 * * \\
(0.02)\end{array}$ \\
\hline$\Delta$ UK large consumer gas & $\begin{array}{l}0.06 * * \\
(0.01)\end{array}$ \\
\hline L1 $\Delta$ UK large consumer gas & $\begin{array}{l}0.04 \\
(0.03)\end{array}$ \\
\hline L2 $\Delta$ UK large consumer gas & $\begin{array}{l}0.05^{* *} \\
(0.02)\end{array}$ \\
\hline L3 $\Delta$ UK large consumer gas & $\begin{array}{l}0.02 \\
(0.02)\end{array}$ \\
\hline L4 $\Delta$ UK large consumer gas & 0.02 \\
\hline
\end{tabular}




\begin{tabular}{|l|l|} 
& $(0.02)$ \\
L5 $\boldsymbol{\Delta}$ UK large consumer gas & 0.00 \\
\hline Obs. & $(0.02)$ \\
R-squared & 71 \\
F-Test & 0.82 \\
AIC & $7.89^{* * *}$ \\
BIC & -426.01 \\
\hline
\end{tabular}

Note: White heteroskedasticity-robust standard errors in brackets. ${ }^{*}, * *$ and $* * *$ show significance at the $10 \%-, 5 \%-$, and $1 \%$-level, respectively.

Table 39 Ceramic goods ARDL regression results monthly data, asymmetry gas (1 lag)

\begin{tabular}{|c|c|}
\hline \multicolumn{2}{|l|}{ Dep. Var.: $\triangle$ Ceramic Goods } \\
\hline const & $\begin{array}{l}-0.00 \\
(0.00)\end{array}$ \\
\hline L1 $\Delta$ Ceramic Goods & $\begin{array}{l}0.26^{* * *} \\
(0.11)\end{array}$ \\
\hline$\Delta$ APX Power UK Spot Base Load Index & $\begin{array}{l}0.01 * * \\
(0.01)\end{array}$ \\
\hline L1 $\Delta$ APX Power UK Spot Base Load Index & $\begin{array}{l}0.01 * \\
(0.00)\end{array}$ \\
\hline$\Delta$ UK Interbank Overnight Middle Rate & $\begin{array}{l}0.01 \\
(0.01)\end{array}$ \\
\hline L1 $\Delta$ UK Interbank Overnight Middle Rate & $\begin{array}{l}0.01 \\
(0.02)\end{array}$ \\
\hline$\Delta$ US Dollar to British Pound Sterling exchange rate & $\begin{array}{l}-0.09 * * \\
(0.04)\end{array}$ \\
\hline L1 $\Delta$ US Dollar to British Pound Sterling exchange rate & $\begin{array}{l}-0.07 \\
(0.06)\end{array}$ \\
\hline$\Delta$ Brent Crude Oil UK Close & $\begin{array}{l}-0.02 \\
(0.01)\end{array}$ \\
\hline L1 $\Delta$ Brent Crude Oil UK Close & $\begin{array}{l}-0.02 \\
(0.01)\end{array}$ \\
\hline$\Delta$ UK large consumer gas Positive & $\begin{array}{l}0.07 * * * \\
(0.01)\end{array}$ \\
\hline L1 $\Delta$ UK large consumer gas Positive & $\begin{array}{l}0.10^{* * *} \\
(0.03)\end{array}$ \\
\hline$\Delta$ UK large consumer gas Negative & $\begin{array}{l}0.06^{* * *} \\
(0.02)\end{array}$ \\
\hline L1 $\Delta$ UK large consumer gas Negative & $\begin{array}{l}-0.02 \\
(0.02)\end{array}$ \\
\hline Obs. & 75 \\
\hline R-squared & 0.71 \\
\hline F-Test & $17.04 * * *$ \\
\hline AIC & -464.29 \\
\hline BIC & -431.84 \\
\hline
\end{tabular}

Note: White heteroskedasticity-robust standard errors in brackets. *, ** and *** show significance at the 10\%-, 5\%-, and 1\%-level, respectively. 
Table 40 Ceramic goods ARDL regression results monthly data, asymmetry gas (3 lags)

\begin{tabular}{|c|c|}
\hline \multicolumn{2}{|l|}{ Dep. Var.: $\triangle$ Ceramic Goods } \\
\hline const & $\begin{array}{l}-0.00 \\
(0.00)\end{array}$ \\
\hline L1 $\Delta$ Ceramic Goods & $\begin{array}{l}0.24^{*} \\
(0.13)\end{array}$ \\
\hline L2 $\Delta$ Ceramic Goods & $\begin{array}{l}-0.33 * * * \\
(0.09)\end{array}$ \\
\hline L3 $\Delta$ Ceramic Goods & $\begin{array}{l}0.02 \\
(0.08)\end{array}$ \\
\hline$\triangle$ APX Power UK Spot Base Load Index & $\begin{array}{l}-0.00 \\
(0.01)\end{array}$ \\
\hline L1 $\Delta$ APX Power UK Spot Base Load Index & $\begin{array}{l}-0.01 \\
(0.01)\end{array}$ \\
\hline L2 $\Delta$ APX Power UK Spot Base Load Index & $\begin{array}{l}-0.01 \\
(0.01)\end{array}$ \\
\hline L3 $\triangle$ APX Power UK Spot Base Load Index & $\begin{array}{l}-0.01 * * \\
(0.01)\end{array}$ \\
\hline$\Delta$ UK Interbank Overnight Middle Rate & $\begin{array}{l}0.01 \\
(0.01)\end{array}$ \\
\hline L1 $\Delta$ UK Interbank Overnight Middle Rate & $\begin{array}{l}0.01 \\
(0.02)\end{array}$ \\
\hline L2 $\Delta$ UK Interbank Overnight Middle Rate & $\begin{array}{l}-0.01 \\
(0.01)\end{array}$ \\
\hline L3 $\Delta$ UK Interbank Overnight Middle Rate & $\begin{array}{l}0.00 \\
(0.01)\end{array}$ \\
\hline$\Delta$ US Dollar to British Pound Sterling exchange rate & $\begin{array}{l}-0.13^{* * *} \\
(0.05)\end{array}$ \\
\hline L1 $\Delta$ US Dollar to British Pound Sterling exchange rate & $\begin{array}{l}-0.07 \\
(0.06)\end{array}$ \\
\hline L2 $\Delta$ US Dollar to British Pound Sterling exchange rate & $\begin{array}{l}0.00 \\
(0.06)\end{array}$ \\
\hline L3 $\Delta$ US Dollar to British Pound Sterling exchange rate & $\begin{array}{l}0.05 \\
(0.05)\end{array}$ \\
\hline$\Delta$ Brent Crude Oil UK Close & $\begin{array}{l}-0.01 \\
(0.02)\end{array}$ \\
\hline L1 $\Delta$ Brent Crude Oil UK Close & $\begin{array}{l}-0.01 \\
(0.01)\end{array}$ \\
\hline L2 $\Delta$ Brent Crude Oil UK Close & $\begin{array}{l}-0.01 \\
(0.01)\end{array}$ \\
\hline L3 $\Delta$ Brent Crude Oil UK Close & $\begin{array}{l}0.01 \\
(0.01)\end{array}$ \\
\hline$\Delta$ UK large consumer gas Positive & $\begin{array}{l}0.09 * * * \\
(0.01)\end{array}$ \\
\hline L1 $\Delta$ UK large consumer gas Positive & $\begin{array}{l}0.13 * * * \\
(0.03)\end{array}$ \\
\hline L2 $\Delta$ UK large consumer gas Positive & $\begin{array}{l}0.08 * * \\
(0.03)\end{array}$ \\
\hline L3 $\Delta$ UK large consumer gas Positive & $\begin{array}{l}0.03 \\
(0.03)\end{array}$ \\
\hline$\Delta$ UK large consumer gas Negative & $\begin{array}{l}0.09 * * * \\
(0.02)\end{array}$ \\
\hline L1 $\Delta$ UK large consumer gas Negative & $\begin{array}{l}-0.01 \\
(0.02)\end{array}$ \\
\hline L2 $\Delta$ UK large consumer gas Negative & $\begin{array}{l}0.02 \\
(0.02)\end{array}$ \\
\hline L3 $\Delta$ UK large consumer gas Negative & $\begin{array}{l}-0.03 * \\
(0.01)\end{array}$ \\
\hline Obs. & 73 \\
\hline R-squared & 0.82 \\
\hline F-Test & $27.07 * * *$ \\
\hline AIC & -462.04 \\
\hline BIC & -397.91 \\
\hline
\end{tabular}

Note: White heteroskedasticity-robust standard errors in brackets. *, ** and *** show significance at the 10\%-, 5\%-, and $1 \%$-level, respectively. 


\section{Ceramic bricks (Non-refractory ceramic building bricks, flooring blocks, supp; sector DI26400)}

Table 41 Ceramic Bricks ARDL regression results monthly data (3 lags)

\begin{tabular}{|c|c|}
\hline \multicolumn{2}{|l|}{ Dep. Var.: A Ceramic Bricks } \\
\hline const & $\begin{array}{l}0.00 * * * \\
(0.00)\end{array}$ \\
\hline L1 $\Delta$ Ceramic Bricks & $\begin{array}{l}-0.35 * * * \\
(0.13)\end{array}$ \\
\hline L2 $\Delta$ Ceramic Bricks & $\begin{array}{l}-0.14 \\
(0.16)\end{array}$ \\
\hline L3 $\Delta$ Ceramic Bricks & $\begin{array}{l}0.02 \\
(0.14)\end{array}$ \\
\hline$\triangle$ APX Power UK Spot Base Load Index & $\begin{array}{l}-0.01 \\
(0.01)\end{array}$ \\
\hline L1 $\Delta$ APX Power UK Spot Base Load Index & $\begin{array}{l}0.00 \\
(0.01)\end{array}$ \\
\hline L2 $\triangle$ APX Power UK Spot Base Load Index & $\begin{array}{l}0.01 \\
(0.01)\end{array}$ \\
\hline L3 $\Delta$ APX Power UK Spot Base Load Index & $\begin{array}{l}0.00 \\
(0.01)\end{array}$ \\
\hline$\Delta$ UK Interbank Overnight Middle Rate & $\begin{array}{l}0.01 \\
(0.01)\end{array}$ \\
\hline L1 $\Delta$ UK Interbank Overnight Middle Rate & $\begin{array}{l}0.00 \\
(0.01)\end{array}$ \\
\hline L2 $\Delta$ UK Interbank Overnight Middle Rate & $\begin{array}{l}-0.01 \\
(0.01)\end{array}$ \\
\hline L3 $\Delta$ UK Interbank Overnight Middle Rate & $\begin{array}{l}-0.01 \\
(0.01)\end{array}$ \\
\hline$\Delta$ US Dollar to British Pound Sterling exchange rate & $\begin{array}{l}0.02 \\
(0.06)\end{array}$ \\
\hline L1 $\Delta$ US Dollar to British Pound Sterling exchange rate & $\begin{array}{l}0.07 \\
(0.07)\end{array}$ \\
\hline L2 $\Delta$ US Dollar to British Pound Sterling exchange rate & $\begin{array}{l}0.04 \\
(0.06)\end{array}$ \\
\hline L3 $\Delta$ US Dollar to British Pound Sterling exchange rate & $\begin{array}{l}0.03 \\
(0.06)\end{array}$ \\
\hline$\Delta$ Brent Crude Oil UK Close & $\begin{array}{l}0.02 \\
(0.01)\end{array}$ \\
\hline L1 $\Delta$ Brent Crude Oil UK Close & $\begin{array}{l}0.00 \\
(0.01)\end{array}$ \\
\hline L2 $\Delta$ Brent Crude Oil UK Close & $\begin{array}{l}0.01 \\
(0.01)\end{array}$ \\
\hline L3 $\Delta$ Brent Crude Oil UK Close & $\begin{array}{l}0.00 \\
(0.01)\end{array}$ \\
\hline$\Delta$ UK large consumer gas & $\begin{array}{l}-0.00 \\
(0.01)\end{array}$ \\
\hline L1 $\Delta$ UK large consumer gas & $\begin{array}{l}0.02 * \\
(0.01)\end{array}$ \\
\hline L2 $\Delta$ UK large consumer gas & $\begin{array}{l}0.02 \\
(0.01)\end{array}$ \\
\hline L3 $\Delta$ UK large consumer gas & $\begin{array}{l}0.01 \\
(0.02)\end{array}$ \\
\hline Obs. & 73 \\
\hline R-squared & 0.32 \\
\hline F-Test & $1.79 * *$ \\
\hline AIC & -444.48 \\
\hline $\mathrm{BIC}$ & -389.51 \\
\hline
\end{tabular}

Note: White heteroskedasticity-robust standard errors in brackets. *, ** and *** show significance at the 10\%-, 5\%-, and $1 \%$-level, respectively. None of the specification tests indicates misspecification. 
Table 42 Ceramic Bricks ARDL regression results monthly data (5 lags)

\begin{tabular}{|c|c|}
\hline \multicolumn{2}{|l|}{ Dep. Var.: A Ceramic Bricks } \\
\hline Const & $\begin{array}{l}0.01 * * \\
(0.00)\end{array}$ \\
\hline L1 $\Delta$ Ceramic Bricks & $\begin{array}{l}-0.39^{* *} \\
(0.15)\end{array}$ \\
\hline L2 $\Delta$ Ceramic Bricks & $\begin{array}{l}-0.29 \\
(0.21)\end{array}$ \\
\hline L3 $\Delta$ Ceramic Bricks & $\begin{array}{l}-0.13 \\
(0.20)\end{array}$ \\
\hline L4 $\Delta$ Ceramic Bricks & $\begin{array}{l}-0.32 * \\
(0.18)\end{array}$ \\
\hline L5 $\Delta$ Ceramic Bricks & $\begin{array}{l}-0.03 \\
(0.21)\end{array}$ \\
\hline$\triangle$ APX Power UK Spot Base Load Index & $\begin{array}{l}-0.01 \\
(0.01)\end{array}$ \\
\hline L1 $\Delta$ APX Power UK Spot Base Load Index & $\begin{array}{l}0.01 \\
(0.01)\end{array}$ \\
\hline L2 $\triangle$ APX Power UK Spot Base Load Index & $\begin{array}{l}0.01 \\
(0.01)\end{array}$ \\
\hline L3 $\Delta$ APX Power UK Spot Base Load Index & $\begin{array}{l}0.00 \\
(0.01)\end{array}$ \\
\hline L4 $\Delta$ APX Power UK Spot Base Load Index & $\begin{array}{l}0.01 \\
(0.01)\end{array}$ \\
\hline L5 $\triangle$ APX Power UK Spot Base Load Index & $\begin{array}{l}0.00 \\
(0.01)\end{array}$ \\
\hline$\Delta$ UK Interbank Overnight Middle Rate & $\begin{array}{l}0.01 \\
(0.01)\end{array}$ \\
\hline L1 $\Delta$ UK Interbank Overnight Middle Rate & $\begin{array}{l}-0.00 \\
(0.01)\end{array}$ \\
\hline L2 $\Delta$ UK Interbank Overnight Middle Rate & $\begin{array}{l}-0.01 \\
(0.02)\end{array}$ \\
\hline L3 $\Delta$ UK Interbank Overnight Middle Rate & $\begin{array}{l}-0.00 \\
(0.02)\end{array}$ \\
\hline L4 $\Delta$ UK Interbank Overnight Middle Rate & $\begin{array}{l}0.01 \\
(0.01)\end{array}$ \\
\hline L5 $\Delta$ UK Interbank Overnight Middle Rate & $\begin{array}{l}0.02 \\
(0.01)\end{array}$ \\
\hline$\Delta$ US Dollar to British Pound Sterling exchange rate & $\begin{array}{l}0.02 \\
(0.07)\end{array}$ \\
\hline L1 $\Delta$ US Dollar to British Pound Sterling exchange rate & $\begin{array}{l}0.08 \\
(0.08)\end{array}$ \\
\hline L2 $\Delta$ US Dollar to British Pound Sterling exchange rate & $\begin{array}{l}0.01 \\
(0.06)\end{array}$ \\
\hline L3 $\Delta$ US Dollar to British Pound Sterling exchange rate & $\begin{array}{l}0.07 \\
(0.08)\end{array}$ \\
\hline L4 $\Delta$ US Dollar to British Pound Sterling exchange rate & $\begin{array}{l}-0.05 \\
(0.07)\end{array}$ \\
\hline L5 $\Delta$ US Dollar to British Pound Sterling exchange rate & $\begin{array}{l}0.12^{*} \\
(0.06)\end{array}$ \\
\hline$\Delta$ Brent Crude Oil UK Close & $\begin{array}{l}0.02 \\
(0.01)\end{array}$ \\
\hline L1 $\Delta$ Brent Crude Oil UK Close & $\begin{array}{l}-0.00 \\
(0.02)\end{array}$ \\
\hline L2 $\Delta$ Brent Crude Oil UK Close & $\begin{array}{l}0.01 \\
(0.02)\end{array}$ \\
\hline L3 $\Delta$ Brent Crude Oil UK Close & $\begin{array}{l}-0.01 \\
(0.02)\end{array}$ \\
\hline L4 $\Delta$ Brent Crude Oil UK Close & $\begin{array}{l}-0.01 \\
(0.02)\end{array}$ \\
\hline L5 $\Delta$ Brent Crude Oil UK Close & $\begin{array}{l}-0.01 \\
(0.02)\end{array}$ \\
\hline$\Delta$ UK large consumer gas & $\begin{array}{l}-0.00 \\
(0.02)\end{array}$ \\
\hline L1 $\Delta$ UK large consumer gas & $\begin{array}{l}0.01 \\
(0.01)\end{array}$ \\
\hline L2 $\Delta$ UK large consumer gas & $\begin{array}{l}0.02 \\
(0.01)\end{array}$ \\
\hline L3 $\Delta$ UK large consumer gas & $\begin{array}{l}0.00 \\
(0.02)\end{array}$ \\
\hline L4 $\Delta$ UK large consumer gas & -0.00 \\
\hline
\end{tabular}




\begin{tabular}{|l|l|} 
& $(0.02)$ \\
L5 $\boldsymbol{\Delta}$ UK large consumer gas & 0.02 \\
\hline Obs. & $(0.02)$ \\
R-squared & 71 \\
F-Test & 0.50 \\
AIC & $2.38^{* * *}$ \\
BIC & -427.15 \\
\hline
\end{tabular}

Note: White heteroskedasticity-robust standard errors in brackets. ${ }^{*},{ }^{*}$ and ${ }^{* * *}$ show significance at the $10 \%-, 5 \%-$, and $1 \%$-level, respectively. None of the specification tests indicates misspecification.

Table 43 Ceramic Bricks ARDL regression results monthly data, asymmetry gas (1 lag)

\begin{tabular}{|c|c|}
\hline \multicolumn{2}{|l|}{ Dep. Var.: A Ceramic Bricks } \\
\hline const & $\begin{array}{l}0.00 * * \\
(0.00)\end{array}$ \\
\hline L1 $\Delta$ Ceramic Bricks & $\begin{array}{l}-0.28 * * \\
(0.11)\end{array}$ \\
\hline$\triangle$ APX Power UK Spot Base Load Index & $\begin{array}{l}0.01 \\
(0.01)\end{array}$ \\
\hline L1 $\triangle$ APX Power UK Spot Base Load Index & $\begin{array}{l}0.00 \\
(0.00)\end{array}$ \\
\hline$\Delta$ UK Interbank Overnight Middle Rate & $\begin{array}{l}0.02 * * \\
(0.01)\end{array}$ \\
\hline L1 $\Delta$ UK Interbank Overnight Middle Rate & $\begin{array}{l}0.01 * \\
(0.01)\end{array}$ \\
\hline$\Delta$ US Dollar to British Pound Sterling exchange rate & $\begin{array}{l}0.03 \\
(0.05)\end{array}$ \\
\hline L1 $\Delta$ US Dollar to British Pound Sterling exchange rate & $\begin{array}{l}0.05 \\
(0.06)\end{array}$ \\
\hline$\Delta$ Brent Crude Oil UK Close & $\begin{array}{l}0.01 \\
(0.01)\end{array}$ \\
\hline L1 $\Delta$ Brent Crude Oil UK Close & $\begin{array}{l}-0.01 \\
(0.01)\end{array}$ \\
\hline$\Delta$ UK large consumer gas Positive & $\begin{array}{l}0.01 \\
(0.01)\end{array}$ \\
\hline L1 $\Delta$ UK large consumer gas Positive & $\begin{array}{l}0.02 * \\
(0.01)\end{array}$ \\
\hline$\Delta$ UK large consumer gas Negative & $\begin{array}{l}-0.01 \\
(0.02)\end{array}$ \\
\hline L1 $\Delta$ UK large consumer gas Negative & $\begin{array}{l}0.00 \\
(0.01)\end{array}$ \\
\hline Obs. & 75 \\
\hline R-squared & 0.27 \\
\hline F-Test & $1.84^{*}$ \\
\hline AIC & -471.45 \\
\hline $\mathrm{BIC}$ & -439.00 \\
\hline
\end{tabular}

Note: White heteroskedasticity-robust standard errors in brackets. *, ** and *** show significance at the 10\%-, 5\%-, and 1\%-level, respectively. None of the specification tests indicates misspecification. 
Table 44 Ceramic Bricks ARDL regression results monthly data, asymmetry gas (3 lags)

\begin{tabular}{|c|c|}
\hline \multicolumn{2}{|l|}{ Dep. Var.: A Ceramic Bricks } \\
\hline const & $\begin{array}{l}0.00 * * \\
(0.00)\end{array}$ \\
\hline L1 $\Delta$ Ceramic Bricks & $\begin{array}{l}-0.25^{* *} \\
(0.14)\end{array}$ \\
\hline L2 $\Delta$ Ceramic Bricks & $\begin{array}{l}-0.06 \\
(0.12)\end{array}$ \\
\hline L3 $\Delta$ Ceramic Bricks & $\begin{array}{l}-0.13 \\
(0.14)\end{array}$ \\
\hline$\triangle$ APX Power UK Spot Base Load Index & $\begin{array}{l}0.00 \\
(0.01)\end{array}$ \\
\hline L1 $\triangle$ APX Power UK Spot Base Load Index & $\begin{array}{l}0.00 \\
(0.01)\end{array}$ \\
\hline L2 $\triangle$ APX Power UK Spot Base Load Index & $\begin{array}{l}0.00 \\
(0.01)\end{array}$ \\
\hline L3 $\triangle$ APX Power UK Spot Base Load Index & $\begin{array}{l}0.01 \\
(0.01)\end{array}$ \\
\hline$\Delta$ UK Interbank Overnight Middle Rate & $\begin{array}{l}0.02 * \\
(0.01)\end{array}$ \\
\hline L1 $\Delta$ UK Interbank Overnight Middle Rate & $\begin{array}{l}-0.00 \\
(0.01)\end{array}$ \\
\hline L2 $\Delta$ UK Interbank Overnight Middle Rate & $\begin{array}{l}-0.01 \\
(0.01)\end{array}$ \\
\hline L3 $\Delta$ UK Interbank Overnight Middle Rate & $\begin{array}{l}0.00 \\
(0.01)\end{array}$ \\
\hline$\Delta$ US Dollar to British Pound Sterling exchange rate & $\begin{array}{l}0.05 \\
(0.06)\end{array}$ \\
\hline L1 $\Delta$ US Dollar to British Pound Sterling exchange rate & $\begin{array}{l}0.06 \\
(0.06)\end{array}$ \\
\hline L2 $\Delta$ US Dollar to British Pound Sterling exchange rate & $\begin{array}{l}-0.02 \\
(0.05)\end{array}$ \\
\hline L3 $\Delta$ US Dollar to British Pound Sterling exchange rate & $\begin{array}{l}0.04 \\
(0.06)\end{array}$ \\
\hline$\Delta$ Brent Crude Oil UK Close & $\begin{array}{l}0.02 \\
(0.01)\end{array}$ \\
\hline L1 $\Delta$ Brent Crude Oil UK Close & $\begin{array}{l}-0.00 \\
(0.01)\end{array}$ \\
\hline L2 $\Delta$ Brent Crude Oil UK Close & $\begin{array}{l}0.02 \\
(0.01)\end{array}$ \\
\hline L3 $\Delta$ Brent Crude Oil UK Close & $\begin{array}{l}-0.00 \\
(0.01)\end{array}$ \\
\hline$\Delta$ UK large consumer gas Positive & $\begin{array}{l}-0.02 \\
(0.02)\end{array}$ \\
\hline L1 $\Delta$ UK large consumer gas Positive & $\begin{array}{l}0.02 * \\
(0.01)\end{array}$ \\
\hline L2 $\Delta$ UK large consumer gas Positive & $\begin{array}{l}-0.03 \\
(0.03)\end{array}$ \\
\hline L3 $\Delta$ UK large consumer gas Positive & $\begin{array}{l}0.06 * * * \\
(0.02)\end{array}$ \\
\hline$\Delta$ UK large consumer gas Negative & $\begin{array}{l}-0.01 \\
(0.03)\end{array}$ \\
\hline L1 $\Delta$ UK large consumer gas Negative & $\begin{array}{l}0.01 \\
(0.02)\end{array}$ \\
\hline L2 $\Delta$ UK large consumer gas Negative & $\begin{array}{l}0.06 * * * \\
(0.01)\end{array}$ \\
\hline L3 $\Delta$ UK large consumer gas Negative & $\begin{array}{l}-0.03 * \\
(0.03)\end{array}$ \\
\hline Obs. & 73 \\
\hline R-squared & 0.51 \\
\hline F-Test & $2.69 * * *$ \\
\hline AIC & -461.21 \\
\hline $\mathrm{BIC}$ & -397.07 \\
\hline
\end{tabular}

Note: White heteroskedasticity-robust standard errors in brackets. ${ }^{*},{ }^{*}$ and $*^{* *}$ show significance at the $10 \%-, 5 \%-$, and $1 \%$-level, respectively. None of the specification tests indicates misspecification. 


\section{Glossary}

AIC

Akaike's

Information

Criterion

ARDL

Asymmetric Price Transmission

Autoregressive

Distributed Lag

Model

Bayesian Schwarz

Information

Criterion

BIC

British Thermal

Unit

BTU

CGE Model

Chemical

Industries

Association

CIA

Cointegration see Akaike's Information Criterion

Akaike's Information Criterion (AIC) is a measure of the goodness of fit of an estimated statistical model.

see Autoregressive Distributed Lag Model

In this context, the phenomenon of asymmetric price transmission is referred to the following observation: Producers immediately pass through cost increases to the consumers, but cost decreases are passed through only with delay, if at all. Hence, asymmetric price transmission is directly related to the ability of producers to differently pass on positive and negative input price shocks to the consumers.

Autoregression is simply a regression model that relates the time series variable to its past values. If independent variables and their lags are added to the autoregression, we call this an autoregressive distributed lag model.

In statistics, the Bayesian Schwarz Information Criterion (BIC) is a criterion for model selection among a class of parametric models with different numbers of parameters.

see Bayesian Schwarz Information Criterion

The British thermal unit (BTU) is a unit of energy, A BTU is defined as amount of heat required to raise the temperature of one imperial pound of liquid water by one degree from $60^{\circ}$ to $61^{\circ} \mathrm{Fahrenheit} \mathrm{at} \mathrm{a} \mathrm{constant}$ pressure of one atmosphere.

see British Thermal Unit

see Computable General Equilibrium Model

The Chemical Industries Association (CIA) is a organisation that represents chemical and pharmaceutical businesses throughout the UK

see Chemical Industries Association

Cointegration is an econometric property of time series variables. If two or more series are themselves non-stationary, but a linear combination of them is stationary, then the series are said to be cointegrated. 
Computable

General

Equilibrium

Model

Cost Pass-Through Ability

EU Allowance

EU Emissions Trading Scheme

EU ETS

EUA

Grandfathering

LDPE

Low-Density

Polyethylene

Menu Costs

UK Interbank

Overnight Middle

Rate
Computable General Equilibrium (CGE) models are a class of economic model that use actual economic data to estimate how an economy might react to changes in policy, technology or other external factors.

The cost pass-through ability is the capability of firms to adjust the output price of a good, if the prices of inputs needed to produce the good change.

EU Emission Allowances (EUAs) are issued to installations which have a cap on their emissions under the EU Emissions Trading Scheme (EU ETS). An installation must hold and surrender EU Allowances and/or project based carbon credits equal to its monitored carbon dioxide emissions by the annual EU ETS reconciliation date. EU Allowances are also the main unit which is traded in the EU ETS. One EU Emission Allowance $=1 \mathrm{t} \mathrm{CO} 2 \mathrm{e}(\mathrm{CO} 2$ equivalent $)$

The European Union's Emissions Trading Scheme (EU ETS) commenced operation in January 2005 as a mechanism of the Kyoto Protocol. The first phase of the scheme ran from 2005-2007. The second trading phase runs from 2008-2012, coinciding with the Kyoto Protocol commitment period. Next to EU Allowances (EUAs), Kyoto flexible mechanism certificates (Certified Emission Reductions and Emission Reduction Units) are accepted as compliance tools within the EU ETS.

see EU Emissions Trading Scheme

see EU Allowance

In the context of the European Union's Emissions Trading Scheme (EU ETS), grandfathering signifies that the EU Emission Allowances (EUAs) are handed to the installations under the EU ETS for free. A different approach would be to auction the (EUAs).

see Low Density Polyethylene

Low-Density Polyethylene (LDPE) is a thermoplastic made from naphtha.

In economics, menu costs are transaction costs firms face when prices change in an economy, for example for updating price lists or brochures. Because this transaction cost exists, firms sometimes do not change their prices even though their input costs have changed, therefore menu costs can lead to price stickiness.

In the context of this study, the UK Interbank Overnight Middle Rate represents a proxy for the prevailing interest rate in the economy. 
Unit Root Test A unit root test tests whether a time series variable is non-stationary using an autoregressive model. The most famous test is the augmented Dickey-Fuller test, which uses the existence of a unit root as the null hypothesis.

White Test The White Test is an econometric test that establishes whether the residual variance of a variable in a regression model is constant, i.e. if there is homoscedasticity. 